\title{
ATYPICAL LOCALIZATION OF EPH-RTKS IN CHILDHOOD CANCER RHABDOMYOSARCOMA
}

\author{
A Dissertation
}

Presented to

The Faculty of the Graduate School

At the University of Missouri

In Partial Fulfillment

Of the Requirements for the Degree

Doctor of Philosophy

\author{
By \\ Ronnie Marie LaCombe \\ Division of Biological Sciences \\ D.D.W. Cornelison, Dissertation Mentor
}

MAY 2019 
The undersigned, appointed by the dean of the Graduate School, have examined the dissertation entitled

\title{
ATYPICAL LOCALIZATION OF EPH-RTKS IN CHILDHOOD CANCER RHABDOMYOSARCOMA
}

\author{
Presented by Ronnie LaCombe, \\ a candidate for the degree of Doctor of Philosophy, \\ and hereby certify that, in their opinion, it is worthy of acceptance.
}

Dr. DDW Cornelison

Dr. Stephen Alexander

Dr. Paula McSteen

Dr. Jeffrey Bryan 


\section{ACKNOWLEDGEMENTS}

A large reason that I chose to pursue my $\mathrm{PhD}$ at the University of Missouri in the Division of Biological Sciences was because of the supportive culture I observed during graduate school interviews. This observation proved true by the huge amount of support I have received while here. First and foremost, I would like to thank Dr. D Cornelison, my $\mathrm{PhD}$ advisor, for seeing my potential and allowing me to tackle a risky project for my graduate research. While the road has not been entirely smooth, her guidance and expertise helped me to survive the hard times of $\mathrm{PhD}$ research and come out the other side as a stronger person and scientist.

I would also like to thank my committee members Dr. Stephen Alexander, Dr. Paula McSteen, and Dr. Jeffrey Bryan. All of you have helped me develop professionally, scientifically, and personally by helping me with my research, nominating me for leadership opportunities, and providing support. Thank you for all your help during graduate school.

I have had the opportunity to work with many talented colleagues in lab and would like to extend a special thanks to Dr. Laura Arnold, Dr. Danny Stark, Dr. Robert Arpke, Dr. Alessandra Cecchini, and Alexandra Diller. All of you provided immeasurable help in lab from troubleshooting experiments to proofreading many emails, documents, and application materials. I have learned so much from all of you and will never forget the laughs, dry-ice bomb wars, ice-cream outings, and encouragement I received. You were in the trenches of graduate school beside me and helped keep me up!

I also want to thank Debbie Allen, Dr. Mark Hannink, Dr. Lori Eggert, Dr. Anand Chandrasekhar, Dr. Kathy Newton, Nila Emerich, Rebecca Ballew, Dr. Robin Walker, 
and Loriana Sekarski for all of the support, advice, and resources you provided me to succeed in and out of lab. All of you have been sounding boards for me and eager to help me make my seemingly crazy ideas reality. Thank you for encouraging my creative side during my scientific training!

I would not have survived graduate school without the continual support of my parents, Ron and Joanmarie LaCombe. Between day visits, pet sitting, rides to the airport, and vacations you have helped me celebrate my successes and move past my failures. My siblings, Jake, Scott, and Katie LaCombe have all provided a shoulder to lean on and an ear to vent to when graduate school felt too overwhelming. I would be remiss if I did not acknowledge my cat Esmerelda. I adopted her three months into graduate school, so she has been with me from the very beginning. Having a pet that is excited to see you every day was very comforting and gave me reason to take a break and go home when work started to take over.

Finally, I would like to thank my friends, in particular Ellee Cook, Jenna Lee, Jacob Loesche, Mike Mueller, Jake Burkhart, Marco Navarro, Arianne Messerman, Levi Storks, Emi Asante, Austin Lynn, and Paul Petrowski for keeping me sane and making me be social when all I wanted to do was stay-in and be alone. They say it takes a village to raise a child, but it also takes one to get a $\mathrm{PhD}$. 


\section{TABLE OF CONTENTS}

ACKNOWLEDGEMENTS.............................................................ii

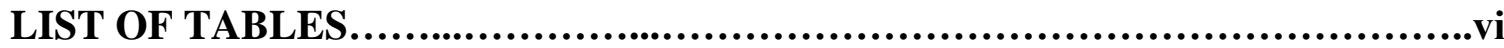

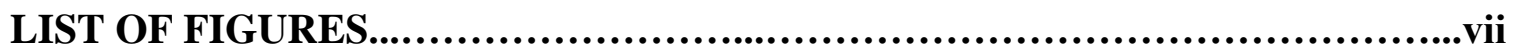

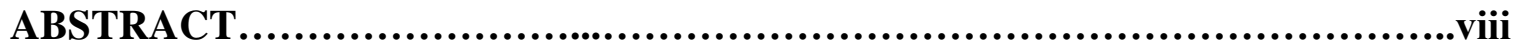

CHAPTER 1 • Rhabdomyosarcoma and Eph and ephrin signaling: a review

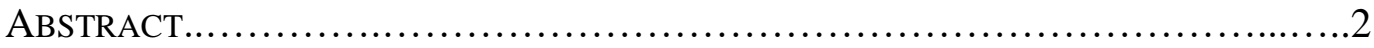

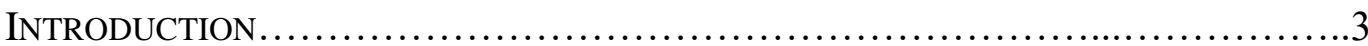

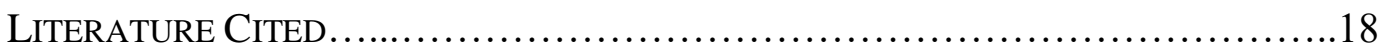

CHAPTER 2 • Eph and ephrin Expression in Mouse and Canine Rhabdomyosarcoma

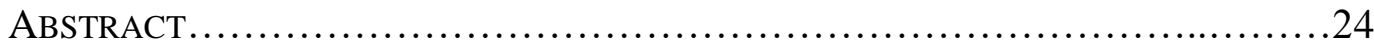

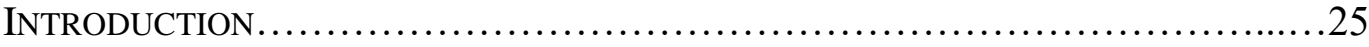

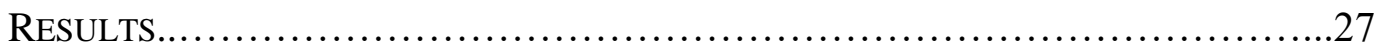

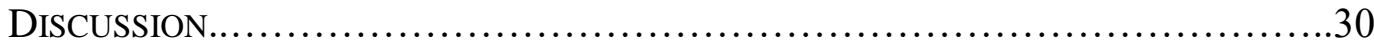

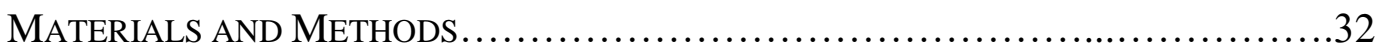

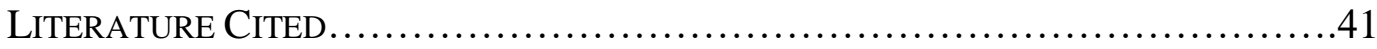

CHAPTER 3 - Atypical localization of EphA1 in Rhabdomyosarcoma

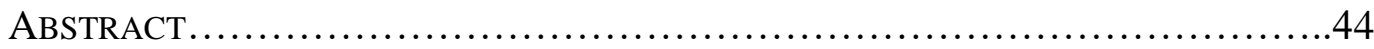

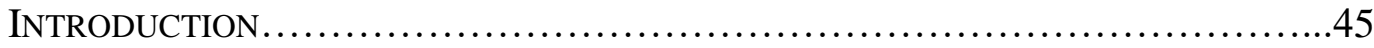

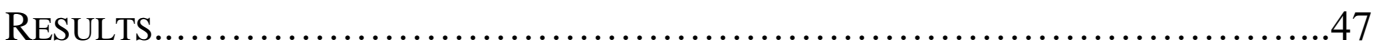

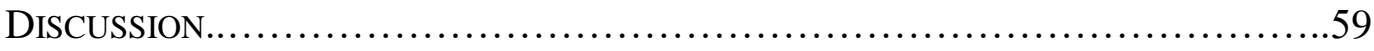

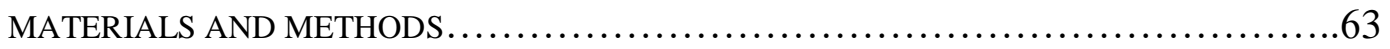


LITERATURE CITED.

CHAPTER 4 • EphA7 and Syndecan-4 Involvement in Rhabdomyosarcoma

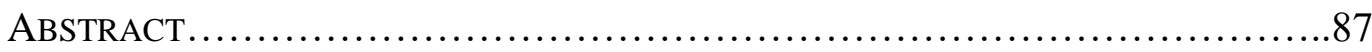

INTRODUCTION ............................................................ 88

RESULTS........................................................... 90

DISCUSSION......................................................... 93

MATERIAL AND METHODS................................................... 95

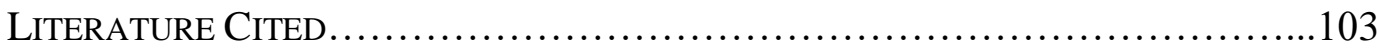

\section{CHAPTER 5 • Concluding Remarks and Future Directions}

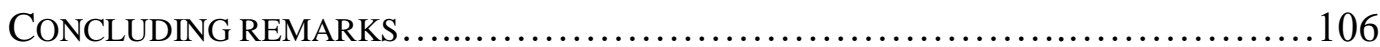

LiTERATURE CiTED.................................................... 111

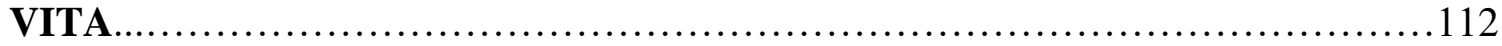




\section{LIST OF TABLES}

\section{Chapter 2.}

Table 2-1. Eph and ephrin mRNA and protein expression in mouse RMS and

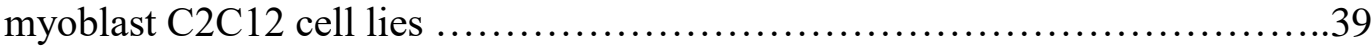

Table 2-2. Eph and ephrin protein expression in mouse primary satellite cells, canine tumor sections, and mouse RMS cell lines.........................40

\section{Chapter 3.}

Table 3-1. Receptor tyrosine kinases in the nucleus............................74 


\section{LIST OF FIGURES}

\section{Chapter 1.}

Figure 1-1. Removal of activated RTKs from the plasma membrane.............15

Figure 1-2. Eph and ephrin binding..........................................

Figure 1-3. EphB4 Signaling in RMS.................................. 17

\section{Chapter 2.}

Figure 2-1. Eph and ephrin protein expression in primary canine RMS tumors....35

Figure 2-2. Eph and ephrin mRNA expression in mouse RMS cell lines.........37

Figure 2-3. Eph and ephrin protein expression in mouse RMS cell liens..........38

\section{Chapter 3.}

Figure 3-1. EphA1 is expressed in the nucleus of canine RMS tumors...........76

Figure 3-2. EphA1 is in the nucleus of mouse and human RMS cell lines.........77

Figure 3-3. EphA1 is differentially localized in distinct phases of the cell cycle

Figure 3-4. EphA1 is in the nucleus of mouse RMS cell lines as a full-length polypeptide that might be phosphorylated.................................... 80

Figure 3-5. Isolated EphA1 from mouse RMS cell lysates.......................82

Figure 3-6. Inducing expression of EphA1-myc-His............................

\section{Chapter 4.}

Figure 4-1. RMS cell growth in response to EphA7 treatment...................99

Figure 4-2. Cell cycle analysis of RMS cells treated with EphA7 ..............100

Figure 4-3. Mouse RMS cell lines express satellite cell marker Syndedcan-4...101

Figure 4-4. Syndecan-4 is in the nucleus after lipid-raft disruption..............102 


\title{
Atypical Localization of Eph-RTKs in Childhood Cancer \\ Rhabdomyosarcoma
}

\begin{abstract}
Rhabdomyosarcoma (RMS), the most common soft tissue tumor in children, is an aggressive cancer with a 5-year survival rate of $24 \%$ if it has metastasized. Current treatment options are limited to surgery, chemotherapy and radiation, so there is a significant unmet need for targeted therapies. Eph receptor tyrosine kinases have been implicated in the development and progression of many other tumor types. Recent results from our group identified several Eph receptors expressed by primary muscle stem cells (satellite cells), which led us to screen for protein expression of Ephs in canine RMS primary tumors as well as mouse and human RMS cell lines. Intriguingly, we noted strong expression but abnormal localization of one Eph receptor: in multiple tumors from all three species, we detected EphA1 in the nucleus of interphase cells. Mislocalization of RTKs to the nucleus in other tumor types has been shown to promote cancer progression, with the classic case being ErbBs. There are only two published studies about Ephs localizing to the nucleus and to date no other nuclear RTKs have been identified in RMS. These data represent the first case of a nuclear RTK in RMS, and the first time that EphA1 has been detected in the nucleus of any cell type.
\end{abstract}




\title{
Chapter 1:
}

\section{Rhabdomyosarcoma and Eph and ephrin signaling: a review}

\author{
Ronnie LaCombe ${ }^{1}$ and DDW Cornelison ${ }^{1,2}$
}

\footnotetext{
${ }^{1}$ Division of Biological Sciences and Bond Life Sciences Center, University of Missouri, Columbia, MO

2 to whom correspondence should be addressed
} 


\section{Abstract}

Rhabdomyosarcoma (RMS), the most common soft tissue tumor in children, is an aggressive cancer in which more than half of diagnoses are in children under the age of 10. If the RMS has metastasized, 5-year survival rates are as low as $24 \%$. This is largely because there is no FDA approved targeted therapy for RMS; instead, a combination of chemotherapy, radiation, and surgery are used. These treatments are often insufficient because they fail to differentiate between proliferating cancer cells and healthy cells, resulting in severe side effects of treatment. A key group of proteins that are targets for drug development are receptor tyrosine kinases (RTKs). 18 drugs inhibiting RTK signaling are FDA approved cancer treatments, but none specifically target Eph receptors, which are the largest family of RTKs in humans. This chapter will describe the molecular aberrations that lead to RMS and introduce Eph and ephrin signaling in cancer and development, then focuses on the current information about Eph and ephrin involvement in RMS and how this dissertation will expand upon this knowledge and introduce a new axis for Eph signaling from locations other than the plasma membrane. 


\section{Rhabdomyosarcoma.}

Rhabdomyosarcoma (RMS) is a childhood cancer that accounts for nearly half of all childhood soft tissue tumors [1]. There are about 350 new cases a year, more than half of which are children under the age of 10. RMS has an overall 5-year survival rate of $61.8 \%$, making it an aggressive cancer. In cases where the cancer has already spread to distant sites, the survival rates drop to $24 \%$ [2, 3]. Treatment for both types of RMS depends on how far the cancer has progressed, but often involves surgery, chemotherapy, and radiation. While these treatments work for some patients, they are inadequate for others. Some tumors are unresectable due to their location, and chemotherapy and radiation treatment have severe side effects as they kill all proliferating cells regardless of if they are healthy or tumor cells. Unfortunately, there are no targeted therapies for RMS yet, so identification of a druggable target is of high interest and importance.

The National Cancer Institute defines RMS as a cancer that forms from striated muscle and can occur anywhere in the body, but most often occurs initially in the head and neck region, urogenital tract, and limbs. Histologically, RMS resembles immature skeletal muscle, with morphologies ranging from small round cells that resemble muscle precursors to elongated, multinucleate cells that resemble differentiating myotubes $[4,5]$. RMS cells also share similarities with developing skeletal muscle at the molecular level. Expression of the myogenic transcription factors MyoD and Myogenin is used as a diagnostic marker for RMS; in normal muscle tissue myogenin expression is limited to terminally postmitotic myocytes, however it can be expressed in proliferating RMS cells indicating a dysregulation of the myogenic program $[6,7]$. 
There are two main subtypes of RMS which were named based on their distinctive cell morphologies - embryonal (ERMS) and alveolar (ARMS). ERMS cells resemble undifferentiated myoblasts or embryonic myotubes [5]. ERMS accounts for $75 \%$ of RMS cases, and occurs most commonly in the head and neck regions [1]. It is the less-aggressive type, with 5-year survival rates of 73.4\% [2]. ARMS is more common in older children and teenagers, and is the more aggressive type, with 5-year survival rates of $47.8 \%$ [2]. ARMS most commonly initiates in the extremities, but metastatic tumors can be found anywhere. The two subtypes are also characterized by distinct genetic alterations. ERMS typically has many somatic mutations, but most often includes loss of heterozygosity on chromosome 11, with preferential loss of the maternal allele. This region, $11 \mathrm{p} 15$, contains at least three tumor suppressor genes $[8,9]$. It also contains Insulin-like Growth Factor 2 (IGF2), which is usually expressed from the paternally inherited allele due to imprinting [10]. Because the maternal allele is lost in RMS, expression of IGF2 is maintained and even elevated, causing it to act like an oncogene [11]. Other mutations that are often associated with ERMS occur in PTCH1, TP53, and genes encoding proteins involved in the Ras pathway [9]. Unlike ERMS, ARMS tumors have often experienced a translocation of chromosomes 2 or 1 and chromosome 13 that creates a novel functional transcription factor fusing the PAX3 or PAX7 DNA binding domain, respectively, to the FOXO1 transactivation domain with few or no additional tumor-promoting genetic mutations [12-14]. 77\% of ARMS cases are fusion positive, with the PAX3:FOXO1 fusion occurring more often than the PAX7:FOXO1 fusion [15]. Expression of the fusion protein is thought to contribute to ARMS by stimulating 
proliferation, promoting cell survival by avoiding apoptosis, and suppressing terminal differentiation [16-18].

RMS is classified as a skeletal muscle tumor based on its histological appearance and expression of muscle regulatory factors. This is a rare occurrence because mature muscle is composed mostly of terminally differentiated muscle fibers and quiescent satellite cells [19]. Without actively proliferating cells, it is less likely for cancer causing mutations to accumulate. This might explain why RMS is more common in children than adults. From birth through puberty, cells throughout the body are growing at faster rates than in adulthood. This rapid expansion increases the chances of a cell accumulating enough cancer-causing mutations to result in RMS. In addition to a lower likelihood of cancer forming due to the low proliferation rate, skeletal muscle has cancer inhibitory properties as well. Conditioned media from primary cultures of rat muscle cells specifically inhibits tumor cell growth by reducing proliferation rates [20, 21]. The causative factor was identified as a small-molecule that weighs about 500 Daltons that is resistant to high temperatures and protease treatment, indicating that it is likely not a protein $[20,21]$. Not only do muscle cells secrete an anti-tumor factor, they may also have intrinsic anti-tumor properties themselves. Melanoma or lung cancer cells cocultured with myogenic cells acquire muscle-like phenotypes and eventually fuse to muscle cells, losing their tumor properties [22]. This myogenic conversion following fusion to myogenic cells also occurs in vivo also [22]. The low intrinsic rates of proliferation in muscle, the presence of a secreted anti-tumor factor, and the ability to convert and fuse tumor cells to muscle cells combine to reduce the likelihood that a cancer will arise from skeletal muscle, possibly accounting for the uniqueness of RMS. 
Even though it is considered a skeletal muscle cancer, the cell-of-origin for RMS has not been identified. Some groups argue that satellite cells are the origin because RMS expresses many myogenic genes [23, 24]. However, RMS can occur where there is no skeletal muscle, and therefore likely would be void of satellite cells from which RMS could develop. Other proposed cells of origin include endothelial cells, mesenchymal cells, and fetal myoblasts [25-27]. There is also evidence that ARMS and ERMS might arise from different cell types, and that the identity of the cell origin might have therapeutic implications [28]. RMS tumors formed when the Pax3:Foxol translocation was expressed in prenatal myogenic progenitors and myoblasts as well as in postnatal satellite cells. Expression of Pax3:Foxo1 in satellite cells gave rise to ERMS instead of ARMS and was due to lower levels of Pax3:Foxol resulting from epigenetic differences in the prenatal and postnatal lineages. Treatment of cells from tumors originating from the prenatal myoblast lineage with the histone deacetylase inhibitor etinostat reduced mRNA levels of Pax3:Foxol and reduced tumor growth rates. This suggests that origin of the tumor has an influence on Pax3:Foxo1 expression and that this can be modified pharmacologically to convert aggressive, fusion-positive RMS to a state similar to fusionnegative RMS that has more favorable prognosis [28].

\section{$\underline{\text { Receptor Tyrosine Kinases and Eph-ephrin signaling }}$}

Receptor tyrosine kinases (RTKs) are typically single-pass transmembrane proteins responsible for responding to external stimuli by initiating internal signaling cascades and transmitting information about the external environment into the cell; they are currently classified in 20 families including EGFRs, PDGFRs, FGFRs, and VEGFRs [29]. They initiate a diverse array of cellular responses including proliferation, 
differentiation, migration, and survival [30-33]. The ligands that activate RTKs can originate in distant sites, such as endocrine signaling through hormones, or from adjacent cells in juxtacrine signaling that involves cell-to-cell contact [34, 35]. Upon ligand binding, RTKs form either homo- or heterodimers which promotes transautophosphorylation of the intracellular kinase domains and allows interactions with adaptor proteins and intracellular signal transduction machinery [29, 36, 37]. To downregulate activated RTK signaling, receptors are removed from the cell surface through clathrin-mediated endocytosis [38, 39]. The endosomal lumen has a lower $\mathrm{pH}$, which promotes dissociation of the ligand [29]. After dissociation, the deactivated RTK can be recycled to the plasma membrane or targeted for degradation (Figure 1-1) $[29,40$, $41]$.

The Eph receptor family is the largest receptor tyrosine kinase (RTK) family in vertebrates. There are 14 members divided into two classes - EphA receptors (EphA1-8 and EphA10) and EphB receptors (EphB1-4 and EphB6) - which are categorized based on affinity for the two subclasses of membrane-bound ligands: ephrinAs and ephrinBs [35]. The ephrinAs (ephrinA1-5) are tethered by a glycosylphosphatidlyinositol (GPI) anchor while ephrinBs (ephrinB1-3) are transmembrane proteins [42]. Together, Ephs and ephrins constitute a bidirectional signaling system involved in contact-dependent cell-to-cell communication that can signal into the receptor (forward) and ligand (reverse) bearing cell, or in both directions at the same time [43]. Receptor-ligand binding is context-dependent and highly promiscuous: the EphAs bind to most or all of the ephrinAs, and the EphBs bind to most or all of the ephrinBs (Figure 1-2) [35, 44]. In addition, EphA4 and EphB2 are capable of binding across classes [35]. 
Eph-ephrin signaling occurs in a multitude of cellular contexts in most tissues of the body, including during vascular development, cell sorting for boundary formation in structures such as somites and rhombomeres, axon guidance, bone development, and stem cell regulation [45-47]. While Ephs and ephrins have strong binding affinities for each other, they also participate in signaling cascades by cross-talk with other transmembrane proteins such as integrins, cadherins, CXCR-4, FGFR, and VEGFR [48, 49]. Eph activation can result in the activation of downstream signaling pathways such as the MAPK, PI3K, and Rho-family GTPases to affect proliferation, adhesion, and cytoskeleton dynamics, respectively (reviewed in [45]). Signaling through Ephs and ephrins can also cause a multitude of downstream effects depending on cellular context and the expression of other transmembrane proteins [50]. For example, ephrinB2 reverse signaling is required for vascular formation and angiogenesis, but has also been implicated in vascular pruning through inducing apoptosis in endothelial cells [47, 51, 52]. Given the variety of mechanisms Eph-ephrin signaling, it is necessary to understand the cellular context in order to interpret understand how they are involved in a particular cells or tissues.

\section{Eph and ephrin signaling in development and stem cells}

Eph and ephrin signaling affects many aspects of development, including cell segregation and boundary formation, axon guidance, cell migration, vascular remodeling, and control of stem cell niches [53,54]. Cell segregation and boundary formation are necessary for somite formation, a process in which Eph and ephrin signaling is required [55]. During somitogenesis in the paraxial mesoderm, populations of Eph-expressing 
cells and ephrin-expressing cells segregate away from each other and sequentially express EphA2 or ephrinB2, creating distinct boundaries at the edges of somites [56, 57]. Cells at the edges of the boundaries undergo a mesenchymal-to-epithelial transition followed by rostrocaudal patterning of somites [57, 58]. Eph receptors and ephrin ligands are again expressed in exclusive, sequential patterns with ephrinB1 expressed on the caudal side while EphB3 is expressed on the rostral side [59]. These distinct regions direct migration of EphB3 positive neural crest cells through the rostral half of the somite as they interact repulsively with ephrinB1 [59].

Eph and ephrin signaling in development is also involved in directing migration of axons to innervate the correct targets [60]. Most retinal ganglion cell (RGC) axons cross the midline at the optic chiasm to reach the superior colliculus, a region in the midbrain [61]. A fraction of RGC axons will not cross the optic chiasm and will remain on the same side of the midline as the RGC bodies, a process important to animals with binocular vision [61]. Interactions between EphB1 and ephrinB2 direct the crossing of axons through the optic chiasm. RGCs that do not express EphB1 cross the ephrinB2positive optic chiasm, while RGCs that do express EphB1 are directed away from the chiasm due to repulsive interactions between EphB2 and ephrinB2 [62]. In addition to RGCs, spinal motor axons are directed to innervate limb muscles through Eph and ephrin signaling. Once directed to the correct location, Ephs and ephrins also help axons innervate the appropriate target. In skeletal muscle, ephrinA3 is expressed specifically on slow muscle fibers while EphA8 is expressed at neuromuscular junctions on fast myofibers [63]. The repulsive interactions of EphA8 and ephrinA3 determine if a 
myofiber will be innervated with fast or slow motor neurons, thus determining if a fiber will be a slow or fast myofiber [63].

Eph and ephrin signaling controls many stem cell niches and forward and reverse signaling may have opposing roles. Frequently, forward signaling (to the Eph-expressing cell) is associated with proliferation and reverse signaling (to the ephrin-expressing cell) with differentiation [64]. The best-characterized activity of Eph/ephrin signaling is in stem cell niches in the intestine. Stem cells of the intestinal epithelium reside in the bottom of crypts. As the epithelium of the intestine turns over, new cells are produced from these stem cells and differentiate as they move up the walls of the crypt towards to the lumen $[64,65]$. Opposing EphB and ephrinB expression gradients drive this process, maintaining the separation of EphB2/EphB3-positive stem cells in the crypts and ephrinB1/ephrinB2-positive differentiated cells near the lumen [54]. The subventricular zone of the brain, EphA7 is expressed on ependymal cells and astrocytes where it negatively regulates proliferation of neuroblasts through ephrinA2 reverse signaling [66].

\section{Eph and ephrin signaling in cancer}

Signaling molecules with necessary and sufficient functions during development and stem cell maintenance such as RTKs are often dysregulated in cancer, with mechanisms ranging from overexpression to defective deactivation [67, 68]. Of the 58 RTKs in the human genome, 48 have been identified as oncogenes and 30 of those are necessary for tumor formation in various cancers [69]. Due to the high percentage of RTKs that are intimately involved in cancer formation and progression, they represent 
promising targets for antitumor drug development [70, 71]. There are 39 known RTK inhibitors, 18 of which have already been approved by the FDA for cancer treatment [69]. As Ephs are the largest family of RTKs in humans and are expressed in most tissues and throughout development, it is unsurprising to find that they have wellcharacterized roles in a number of cancers including breast cancer, prostate cancer, lung cancer, and melanoma [72]. Their dysregulated expression can promote cancer formation, progression, and metastasis, or combinations thereof: Ephs and ephrins regulate tumor cell proliferation, invasion, epithelial-to-meshenchymal transition, angiogenesis, and renewal of cancer stem cells (reviewed in $[43,72,73]$ ). Some of these functions occur independent of ligand stimulation via Eph cross-talk with other transmembrane proteins $[45,74]$.

Interestingly, ligand-dependent signaling often has tumor-suppressive effects while ligand-independent signaling has tumor-promoting effects [75, 76]. Mammary tumor cell proliferation is controlled by EphA2 ligand-independent signaling, indicated by high-expression levels of minimally phosphorylated receptor [77]. When forward signaling is initiated by ephrinA1 or an activating antibody, Ras-MAPK activation of proliferation was inhibited [78]. By preventing EphA2 forward signaling in this context, proliferation rates are not able to be attenuated, aiding in uncontrolled expansion of cells resulting in tumor initiation or growth. As a tumor continues to grow, it must be infiltrated by blood vessels to maintain a steady supply of oxygen and other nutrients to continue growing. EphB4 and ephrinB2 are upregulated under low-oxygen, hypoxic conditions that would signal a need for new blood vessel formation [79]. New vessels are 
formed through EphB4 activating ephrinB2 reverse signaling which leads to angiogenesis by promoting endothelial cell invasion and survival [80].

\section{Eph and ephrin signaling in Rhabdomyosarcoma}

Despite Ephs being the largest RTK family in humans, their role in rhabdomyosarcoma is not well described. Their involvement in RMS was only discovered a decade ago, when EphB and ephrinB expression levels were shown to be altered in both ERMS and RRMS cell lines and primary tumors compared to normal skeletal muscle [81]. In RMS cell lines, EphB2, EphB3, EphB4, and ephrinB1 were upregulated while EphB2 and ephrinB2 were downregulated. All of the EphBs and ephrinBs were upregulated in the primary tumors to varying degrees. Expression was not found to be subtype specific, and a functional role was not associated with EphB/ephrinB dysregulation [81].

EphA3, on the other hand, is expressed only in RMS cell lines that were negative for the PAX:FOXO1 translocation and is the only EphA that is differentially expressed [82]. PAX:FOXO1 negative cells were stimulated with ephrinA5-Fc, a chimeric protein fusing ephrinA5 to an immunoglobulin Fc domain, to activate EphA3, which caused decreased adhesion to fibronectin as well as decreased directional migration through activation of Rho GTPase. Translocation positive RMS tends to be a more aggressive cancer that metastasizes more often than translocation negative RMS. EphA3 expression may decrease the metastatic potential of translocation negative cells by inhibiting their migratory potential, while its expression may be suppressed in translocation positive cells to avoid the migratory suppression caused by receptor activation [82]. 
While EphA3 is expressed in ERMS and translocation negative cells, EphB4 was identified in an RNAi screen to identify factors modulating cell viability in ARMS [83]. Knockdown of EphB4 significantly reduced cell viability of murine ARMS cell lines. Furthermore, its role in cell viability appears to be mediated through ligand-independent signaling. Instead, it interacts with PDGFR $\beta$ to stimulate cell survival and proliferation pathways. Ligand-dependent signaling by stimulation with ephrinB2 led to apoptosis, demonstrating that distinct signaling pathways are activated through EphB4 liganddependent or ligand-independent signaling (Figure 1-3). Furthermore, this study demonstrated that oncogenic signaling by PDGFR $\beta$ and EphB4 could be blocked with the tyrosine kinase inhibitor dasatinib [83].

Two small molecules targeting EphB4 signaling have recently been tested in preclinical trials [84]. VasG3 is an anti-EphB4 inhibitory antibody; it did not affect ARMS growth or survival in xenograft models [84]. A fusion protein of soluble EphB4 with either mouse or human serum albumin (MSA or HSA, respectively) was also used to disrupt ephrinB2/EphB4 signaling; this slightly reduced ARMS tumor growth but had no effect on ERMS tumor progression. Conclusions drawn from these trials were that neither the VasG3 antibody nor the soluble EphB4 to inhibit EphB4 signaling constitute viable therapeutic solutions [84].

\section{Filling in the gap of Eph and ephrin signaling in RMS}

Eph and ephrins are involved in cancer formation and progression and play a pivotal role development and stem cell proliferation and differentiation decisions, but there is still much to learn. Only 2 of the 14 Eph receptors in humans have described 
roles in RMS, thus this could represent a significant gap in our understanding of RMS cell biology and signaling mechanisms. Investigating Eph and ephrin involvement in RMS formation or progression could uncover novel avenues for drug design or cancer treatment. Due to their complex signaling nature (bidirectional signaling, promiscuous receptor-ligand binding, interactions with other proteins, etc.) it is important to examine Eph and ephrin signaling in the specific context of interest, in this case RMS.

Chapter 2 of this dissertation will describe Eph and ephrin expression in canine and mouse RMS. By using a multi-species approach, we can identify Ephs and ephrins that are more likely to play a role in RMS progression or development, as any abnormality in expression conserved between the two species is likely to be significant. In Chapter 3 I will characterize an atypical expression pattern that was found in both species and compare it to expression in human RMS. Then, in Chapter 4 I will describe preliminary findings suggesting EphA7 may slow RMS cell growth and that RMS cells express a satellite cell marker, providing evidence that supports the satellite cell as a RMS cell-of-origin. Finally, Chapter 5 will conclude this dissertation and I will discuss implications for this body of work as well as technical problems that were encountered. 


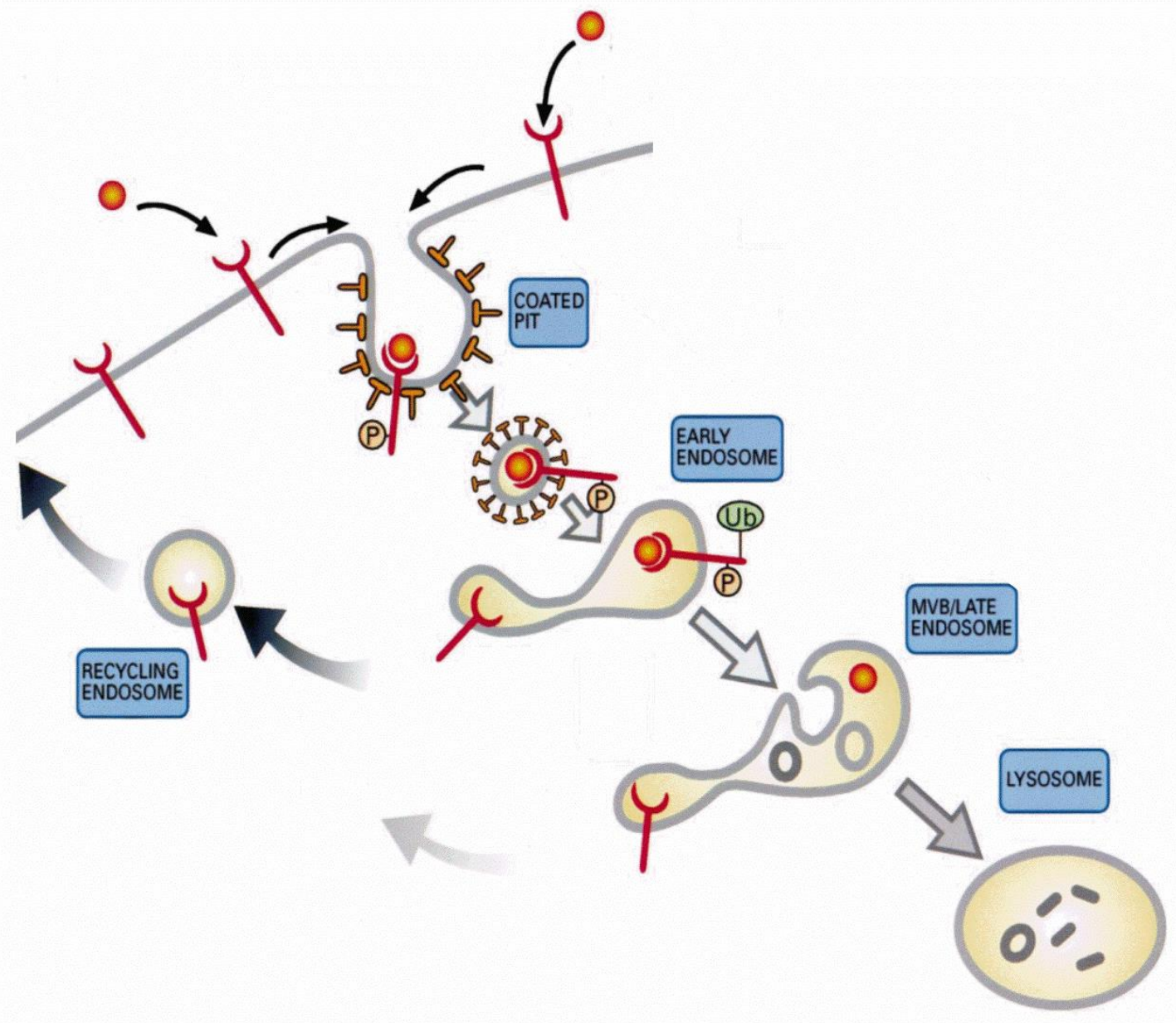

Figure 1-1. Removal of activated RTKs from the plasma membrane.

Activated RTKs are removed from the plasma membrane by clathrin-mediated endocytosis. The activating ligand is dissociated in endosomes. The deactivated RTK is then either recycled back to the plasma membrane or sent to the lysosome for degradation. Figure adapted from [40]. 


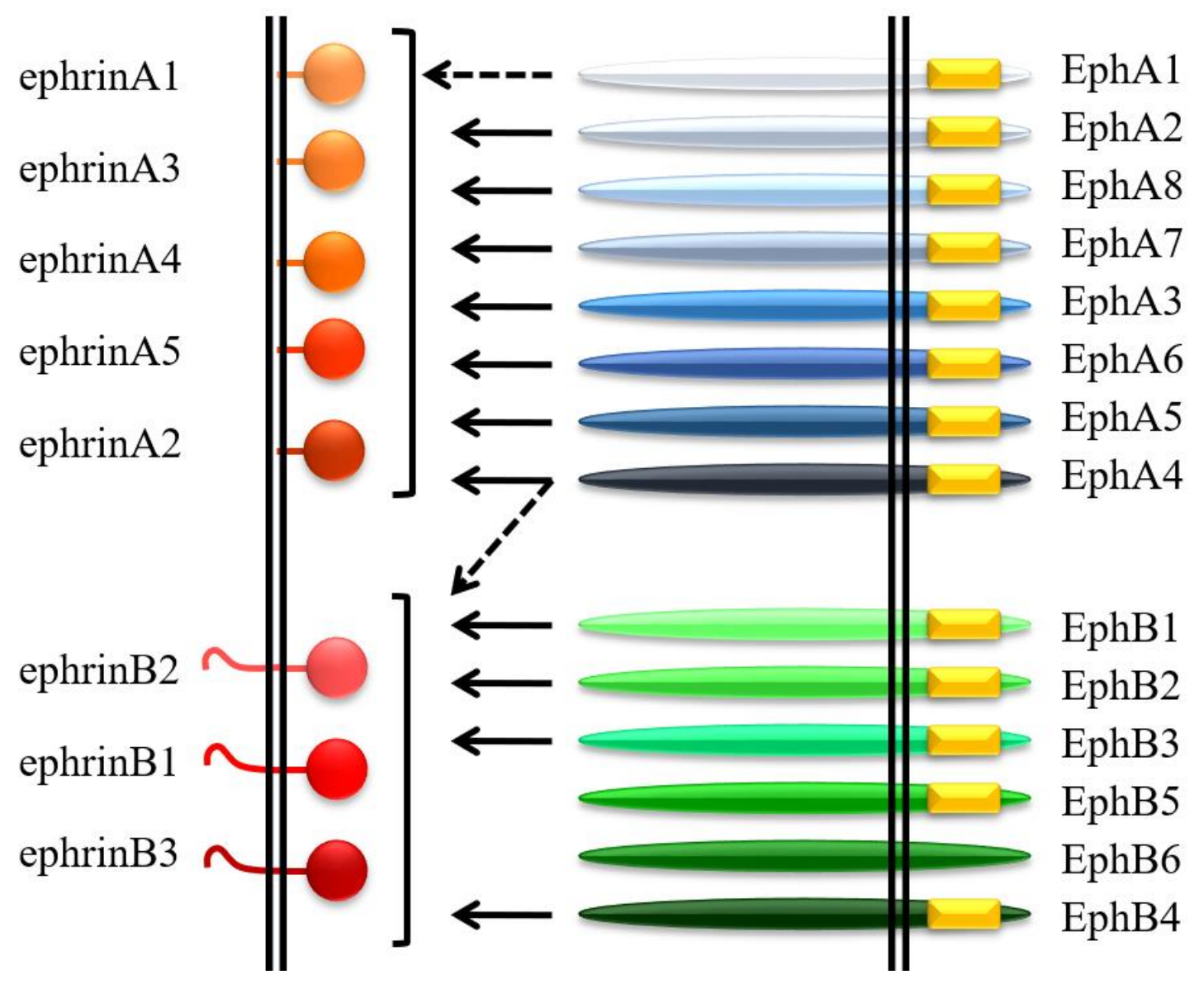

Figure 1-2. Eph and ephrin binding.

Eph receptor tyrosine kinases are divided into two classes (A and B) based on their binding affinity for either GPI-tethered ephrinA ligands or transmembrane ephrinB ligands. EphAs can bind to any ephrinA, but the only EphA that can bind an ephrinB is EphA4. EphBs can bind to any ephrinB, but not to ephrinAs. EphA1 is the only Eph receptor that has high affinity for one ligand, ephrinA1. Yellow boxes indicate functional kinase domain. Figure adapted from Frisen et al 1999 [35]. 
PDGF-BB

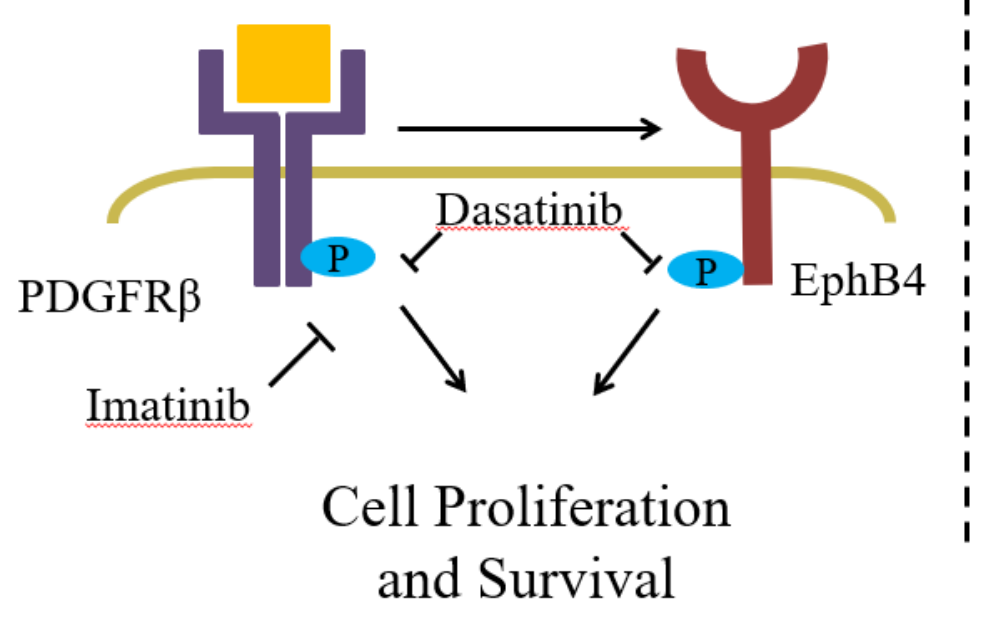

ephrinB2

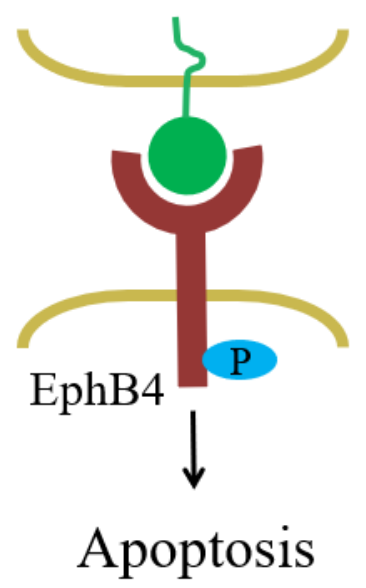

Figure 1-3. EphB4 Signaling in RMS.

EphB4 forward signaling has distinct ligand-dependent and ligand-independent functions. When activated with ephrinB2, EphB4 signaling leads to cell death through apoptosis.

Ligand-independent signaling is mediated through cross-talk with PDGF-BB and initiates cell proliferation and survival. These functions are attenuated by small molecule treatment targeting just PDGF-BB (Imatinib) or targeting PDGF-BB and EphB4 (Dasatinib). Figure adapted from Aslam et. al. 2014 [83]. 


\section{Literature Cited}

1. Gurney, J.G., et al., Soft Tissue Sarcomas, in Cancer Incidence and Survival among Children and Adolescents: United States SEER Program 1975-1995, L. Ries, et al., Editors. 1999, NIH Pub: Bethesda, MD. p. 111-123.

2. Ognjanovic, S., et al., Trends in childhood rhabdomyosarcoma incidence and survival in the United States, 1975-2005. Cancer, 2009. 115(18): p. 4218-26.

3. Perez, E.A., et al., Rhabdomyosarcoma in children: a SEER population based study. J Surg Res, 2011. 170(2): p. e243-51.

4. Stuart, A. and J. Radhakrishnan, Rhabdomyosarcoma. Indian Journal of Pediatrics, 2004. 71(4): p. 331-337.

5. Caserto, B.G., A comparative review of canine and human rhabdomyosarcoma with emphasis on classification and pathogenesis. Vet Pathol, 2013. 50(5): p. 806-26.

6. Cessna, M.H., et al., Are Myogenin and MyoD1 Expression Specific for Rhabdomyosarcoma? A Study of 150 Cases, With Emphasis on Spindle Cell Mimics. The American Journal of Surgical Pathology. 25(9): p. 1150-1157.

7. Kumar, S., et al., Myogenin is a Specific Marker for Rhabdomyosarcoma: An Immunohistochemical Study in Paraffin-Embedded Tissues. Modern Pathology, 2000. 13(9): p. 988-993.

8. $\quad$ Loh, W.E., et al., Human chromosome 11 contains two different growth suppressor genes for embryonal rhabdomyosarcoma. Proc Natl Acad Sci U S A, 1992. 89: p. 1755-1759.

9. Barr, F.G. and R.B. Womer, Rhabdomyosarcoma, in Oncology of Infancy and Childhood, S.H. Orkin, et al., Editors. 2009, Elsevier Inc. p. 743-782.

10. Smith, A.C., et al., New chromosome 11p15 epigenotypes identified in male monozygotic twins with Beckwith-Wiedemann syndrome. Cytogenet Genome Res, 2006. 113(1-4): p. 313-7.

11. Dagher, R. and L. Helman, Rhabdomyosarcoma: an overview. Oncologist, 1999. 4(1): p. 34-44.

12. Shapiro, D.N., et al., Fusion of PAX3 to a Member of the Forkhead Family of Transcription Factors in Human Alveolar Rhabdomyosarcoma. Cancer Research, 1993. 53: p. 5108-5112.

13. Linardic, C.M., PAX3-FOXO1 fusion gene in rhabdomyosarcoma. Cancer Lett, 2008. 270(1): p. 10-8.

14. Galili, N., et al., Fusion of a fork head domain gene to PAX3 in the solid tumor alveolar rhabdomyosarcoma. Nature Genetics, 1993. 5: p. 230-235.

15. Sorensen, P.H., et al., PAX3-FKHR and PAX7-FKHR gene fusions are prognostic indicators in alveolar rhabdomyosarcoma: a report from the children's oncology group. J Clin Oncol, 2002. 20(11): p. 2672-9.

16. Epstein, J.A., et al., Pax3 inhibits myogenic differentiation of cultures myoblast cells. The Journal of Biological Chemistry, 1995. 270(20): p. 11719-11722.

17. Bernasconi, M., et al., Induction of apoptosis in rhabdomyosarcoma cells through down-regulation of PAX proteins. Proc Natl Acad Sci U S A, 1996. 93: p. 1316413169. 
18. Anderson, J., et al., PAX3-FKHR Induces Morphological Change and Enhances Cellular Proliferation and Invasion in Rhabdomyosarcoma. The American Journal of Pathology, 2001. 159(3): p. 1089-1096.

19. Hawke, T.J. and D.J. Garry, Myogenic satellite cells: physiology to molecular biology. J Appl Physiol (1985), 2001. 91(2): p. 534-51.

20. Djaldetti, M., et al., Muscle cells produce a low molecular weight factor with anticancer activity. Clin Exp Metastasis, 1996. 14(3): p. 189-96.

21. Chenghua, L., et al., Experimental study on mechanism and rarity of metastases in skeletal muscle. Chinese Medical Journal, 2002. 115(11): p. 1645-1649.

22. Parlakian, A., et al., Skeletal muscle phenotypically converts and selectively inhibits metastatic cells in mice. PLoS One, 2010. 5(2): p. e9299.

23. Tiffin, N., et al., PAX7 expression in embryonal rhabdomyosarcoma suggests an origin in muscle satellite cells. Br J Cancer, 2003. 89(2): p. 327-32.

24. Anderson, J., et al., Genes, chromosomes, and rhabdomyosarcoma. Genes Chromosomes Cancer, 1999. 26(4): p. 275-85.

25. Drummond, C.J., et al., Hedgehog Pathway Drives Fusion-Negative Rhabdomyosarcoma Initiated From Non-myogenic Endothelial Progenitors. Cancer Cell, 2018. 33(1): p. 108-124 e5.

26. Charytonowicz, E., et al., Alveolar rhabdomyosarcoma: is the cell of origin a mesenchymal stem cell? Cancer Lett, 2009. 279(2): p. 126-36.

27. Hettmer, S. and A.J. Wagers, Muscling in: Uncovering the origins of rhabdomyosarcoma. Nat Med, 2010. 16(2): p. 171-3.

28. Abraham, J., et al., Lineage of origin in rhabdomyosarcoma informs pharmacological response. Genes Dev, 2014. 28(14): p. 1578-91.

29. Lemmon, M.A. and J. Schlessinger, Cell signaling by receptor tyrosine kinases. Cell, 2010. 141(7): p. 1117-34.

30. MacKenzie, M.A.F., et al., Activation of the receptor tyrosine kinase kit is required for the proliferation of melanoblasts in the mouse embryo. Developmental Biology, 1997. 192(1): p. 99-107.

31. Fong, G.H., et al., Role of the Flt-1 receptor tyrosine kinase in regulating the assembly of vascular endothelium. Nature, 1995. 376(6535): p. 66-70.

32. Anton, E.S., et al., Receptor tyrosine kinase ErbB4 modulates neuroblast migration and placement in the adult forebrain. Nat Neurosci, 2004. 7(12): p. 1319-28.

33. Puri, M.C., et al., The Receptor Tyrosine Kinase Tie Is Required for Integrity and Survival of Vascular Endothelial-Cells. Embo Journal, 1995. 14(23): p. 58845891.

34. Pollak, M., Insulin and insulin-like growth factor signalling in neoplasia. Nat Rev Cancer, 2008. 8(12): p. 915-28.

35. Frisen, J., J. Holmberg, and M. Barbacid, Ephrins and their Eph receptors: multitalented directors of embryonic development. EMBO J, 1999. 18(19): p. 5159-65.

36. Fantl, W.J., D.E. Johnson, and L.T. Williams, Signaling by Receptor Tyrosine Kinases. Annual Review of Biochemistry, 1993. 62: p. 453-481.

37. Hubbard, S.R. and J.H. Till, Protein tyrosine kinase structure and function. Annu Rev Biochem, 2000. 69: p. 373-98. 
38. Vieira, A.V., C. Lamaze, and S.L. Schmid, Control of EGF receptor signaling by clathrin-mediated endocytosis. Science, 1996. 274(5295): p. 2086-9.

39. Le Roy, C. and J.L. Wrana, Clathrin- and non-clathrin-mediated endocytic regulation of cell signalling. Nat Rev Mol Cell Biol, 2005. 6(2): p. 112-26.

40. Waterman, H. and Y. Yarden, Molecular mechanisms underlying endocytosis and sorting of ErbB receptor tyrosine kinases. FEBS Lett, 2001. 490(3): p. 142-52.

41. Wiley, H.S. and P.M. Burke, Regulation of receptor tyrosine kinase signaling by endocytic trafficking. Traffic, 2001. 2(1): p. 12-8.

42. Pandey, A., R.A. Lindberg, and V.M. Dixit, Receptor orphans find a family. Current Biology, 1995. 5(9): p. 986-989.

43. Pasquale, E.B., Eph receptors and ephrins in cancer: bidirectional signalling and beyond. Nat Rev Cancer, 2010. 10(3): p. 165-80.

44. Himanen, J.P., N. Saha, and D.B. Nikolov, Cell-cell signaling via Eph receptors and ephrins. Curr Opin Cell Biol, 2007. 19(5): p. 534-42.

45. Kullander, K. and R. Klein, Mechanisms and functions of Eph and ephrin signalling. Nat Rev Mol Cell Biol, 2002. 3(7): p. 475-86.

46. Kania, A. and R. Klein, Mechanisms of ephrin-Eph signalling in development, physiology and disease. Nat Rev Mol Cell Biol, 2016. 17(4): p. 240-56.

47. Gerety, S.S. and D.J. Anderson, Cardiovascular ephrinB2 function is essential for embryonic angiogenesis. Development, 2002. 129(6): p. 1397-1410.

48. Arvanitis, D. and A. Davy, Eph/ephrin signaling: networks. Genes Dev, 2008. 22(4): p. 416-29.

49. Nakayama, M., et al., Spatial regulation of VEGF receptor endocytosis in angiogenesis. Nat Cell Biol, 2013. 15(3): p. 249-60.

50. Pasquale, E.B., Eph-ephrin bidirectional signaling in physiology and disease. Cell, 2008. 133(1): p. 38-52.

51. Adams, R., et al., The cytoplasmic domain of the ligand ephrinB2 is required for vascular morphogenesis but not cranial neural crest migration. cell, 2001. 104: p. 57-69.

52. Salvucci, O., et al., EphrinB2 controls vessel pruning through STAT1-JNK3 signalling. Nat Commun, 2015. 6: p. 6576.

53. Klein, R., Eph/ephrin signalling during development. Development, 2012. 139(22): p. 4105-9.

54. Gucciardo, E., N. Sugiyama, and K. Lehti, Eph- and ephrin-dependent mechanisms in tumor and stem cell dynamics. Cell Mol Life Sci, 2014.

55. Barrios, A., et al., Eph/Ephrin Signaling Regulates the Mesenchymal-to-Epithelial Transition of the Paraxial Mesoderm during Somite Morphogenesis. Current Biology, 2003. 13(18): p. 1571-1582.

56. Watanabe, T., et al., EphrinB2 coordinates the formation of a morphological boundary and cell epithelialization during somite segmentation. Proc Natl Acad Sci U S A, 2009. 106(18): p. 7467-72.

57. Durbin, L., et al., Eph signaling is required for segmentation and differentiation of the somites. Genes and Development, 1999. 12: p. 3096-3109.

58. Dubrulle, J. and O. Pourquie, Coupling segmentation to axis formation. Development, 2004. 131(23): p. 5783-93. 
59. Krull, C.E., et al., Interactions of eph-related recetors and ligands confer rostrocaudal pattern to trunk neural crest cell migration. Current Biology, 1997. 7(8): p. 571-580.

60. Klein, R., Eph/ephrin signaling in morphogenesis, neural development and plasticity. Curr Opin Cell Biol, 2004. 16(5): p. 580-9.

61. Rasband, K., M. Hardy, and C.B. Chien, Generating X: formation of the optic chiasm. Neuron, 2003. 39(6): p. 885-8.

62. Williams, S.E., et al., Ephrin-B2 and EphB1 Mediate Retinal Axon Divergence at the Optic Chiasm. Neuron, 2003. 39(6): p. 919-935.

63. Stark, D.A., et al., Ephrin-A3 promotes and maintains slow muscle fiber identity during postnatal development and reinnervation. J Cell Biol, 2015. 211(5): p. 1077-91.

64. Genander, M., Eph and ephrins in epithelial stem cell niches and cancer. Cell Adh Migr, 2012. 6(2): p. 126-30.

65. Merlos-Suarez, A. and E. Batlle, Eph-ephrin signalling in adult tissues and cancer. Curr Opin Cell Biol, 2008. 20(2): p. 194-200.

66. Holmberg, J., et al., Ephrin-A2 reverse signaling negatively regulates neural progenitor proliferation and neurogenesis. Genes Dev, 2005. 19(4): p. 462-71.

67. Gschwind, A., O.M. Fischer, and A. Ullrich, The discovery of receptor tyrosine kinases: targets for cancer therapy. Nature Reviews Cancer, 2004. 4: p. 361.

68. Bache, K.G., T. Slagsvold, and H. Stenmark, Defective downregulation of receptor tyrosine kinases in cancer. EMBO J, 2004. 23(14): p. 2707-12.

69. Hojjat-Farsangi, M., Small-molecule inhibitors of the receptor tyrosine kinases: promising tools for targeted cancer therapies. Int J Mol Sci, 2014. 15(8): p. 13768-801.

70. Bhullar, K.S., et al., Kinase-targeted cancer therapies: progress, challenges and future directions. Mol Cancer, 2018. 17(1): p. 48.

71. Arora, A. and E.M. Scholar, Role of tyrosine kinase inhibitors in cancer therapy. J Pharmacol Exp Ther, 2005. 315(3): p. 971-9.

72. Surawska, H., P.C. Ma, and R. Salgia, The role of ephrins and Eph receptors in cancer. Cytokine Growth Factor Rev, 2004. 15(6): p. 419-33.

73. Chen, J., Regulation of tumor initiation and metastatic progression by Eph receptor tyrosine kinases. Adv Cancer Res, 2012. 114: p. 1-20.

74. Chong, L.D., et al., Fibroblast Growth Factor Receptor-Mediated Rescue of xEphrinB1 Induced Cell Dissociation in Xenopus Embryos. Molecular and Cellular Biology, 2000. 20(2): p. 724-734.

75. Brantley-Sieders, D.M., et al., The receptor tyrosine kinase EphA2 promotes mammary adenocarcinoma tumorigenesis and metastatic progression in mice by amplifying ErbB2 signaling. J Clin Invest, 2008. 118(1): p. 64-78.

76. Larsen, A.B., et al., Activation of the EGFR gene target EphA2 inhibits epidermal growth factor-induced cancer cell motility. Mol Cancer Res, 2007. 5(3): p. 28393.

77. Zelinski, D.P., et al., EphA2 overexpression causes tumorigenesis of mammary epithelial cells. Cancer Res, 2001. 61(5): p. 2301-6. 
78. Landen, C.N., Jr., et al., Efficacy and antivascular effects of EphA2 reduction with an agonistic antibody in ovarian cancer. J Natl Cancer Inst, 2006. 98(21): p. 1558-70.

79. Vihanto, M.M., et al., Hypoxia up-regulates expression of Eph receptors and ephrins in mouse skin. FASEB J, 2005. 19(12): p. 1689-91.

80. Noren, N.K., et al., Interplay between EphB4 on tumor cells and vascular ephrinB2 regulates tumor growth. Proceedings of the National Academy of Sciences of the United States of America, 2004. 101(15): p. 5583-5588.

81. Berardi, A.C., et al., Up-regulation of EphB and Ephrin-B Expression in Rhabdomyosarcoma. Anticancer Research, 2008. 28: p. 763-770.

82. Clifford, N., et al., The EphA3 receptor is expressed in a subset of rhabdomyosarcoma cell lines and suppresses cell adhesion and migration. J Cell Biochem, 2008. 105(5): p. 1250-9.

83. Aslam, M.I., et al., PDGFRbeta reverses EphB4 signaling in alveolar rhabdomyosarcoma. Proc Natl Acad Sci U S A, 2014.

84. Randolph, M.E., et al., EphB4/EphrinB2 therapeutics in Rhabdomyosarcoma. PLoS One, 2017. 12(8): p. e0183161. 


\title{
Chapter 2:
}

\section{Eph and ephrin Expression in Mouse and Canine Rhabdomyosarcoma}

\author{
Ronnie LaCombe ${ }^{1}$, Morgan Seibert ${ }^{1}$, and DDW Cornelison ${ }^{1,2}$
}

\footnotetext{
${ }^{1}$ Division of Biological Sciences and Bond Life Sciences Center, University of Missouri, Columbia, MO

2 to whom correspondence should be addressed
} 


\section{Abstract}

Rhabdomyosarcoma (RMS), the most common soft tissue tumor in children, develops to resemble immature skeletal muscle and has been proposed to derive from skeletal muscle stem cells. It is an aggressive cancer with a 5-year survival rate of $24 \%$ if it has metastasized. Current treatment options are restricted to surgery, chemotherapy and radiation, so there is a significant unmet need for targeted therapies. Eph receptor tyrosine kinases have been implicated in the development and progression of many other tumor types. Recent results from our group identified several Eph receptors expressed by primary muscle stem cells, which led us to screen for protein expression of Ephs and their ligands ephrins in canine RMS primary tumors as well as mouse RMS cell lines. Screens for mRNA and protein expression revealed that RMS cells express many but not all of the Ephs and ephrins. Expression patterns were mostly similar between canine and mouse tumors. Most Ephs and ephrins were membrane localized, but some were expressed in the perinuclear regions or the nucleus in some instances. Only one Eph or ephrin showed aberrant expression and localization to the nucleus in all of the canine and mouse RMS samples - EphA1 - indicating that it might play pivotal roles in RMS. 


\section{Introduction}

Rhabdomyosarcoma (RMS) is an aggressive childhood cancer that accounts for nearly half of all childhood soft tissue tumors [1]. There are about 350 new cases a year, and in cases where the cancer has already metastasized, the 5-year survival rates drop to below 24\% [2-4]. There are two main subtypes of RMS - embryonal (ERMS) and alveolar (ARMS). ERMS is the less aggressive subtype and accounts for $75 \%$ of RMS cases, and occurs most commonly in the head and neck region $[1,2]$. ARMS, the more aggressive subtype, is most commonly found in the extremities, but metastatic tumors can be found anywhere. Treatment for both types of RMS depends on how the cancer has progressed, but often involves surgery, chemotherapy, and radiation. Unfortunately, development of targeted therapies has not been successful, so identification of a druggable pathway is of high interest and importance.

Receptor tyrosine kinases (RTKs) are a family of proteins steadily gaining more attention as targets for drug development. Of the 58 RTKs in the human genome, 48 have been identified as oncogenes and 30 have been identified as necessary for oncogenesis [5]. The largest of the RTK families is the Eph receptors. There are 14 members divided into two classes - EphA receptors and EphB receptors [6]. They bind to their membranebound ephrin ligands, respectively: ephrinAs which tether to the membrane by a glycosylphosphatidlyinositol (GPI) anchor and ephrinBs which are transmembrane proteins [7]. Together, they are involved in cell-to-cell contact communication capable of signaling into the receptor-bearing (forward) and ligand-expressing (reverse) cells [8]. Eph and ephrin signaling is perhaps best known for its role in guiding axons, where they form boundaries and direction cues that help neurons find their appropriate targets [9]. 
The effects of Eph and ephrin signaling expand in the context of cancer. Eph and ephrin expression is deregulated in many cancers (reviewed in $[10,11])$. Their functions vary widely and are context-dependent, but involve promoting tumorigenesis, metastasis, proliferation, angiogenesis and cancer stem cell maintenance [12-15].

Ephs and ephrins also play a role in skeletal muscle development. In vitro, skeletal muscle stem cells (satellite cells) respond repulsively to and differentiate oriented in parallel to several different ephrins, most significantly to ephrinA5 and ephrinB1 [16]. In quail embryos, grafted satellite cells obey the same ephrin boundaries as neural crest cells migrating out of the neural tube and the ephrin boundaries directing muscle precursors to exit the dermomyotome and travel to the limb bud [16]. In addition, ephrinA3 is expressed specifically on slow muscle fibers while EphA8 is expressed at neuromuscular junctions on fast myofibers. The repulsive interactions of EphA8 and ephrinA3 are involved in proper innervation with fast or slow motor neurons, which plays a direct role in determining if a fiber will be a slow or fast myofiber [17].

Ephs and ephrins involvement in tumorigenesis and progression and also skeletal muscle development makes it likely that they play an integral role in one or more stages of RMS formation to metastasis. In this study, we investigated which Ephs and ephrins may be involved in RMS by utilizing a cross-species approach. A screen for Eph and ephrin expression was performed by immunofluorescence on canine RMS tumor sections and mouse RMS cell lines. Many of the Ephs and ephrins are expressed to varying degrees, but only one was atypically expressed in all canine tumor sections and mouse cell lines, EphA1. This indicates that EphA1 may perform a common function in RMS across species. 


\section{$\underline{\text { Results }}$}

\section{Primary canine RMS tumors express some Eph and ephrins}

In order to determine which Eph and ephrins are expressed by primary canine RMS tumors, we used commercially available antibodies on sections from two primary tumors from two separate dogs: a nasal tumor and a limb tumor. The nasal tumor was probed for EphA1, EphA3, EphA7, EphB4, ephrinA1, and ephrinB2 protein. Expression of EphA1, EphA3, and ephrinA1 was detected at varying levels (Figure 2-1A). In the limb tumor we detected EphA1, EphA2, EphB1, ephrinA2 and ephrinB1 at high levels; EphA3, EphA4, EphB4, EphB6, ephrinA1, ephrinA3, ephrinA4, and ephrinA5 at low levels; and no expression of EphA7, EphA8, EphB2, and ephrinB2 (Figure 2-1B). Expression also varied between cells within the same section. While all cells were positive for EphA1, the intensity varied between cells. In other cases, only some of the cells were positive, such as for EphA2 and ephrinA1. Variation in expression of Ephs and ephrins between cells is not unexpected as the tumor sections are a heterogenous population of cells. Expression varied not only in frequency and intensity, but also in subcellular location. While most of the detected Ephs and ephrins displayed expression patterns consistent with transmembrane proteins, EphA1 and EphA4 were co-localized with DAPI. This suggests that they may be in the nucleus rather than at the plasma membrane.

\section{Eph and ephrin expression in mouse RMS cell lines}

In order to test which Ephs and ephrins could play conserved roles in RMS, we compared expression in canine RMS to mouse RMS. Mouse RMS cell lines were derived 
from primary or metastatic tumors in transgenic mice designed to develop ERMS or ARMS. Cell lines U23674 and U48484 represent the ARMS subtype as they are derived from mice with forced expression of the Pax3-FOXO1 fusion protein [18]. Cell lines U33915 and U57810 represent the ERMS subtype, which does not express the fusion protein but instead is driven by mutations to $P T C H 1$ and $p 53$ in a muscle-specific fashion [19].

First, we wanted to see which Eph and ephrin mRNAs were expressed by mouse RMS cells and how this expression compared to mouse myoblasts. We performed reverse-transcription PCR on cDNA from all four mouse RMS cells lines as well as the immortalized mouse myoblast cell line C2C12. In most cases, an Eph or ephrin was expressed by all RMS cell lines and C2C12s or none of them (Figure 2-2). No expression of ephrinA2, ephrinB3, EphA8, or EphB1 was detected in any of the cell lines. Expression of ephrinA1, ephrinA4, ephrinA5, ephrinB1, ephrinB2, EphA1, EphA2, EphA3, EphA4, EphA7, EphB2, EphB3, and EphB4 was detected in all cell lines, but sometimes at varying levels. Ephs or ephrins which had variable expression often correlated with differences in subtype of RMS. EphrinA3, EphA6, EphB2, EphB3, and EphB6 were expressed in the ERMS cell lines (U33915 and U57810) but either absent or lower levels in the ARMS cell lines (U23674 and U48484), while EphA4 was expressed at higher levels in ARMS cell lines than ERMS cell (Figure 2-2).

After screening for mRNA expression, we moved to screening for protein expression of Ephs and ephrins in mouse RMS cells by immunocytochemistry. Mouse RMS cell lines expressed all of the Ephs and ephrins that were tested (Figure 2-3). The robustness and localization of protein expression varied both between Ephs and ephrins 
as well as between the cell lines. Many of the Ephs and ephrins exhibited localization patterns consistent with a transmembrane protein, with a clear example of EphA2 (Figure 2-3). We also detected a few of the Ephs and ephrins in atypical locations. EphA8 and ephrinA2 were detected in perinuclear regions (Figure 2-3). Several of the Ephs and ephrins were unexpectedly detected in the nucleus. Nuclear localization varied between cell lines for some of the Ephs and ephrins - EphA5 was detected in the nucleus of U23674 and U57810 cell lines but less strongly in the nucleus of U33915 and U48484 cell lines (Figure 2-3). Of the Ephs and ephrins exhibiting nuclear localization, EphA1 was the only one that appeared to be exclusively expressed in the nucleus of all four cell lines (Figure 2-3).

Eph and ephrin mRNA and protein expression were not always concordant. We were able to detect protein expression of ephrinA2, ephrinA3, EphA8, and EphB1 even though we did not detect any mRNA expression. This is unlikely to be caused by a genetic mutation in RMS altering primer binding sites as these mRNAs were also undetected in $\mathrm{C} 2 \mathrm{C} 12 \mathrm{~s}$. It is more likely that the mRNA is rapidly degraded while the protein is stable. A summary of Eph and ephrin mRNA and protein expression in mouse cell lines can be found in Table 2-1.

We also compared Eph and ephrin protein expression in the canine tumor and mouse RMS lines to primary mouse satellite cells, a proposed cell of origin for RMS [16]. A few differences between canine and mouse RMS are readily apparent in this comparison. Only a subset of cells from canine tumors expressed ephrinA1 but nearly all mouse satellite cells and RMS cells did (Figure 3-1 and 3-2). While all mouse RMS cells lines expressed EphA5, EphA7, and EphA8, they were not expressed in mouse satellite 
cells or canine tumors. The most intriguing difference was with EphA1 expression: all canine and mouse RMS cells expressed EphA1, while only a subset of satellite cells expressed it. Conservation of a difference in EphA1 expression across species suggests that EphA1 might play an important role in RMS formation or progression, and further studies are needed to elucidate this role.

\section{$\underline{\text { Discussion }}$}

Given the prevalence of RTKs in cancer, their increasing prevalence as targets in drug development, and their involvement in skeletal muscle development, we examined the expression of Eph receptors as tumor-promoting factors in RMS and as a possible target for future drug development. Eph receptors are the largest family of RTKs in humans and are involved in development of healthy tissues as well as development and progression of many types of cancer $[6,20]$. Despite their well-established role in cancer biology, very little is known about their role in rhabdomyosarcoma.

This study is unique in that it took a multi-species approach to exploring Eph and ephrin expression in RMS. Similarities in expression and localization between RMS of different species and different from normal tissue would suggest an increased likelihood of identifying a common (and therefore potentially important) factor in RMS formation or progression. Additionally, the use of primary tumor sections in situ provided a means of confirming that any expression patterns detected were not an artifact of cell culture. Of the Ephs and ephrins that were screened, which were limited due to the number of available sections, expression between nasal and limb tumors was similar except for EphA3 and EphB4. Mouse RMS cell lines expressed all of the Ephs and ephrins that were screened. Differences arose in localization and expression levels. The only Eph or 
ephrin that was expressed in a consistent manner across the canine tumor sections and mouse RMS sections that was also different from expression in satellite cells was EphA1. While only $50 \%$ of satellite cells express EphA1, all of the RMS cells expressed it but in an atypical location. This conserved difference in three different species from healthy cells will be the focus of further studies. 


\section{Materials and Methods}

\section{Cell culture and samples}

Canine tumor samples were graciously donated by Dr. Jeffrey Bryan at the University of Missouri School of Veterinary Medicine. They came from a nasal or limb tumor from two different dogs. Tumors were formalin-fixed and paraffin embedded before sectioning. Mouse rhabdomyosarcoma cell lines were graciously provided by Dr. Charles

Keller. These cell lines were generated from tumors in transgenic mice with the following mutations to cause RMS: U23674 (Myf6Cre/Pax3-Foxo1/p53-/-), U33915 (Pax7CreER, Ptch1, p53 ${ }^{-/-}$), U48484 (Myf6Cre/Pax3-Foxo1/p53 ${ }^{-/}$), U57810 (Myf6Cre/p53 ${ }^{-/}$). Mouse RMS cell lines were cultured in DMEM with 10\% Fetal Bovine Serum and 1\% penicillin/streptomycin (Sigma) at $37{ }^{\circ} \mathrm{C}$ and $5 \% \mathrm{CO}_{2}$ in a humidified incubator.

\section{Reverse transcriptase polymerase chain reaction}

Intron spanning primer sequences and product lengths were previously described.[16] Total RNA was harvested from proliferating mouse RMS cell lines and C2C12 myoblasts, then reverse transcribed to cDNA (SuperScript III, Invitrogen). $50 \mathrm{ng}$ of each sample was used as template for polymerase chain reactions.

\section{Immunofluorescence}

For fluorescent immunocytochemistry of cultured RMS cells, mouse cell lines were plated onto glass coverslips coated with $6.6 \%$ gelatin and allowed to adhere at least overnight. Cells were blocked in $10 \%$ normal goat serum with $1 \%$ Nonidet-P40 for 1 hour at room temperature for all primaries except for those raised in goat, in which case cells were blocked with $20 \%$ BlokHen (Aves Labs) for 1 hour at room temperature. Cells were then incubated with primary antibody overnight at $4^{\circ} \mathrm{C}$, washed, incubated with 
secondary antibody for 1 hour at room temperature, and washed again. Cells were then stained with Alexa 488-labeled phalloidin (Invitrogen) diluted 1:20 from a stock solution of $6.6 \mu \mathrm{M}$ into PBS and incubated at room temperature for 30 minutes. Cells were then washed and mounted in Vectashield containing DAPI (Vector Labs).

Canine tumor sections were first deparaffinized in xylene-substitute Histo-Clear (National Diagnostics) using three changes for 5 minutes each. Sections were then rehydrated by washing twice in $100 \%$ ethanol for 10 minutes each then $95 \%$ ethanol for 10 minutes followed by a 1-minute wash in deionized water with stirring. Excess liquid was aspirated and then were processed for antigen retrieval. First, cells were rinsed 3 times in PBS for 5 minutes. Then cells were rinsed in $10 \mathrm{mM}$ citrate buffer for 5 minutes. Citrate buffer was replaced, and the sections were placed in the Antigen Retriever (Aptum Biologics) for retrieval. After the retrieval cycle finished and sections had cooled, they were rinsed 3 times with deionized water then PBS for 15 minutes. After this, sections were blocked and stained as described for coverslips above.

Primary antibodies (Santa Cruz unless otherwise noted) and dilutions were: EPHA1 1:200, N-terminal EPHA1 1:100, EPHA2 1:200, EPHA3 1:200, EPHA4 1:200, EPHA7 1:300, EPHA8 1:200, EPHB1 1:200, EPHB2 1:200, EPHB4 1:200, EPHB6 1:200 (AbCam), ephrin-A1 1:200, ephrin-A2 1:200, ephrin-A3 1:200, ephrin-A4 1:200, ephrin-A5 1:200 (AbCam), ephrin-B1 1:200, ephrin-B3 1:300. Secondary antibodies were raised in goat and conjugated with Alexa fluorophores and used at 1:500 (Invitrogen). All images were acquired and processed on an Olympus BX61 upright microscope using Slidebook software (Intelligent Imagine Innovations) or $\mu$ Manager software (www.micro-manager.org). Digital background subtraction was performed to 
remove to remove signal that was less than or equal to levels present in control samples (processed without primary antibody) and was applied equally to the entire field. 
A
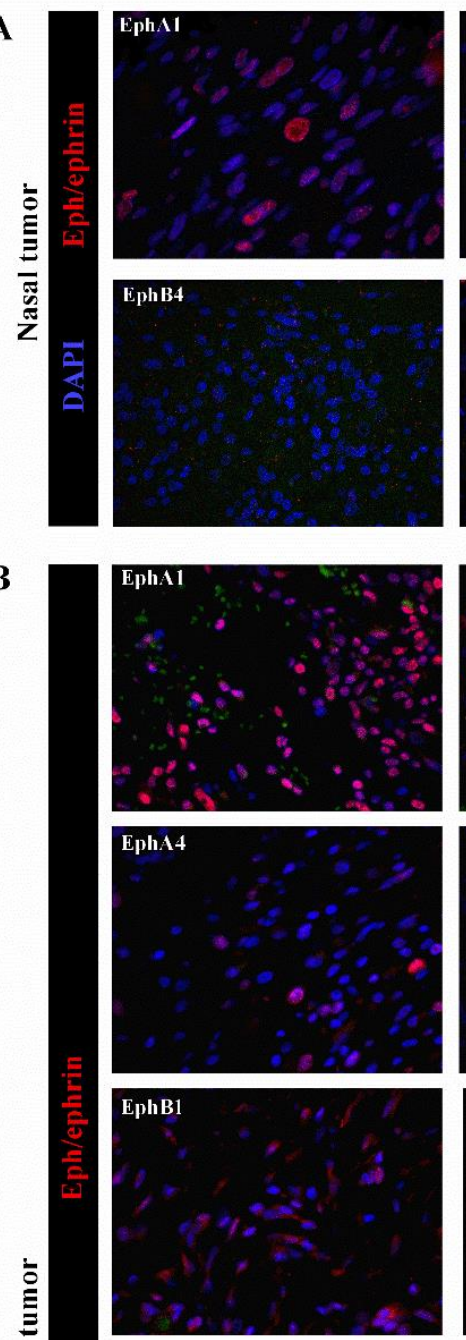

音
Eph A3

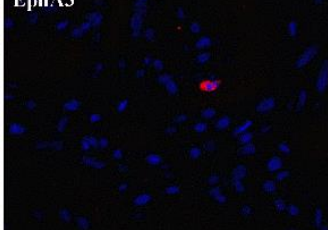

ephrin AI
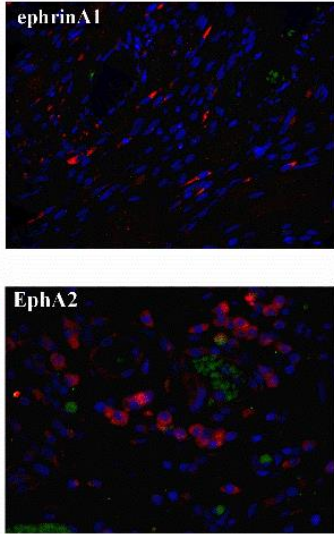

EphA7
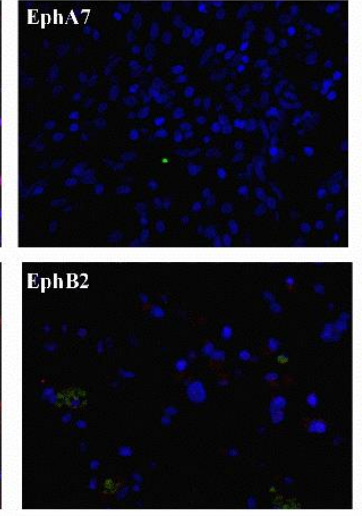

ephrinAI

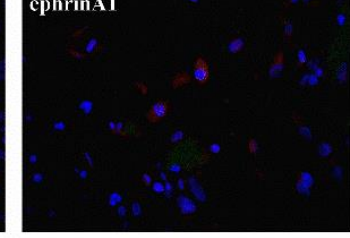

ephrinA3

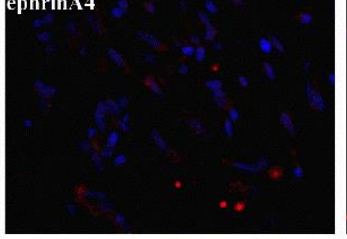

ephrinBI

ephrinB2

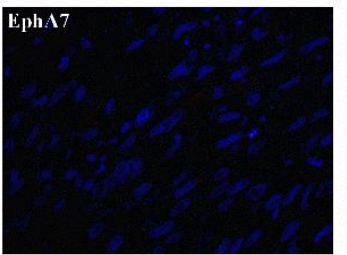

ephrin B2

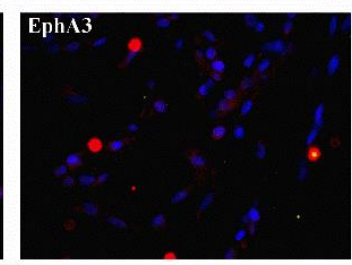

EphA8

8

옹

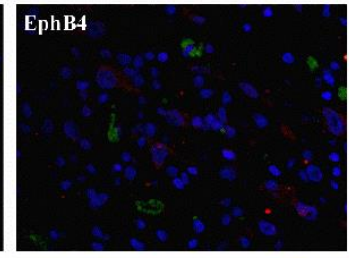

ephrinA2

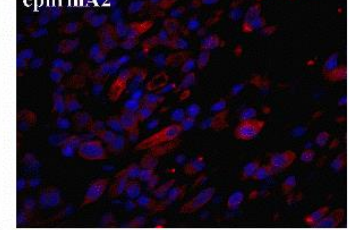

ephrinA5

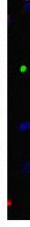


Figure 2-1. Eph and ephrin protein expression in primary canine RMS tumors Eph and- ephrin protein expression was investigated by immunofluorescence in a nasal primary tumor (A) and a limb primary tumor (B) from two different dogs that were formalin fixed and paraffin embedded. After deparaffinization, sections were stained for Ephs and ephrins (Alexa 555, red) and nuclei (DAPI, blue). The green in figure B is autofluorescence of red blood cells. Expression of Ephs and ephrins was variable in both intensity and the number of cells that were positive, from strong expression in all cells to no detectable expression. Of tested Ephs and ephrins, expression was comparable between the two tumors. 


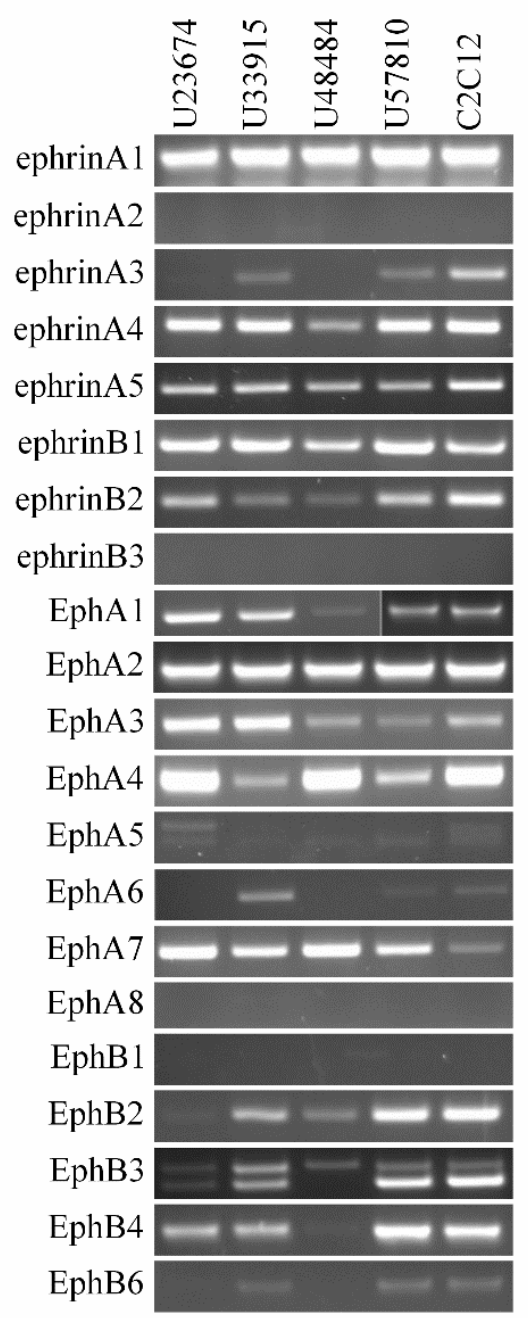

Figure 2-2. Eph and ephrin mRNA expression in mouse RMS cell lines

Eph and ephrin mRNA expression was investigated by RT-PCR in four mouse RMS cell lines, U23674 (ARMS), U33915 (ERMS), U48484 (ARMS), and U57810 (ERMS) as well as the mouse myoblast cell line $\mathrm{C} 2 \mathrm{C} 12$. RNA was collected from all cell lines and reverse-transcribed into cDNA. This cDNA was then used for PCR with intron-spanning primers to identify which mRNAs were expressed. 


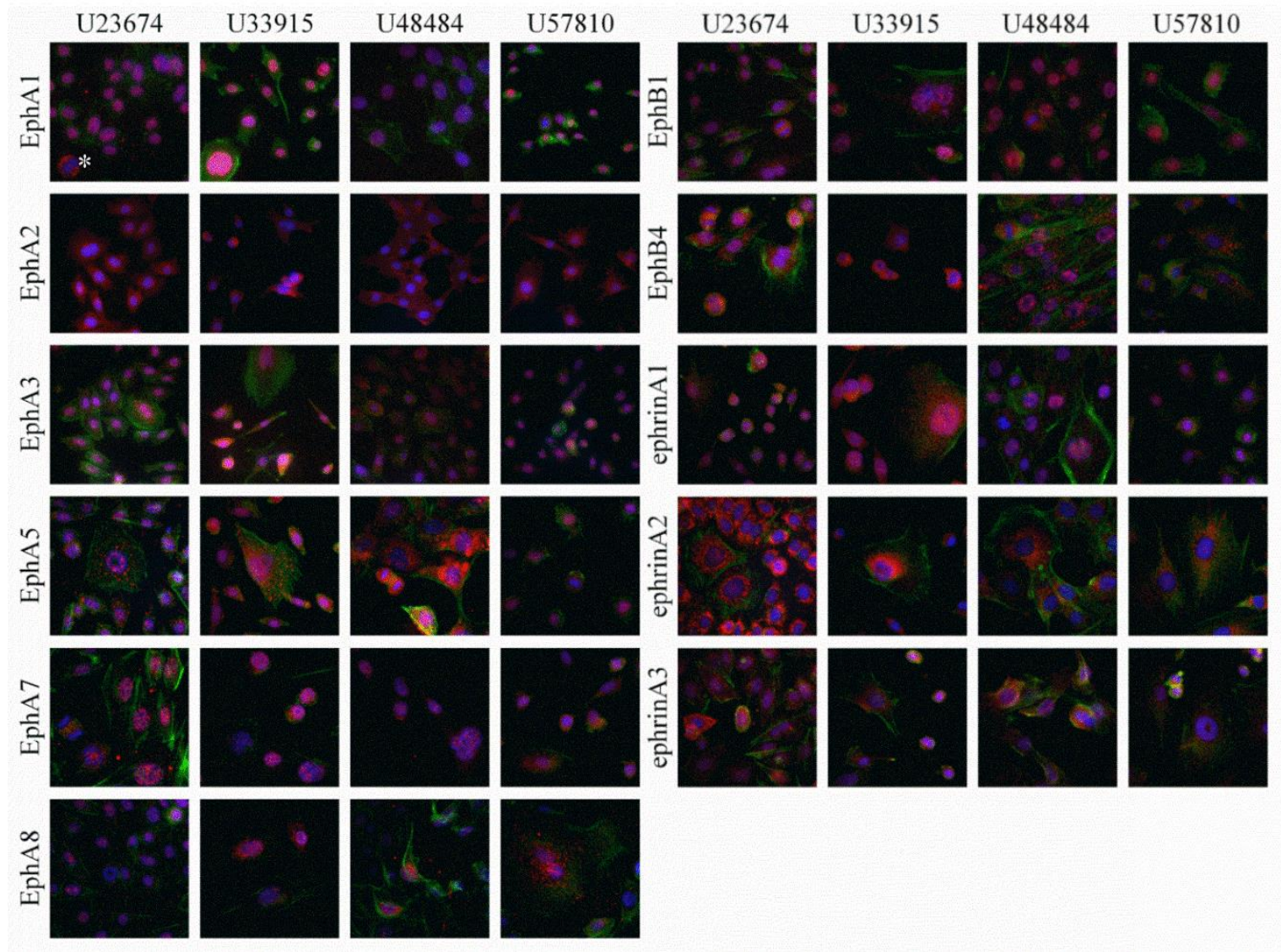

Figure 2-3. Eph and ephrin protein expression in mouse RMS cell lines

Eph and ephrin protein expression was investigated by immunofluorescence in four mouse RMS cell lines: U23674 (ARMS), U33915 (ERMS), U48484 (ARMS), U57810

(ERMS). Cells were grown on glass coverslips coated in gelatin, fixed with $4 \%$ PFA, and stained for Ephs and ephrins (Alexa 555, red), F-actin (phalloidin Alexa 488, green), and nuclei (DAPI, blue). Mouse RMS cell lines expressed all Ephs and ephrins tested, though expression intensity and localization vary both between Eph/ephrins and between cell lines. All Ephs and ephrins were localized to the cytoplasm or membrane except for EphA1, which was contained to the nucleus except in dividing cells, marked by an asterisk. 
Table 2-1. Eph and ephrin mRNA and protein expression in mouse RMS and myoblast $\mathrm{C2C12}$ cell lines.

\begin{tabular}{|c|c|c|c|c|c|c|c|c|c|c|}
\hline & & \multicolumn{2}{|c|}{$\mathrm{U} 23674$} & \multicolumn{2}{|c|}{ U33915 } & \multicolumn{2}{|c|}{ U48484 } & \multicolumn{2}{|c|}{ U57810 } & \multirow{2}{*}{$\begin{array}{l}\text { C2C12 } \\
\text { PCR }\end{array}$} \\
\hline & $\begin{array}{c}\text { Target } \\
\text { Size }\end{array}$ & PCR & Stain & PCR & Stain & PCR & Stain & PCR & Stain & \\
\hline ephrinA1 & 407 & 400 & $\begin{array}{l}\text { Nucleus, } \\
\text { Cytoplasm }\end{array}$ & 400 & $\begin{array}{l}\text { Nucleus, } \\
\text { Cytoplasm }\end{array}$ & 400 & $\begin{array}{l}\text { Nucleus, } \\
\text { Cytoplasm }\end{array}$ & 400 & Cytoplasm & 400 \\
\hline ephrinA2 & 407 & - & Cytoplasm & - & Cytoplasm & - & Cytoplasm & - & Cytoplasm & - \\
\hline ephrinA3 & 279 & - & Cytoplasm & - & $\begin{array}{l}\text { Cytoplasm, } \\
\text { perinuclear }\end{array}$ & - & Cytoplasm & - & Cytoplasm & $\begin{array}{l}600 \\
250\end{array}$ \\
\hline ephrinA4 & 352 & 350 & & 350 & & 350 & & 350 & & 350 \\
\hline ephrinA5 & 446 & 450 & & 450 & & 450 & & 450 & & 450 \\
\hline ephrinB1 & 296 & 300 & & 300 & & 300 & & 300 & & 300 \\
\hline ephrinB2 & 263 & 250 & & 250 & & 250 & & 250 & & 250 \\
\hline ephrinB3 & 354 & - & & - & & - & & - & & - \\
\hline EphA1 & 448 & 450 & Nuclear & 450 & Nuclear & 450 & Nuclear & 450 & Nuclear & 450 \\
\hline EphA2 & 321 & 300 & Cytoplasm & 300 & Cytoplasm & 300 & Cytoplasm & & Cytoplasm & 300 \\
\hline EphA3 & 384 & 400 & $\begin{array}{l}\text { Nucleus, } \\
\text { Cytoplasm }\end{array}$ & 400 & $\begin{array}{l}\text { Nucleus, } \\
\text { Cytoplasm }\end{array}$ & 400 & $\begin{array}{l}\text { Nucleus, } \\
\text { Cytoplasm }\end{array}$ & 400 & $\begin{array}{l}\text { Nucleus, } \\
\text { Cytoplasm }\end{array}$ & 400 \\
\hline EphA4 & 348 & 350 & & 350 & & 350 & & 350 & & 350 \\
\hline EphA5 & 397 & 400 & $\begin{array}{l}\text { Nucleus, } \\
\text { Cytoplasm }\end{array}$ & 400 & $\begin{array}{l}\text { Nucleus, } \\
\text { Cytoplasm }\end{array}$ & 400 & Cytoplasm & 400 & $\begin{array}{l}\text { Nucleus, } \\
\text { Cytoplasm }\end{array}$ & 400 \\
\hline EphA6 & 393 & - & & 400 & & - & & 400 & & 400 \\
\hline EphA7 & 290 & & $\begin{array}{l}\text { Nucleus, } \\
\text { Cytoplasm }\end{array}$ & & $\begin{array}{l}\text { Nucleus, } \\
\text { Cytoplasm }\end{array}$ & & $\begin{array}{l}\text { Nucleus, } \\
\text { Cytoplasm }\end{array}$ & & Cytoplasm & \\
\hline EphA8 & 400 & - & $\begin{array}{l}\text { Nucleus, } \\
\text { Cytoplasm }\end{array}$ & - & $\begin{array}{l}\text { Nucleus, } \\
\text { Cytoplasm }\end{array}$ & - & $\begin{array}{l}\text { Nucleus, } \\
\text { Cytoplasm }\end{array}$ & - & $\begin{array}{l}\text { Nucleus, } \\
\text { Cytoplasm }\end{array}$ & - \\
\hline EphB1 & 467 & - & $\begin{array}{l}\text { Nucleus, } \\
\text { Cytoplasm }\end{array}$ & - & $\begin{array}{l}\text { Nucleus, } \\
\text { Cytoplasm }\end{array}$ & - & $\begin{array}{l}\text { Nucleus, } \\
\text { Cytoplasm }\end{array}$ & - & $\begin{array}{l}\text { Nucleus, } \\
\text { Cytoplasm }\end{array}$ & - \\
\hline EphB2 & 359 & 350 & & 350 & & 350 & & 350 & & 350 \\
\hline EphB3 & 380 & 400 & & 400 & & 500 & & 400 & & 400 \\
\hline EphB4 & 392 & 400 & Cytoplasm & 400 & Cytoplasm & 400 & $\begin{array}{l}\text { Nucleus, } \\
\text { Cytoplasm }\end{array}$ & 400 & Cytoplasm & 400 \\
\hline EphB6 & 347 & - & & 350 & & - & & 350 & & 350 \\
\hline
\end{tabular}


Table 2-2. Eph and ephrin protein expression in mouse primary satellite cells,

canine tumor sections, and mouse RMS cell lines. Satellite cell data was collected by

FACS [16]. Color coding indicates how many cells were positive. Green, $80 \%$ or more.

Yellow, 20\%-80\%. Red, less than 20\%.

\begin{tabular}{|l|r|l|l|l|l|l|l|}
\hline & $\begin{array}{l}\text { Satellite } \\
\text { cells }\end{array}$ & $\begin{array}{l}\text { nasal } \\
\text { RMS }\end{array}$ & limb RMS & U23674 & U33915 & U48484 & U57810 \\
\hline ephrinA1 & 88 & $\begin{array}{l}\text { some } \\
\text { positive }\end{array}$ & $\begin{array}{l}\text { some } \\
\text { positive }\end{array}$ & Positive & Positive & Positive & Positive \\
\hline ephrinA2 & 91 & & Positive & Positive & Positive & Positive & Positive \\
\hline ephrinA3 & 97 & & Positive & Positive & Positive & Positive & Positive \\
\hline ephrinA4 & 6.4 & & $\begin{array}{l}\text { some } \\
\text { positive }\end{array}$ & & & & \\
\hline ephrinA5 & 62.4 & & $\begin{array}{l}\text { some } \\
\text { positive }\end{array}$ & & & & \\
\hline ephrinB1 & 98.5 & & Positive & & & & \\
\hline ephrinB2 & 1.4 & negative & negative & & & & \\
\hline ephrinB3 & 12.6 & & & & & & \\
\hline EphA1 & 46.1 & Positive & Positive & Positive & Positive & Positive & Positive \\
\hline EphA2 & 97.8 & & $\begin{array}{l}\text { some } \\
\text { positive }\end{array}$ & Positive & Positive & Positive & Positive \\
\hline EphA3 & 49.5 & $\begin{array}{l}\text { pew } \\
\text { positive }\end{array}$ & $\begin{array}{l}\text { some } \\
\text { positive }\end{array}$ & Positive & Positive & Positive & Positive \\
\hline EphA4 & 2.4 & & $\begin{array}{l}\text { some } \\
\text { positive }\end{array}$ & & & & \\
\hline EphA5 & 1 & & & Positive & Positive & Positive & Positive \\
\hline EphA6 & 5.4 & & & & & & \\
\hline EphA7 & 2.3 & negative & negative & Positive & Positive & Positive & Positive \\
\hline EphA & 4.9 & & negative & Positive & Positive & Positive & Positive \\
\hline EphB1 & 97.4 & & Positive & Positive & Positive & Positive & Positive \\
\hline EphB2 & 89.7 & & negative & & & & \\
\hline EphB3 & 10.17 & & & & & & \\
\hline EphB4 & 74 & negative & $\begin{array}{l}\text { some } \\
\text { positive }\end{array}$ & Positive & Positive & Positive & Positive \\
\hline EphB6 & 45.5 & & $\begin{array}{l}\text { some } \\
\text { positive }\end{array}$ & & & & \\
\hline
\end{tabular}




\section{$\underline{\text { Literature Cited }}$}

1. Gurney, J.G., et al., Soft Tissue Sarcomas, in Cancer Incidence and Survival among Children and Adolescents: United States SEER Program 1975-1995, L. Ries, et al., Editors. 1999, NIH Pub: Bethesda, MD. p. 111-123.

2. Ognjanovic, S., et al., Trends in childhood rhabdomyosarcoma incidence and survival in the United States, 1975-2005. Cancer, 2009. 115(18): p. 4218-26.

3. Perez, E.A., et al., Rhabdomyosarcoma in children: a SEER population based study. J Surg Res, 2011. 170(2): p. e243-51.

4. Davicioni, E., et al., Gene expression profiling for survival prediction in pediatric rhabdomyosarcomas: a report from the children's oncology group. J Clin Oncol, 2010. 28(7): p. 1240-6.

5. Hojjat-Farsangi, M., Small-molecule inhibitors of the receptor tyrosine kinases: promising tools for targeted cancer therapies. Int J Mol Sci, 2014. 15(8): p. 13768-801.

6. Pasquale, E.B., Eph-ephrin bidirectional signaling in physiology and disease. Cell, 2008. 133(1): p. 38-52.

7. Kullander, K. and R. Klein, Mechanisms and functions of Eph and ephrin signalling. Nat Rev Mol Cell Biol, 2002. 3(7): p. 475-86.

8. Gucciardo, E., N. Sugiyama, and K. Lehti, Eph- and ephrin-dependent mechanisms in tumor and stem cell dynamics. Cell Mol Life Sci, 2014.

9. Nakamoto, M., et al., Topographically specific effects of ELF-1 on retinal axon guidance in vitro and retinal axon mapping in vivo. Cell, 1996. 86(5): p. 755-66.

10. Pasquale, E.B., Eph receptors and ephrins in cancer: bidirectional signalling and beyond. Nat Rev Cancer, 2010. 10(3): p. 165-80.

11. Surawska, H., P.C. Ma, and R. Salgia, The role of ephrins and Eph receptors in cancer. Cytokine Growth Factor Rev, 2004. 15(6): p. 419-33.

12. Brantley-Sieders, D.M., et al., Ephrin-Al facilitates mammary tumor metastasis through an angiogenesis-dependent mechanism mediated by EphA receptor and vascular endothelial growth factor in mice. Cancer Res, 2006. 66(21): p. 1031524.

13. Brantley-Sieders, D.M., et al., The receptor tyrosine kinase EphA2 promotes mammary adenocarcinoma tumorigenesis and metastatic progression in mice by amplifying ErbB2 signaling. J Clin Invest, 2008. 118(1): p. 64-78.

14. Lv, J., et al., EphB4 promotes the proliferation, invasion, and angiogenesis of human colorectal cancer. Exp Mol Pathol, 2016. 100(3): p. 402-8.

15. Chen, J., W. Song, and K. Amato, Eph receptor tyrosine kinases in cancer stem cells. Cytokine \& Growth Factor Reviews, 2014.

16. Stark, D.A., et al., Eph/ephrin interactions modulate muscle satellite cell motility and patterning. Development, 2011. 138(24): p. 5279-89.

17. Stark, D.A., et al., Ephrin-A3 promotes and maintains slow muscle fiber identity during postnatal development and reinnervation. J Cell Biol, 2015. 211(5): p. 1077-91.

18. Keller, C. and M.R. Capecchi, New genetic tactics to model alveolar rhabdomyosarcoma in the mouse. Cancer Res, 2005. 65(17): p. 7530-2. 
19. Rubin, B.P., et al., Evidence for an unanticipated relationship between undifferentiated pleomorphic sarcoma and embryonal rhabdomyosarcoma.

Cancer Cell, 2011. 19(2): p. 177-91.

20. Dodelet, V.C. and E.B. Pasquale, Eph receptors and ephrin ligands: embryogenesis to tumorigenesis. Oncogene, 2000. 29(49): p. 5614-5619.

21. Aslam, M.I., et al., PDGFRbeta reverses EphB4 signaling in alveolar rhabdomyosarcoma. Proc Natl Acad Sci U S A, 2014.

22. Randolph, M.E., et al., EphB4/EphrinB2 therapeutics in Rhabdomyosarcoma. PLoS One, 2017. 12(8): p. e0183161.

23. Clifford, N., et al., The EphA3 receptor is expressed in a subset of rhabdomyosarcoma cell lines and suppresses cell adhesion and migration. J Cell Biochem, 2008. 105(5): p. 1250-9. 


\title{
Chapter 3:
}

\section{Atypical localization of EphA1 in Rhabdomyosarcoma}

\author{
Ronnie LaCombe ${ }^{1}$, Morgan Seibert ${ }^{1}$, and DDW Cornelison ${ }^{1,2}$
}

\footnotetext{
${ }^{1}$ Division of Biological Sciences and Bond Life Sciences Center, University of Missouri, Columbia, MO

2 to whom correspondence should be addressed
} 


\section{Abstract}

While the canonical role of receptor tyrosine kinases (RTKs) is to receive and transmit signals at the cell surface, it is not their only mode of action. In particular, aberrant nuclear localization of RTKs has been shown to promote cancer progression, with the classic case being ErbBs in breast cancer. Rhabdomyosarcoma (RMS), the most common soft tissue tumor in children, develops to resemble immature skeletal muscle and has been proposed to derive from muscle stem/progenitor cells (satellite cells). It is an aggressive cancer with a 5-year survival rate of $33 \%$ if it has metastasized. Current treatment options are limited to surgery, chemotherapy and radiation therapy, thus there is a significant unmet need for targeted therapies. Eph receptor tyrosine kinases have been implicated in the development and progression of many other tumor types, but there are only two recently published studies describing Ephs localization to the nucleus and to date no other nuclear RTKs have been identified in RMS. Recent results from our group identified multiple Eph receptors expressed by primary satellite cells as well as by RMS from canine tumors and mouse RMS cell lines. We noted strong expression of EphA1 in the nucleus of interphase cells of both canine and mouse RMS. In this study, we describe nuclear expression of EphA1 was also detected in human RMS cell lines as well. This localization pattern changes in dividing cells, with EphA1 localizing to distinct subcellular compartments in distinct phases of the cell cycle. EphA1 in the nucleus of RMS cells appears to exist as a full-length polypeptide that might be phosphorylated. These data represent the case of a nuclear RTK in RMS, and the first time that EphA1 has been detected in the nucleus of any cell type. 


\section{$\underline{\text { Introduction }}$}

Rhabdomyosarcoma (RMS) is an aggressive childhood cancer that accounts for nearly half of all childhood soft tissue tumors [1]. In cases where the cancer has already metastasized, the 5-year survival rate drops to $24 \%$ [2-4]. There are two main subtypes of RMS - embryonal (ERMS) and alveolar (ARMS). ERMS is the less aggressive subtype accounting for $75 \%$ of RMS cases, and occurs most commonly in the head and neck region $[1,2]$. ARMS, the more aggressive subtype, is most commonly found in the extremities, but metastatic tumors can be found anywhere. Treatment for both types of RMS depends on how the cancer has progressed but is limited to surgery, chemotherapy, and radiation therapy. Not all RMS tumors are resectable, particularly those which have metastasized, and chemotherapy and radiation therapy have severe side effects particularly in pediatric cancers. Because targeted therapies for RMS are not yet available, identification of druggable targets is of high interest and importance.

Receptor tyrosine kinases (RTKs) are transmembrane proteins responsible for responding to external stimuli by initiating internal signaling cascades and thus transmitting information into a cell. Following activation, RTKs are often endocytosed and trafficked to lysosomes for degradation or recycled and sent back to the cell surface [5]. However, recent evidence points to other possible modalities such as signaling from organelles such as the mitochondria and nucleus [6-9]. Of the 58 RTKs identified so far, 19 have been detected in the nucleus [10]. This nuclear localization of RTKs is commonly found in cancer, and with a few exceptions is associated with a less favorable prognosis [8]. 
The current state of the field with regard to expression and function of nuclear RTKs in different cell types is summarized in Table 3-1. When comparing activities of nuclear RTKs across families, it becomes apparent that a majority of them are acting as transcriptional regulators (Table 3-1). Of the RTKs in the nucleus, the ErbB family is the best characterized. ErbB1, ErbB2, and ErbB3 have each been detected in the nucleus of breast cancer, lung cancer, and/or prostate cancer as full-length receptors and are associated with increased proliferation and decreased sensitivity to growth-inhibitory signals $[9,11,12]$. Nuclear ErbB4, on the other hand, is associated with growth suppression and improved prognosis [13]. Interestingly, it exists in the nucleus as a fragment instead of a full-length protein and its activity promotes growth inhibition and/or apoptosis $[7,9,13]$. Thus, the ErbB family provides examples of nuclear RTKs with both tumor promoting and tumor suppressing activities. Potential explanations for the opposing effects of ErbB1-3 and ErbB4 are that they are different family members, they are differentially cleaved or otherwise modified, and they have different mechanisms of membrane-to-nucleus trafficking [14].

While the Eph family of RTKs has not been studied to the extent that the ErbB family has, three Eph receptors have recently been detected in the nucleus of cancer cell lines. EphA4 localized to the nucleus in an osteosarcoma cell line SaOS-2, but its function is not known [15]. In the lung cancer cell line NCI-H460, EphA5 becomes localized to the nucleus in response to ionizing radiation (IR), where it binds to ATM to repair DNA damage, thereby preventing IR-induced cell death [16]. Lung cancer patients who fail to respond to radiation therapy have been shown to have significantly higher levels of EphA5 protein, so nuclear localization of EphA5 could have implications for 
prognosis and treatment options [16]. An antibody that inhibits translocation of EphA5 to the nucleus slowed tumor growth in a rat xenograft model of human lung cancer, identifying EphA5 as a target for therapeutic intervention [16]. EphB4 has been detected in the nucleus of two prostate cancer cell lines, LNCaP and DU145, where it bound to DNA and altered transcriptional levels of genes associated with more advanced prostate cancer [17]. It was not determined if EphB4 is directly or indirectly binding to DNA to alter transcriptional levels. Both EphA5 and EphB4 were in the nucleus as full-length polypetides $[16,17]$. While the trafficking mechanism of EphA5 is not known, EphB4 has a bipartite nuclear localization sequence and is translocated into the nucleus with importin- $\alpha$ [17].

In this study we investigated EphA1 nuclear localization in canine, mouse, and human RMS. EphA1 is localized to the nucleus in interphase cells but not dividing cells in tumors from all three species. In addition, EphA1 appears to be in the nucleus as a fulllength RTK that might be phosphorylated, indicating that EphA1 could be in the nucleus as an activated signal transducer. These data represent the first nuclear RTK in RMS and the first time that EphA1 has been detected in the nucleus of any cell type. Studies are ongoing to determine how nuclear EphA1 is involved in RMS.

\section{$\underline{\text { Results }}$}

\section{EphA1 is in the nucleus of primary canine RMS tumors}

In our initial screen for Ephs and their ephrin ligands that are expressed by RMS cells, we stained tumor samples identified as RMS by pathology after resection from two different companion dogs. One tumor was located in the nasal cavity and was surrounded 
by cartilage and mucosal tissue. The other was a limb tumor that was embedded in skeletal muscle. Both tumors were formalin fixed and paraffin embedded before sectioning. These sections were stained for Eph and ephrin proteins as well as for myogenin, a transcription factor expressed during myogenesis that is commonly used to diagnose RMS. Myogenin was not detectable in the limb tumor but was detected in a subset of cells in the nasal tumor. This finding is not unexpected as myogenin expression can vary widely between RMS tumors [18]. We noted that not only is EphA1 in particular localized to the nucleus of cells within the tumors, it was expressed in almost every cell. In addition, EphA1 immunopositivity is not uniform but is concentrated areas of the nucleus that appear to be regions of euchromatin, as indicated by less intense DAPI staining [19]. The intensity of EphA1 staining varies between cells in both tumors, which might be expected in a heterogenous population of cells in a tumor section [20]. In the nasal tumor, the cells with the strongest expression of EphA1 are also positive for myogenin. Myogenin staining is also localizing to particular subdomains of the nucleus, with a pattern that is the opposite of EphAl localization (Figure 3-1, nasal tumor inset). Staining for EphA1 in the limb tumor allowed us to make a direct comparison between EphA1 expression in RMS cells and in the normal skeletal muscle the tumor was embedded in. The surrounding muscle tissue was negative for EphA1 expression, even at the cell surface (Figure 3-1). This suggests that EphA1 expression as well as localization differs between cancer cells and healthy tissue.

\section{Eph and ephrin expression in mouse and human RMS cell lines}


In order to determine if EphA1 is also localized to the nucleus in RMS of other species, we examined EphA1 expression and localization in mouse and human RMS cell lines. While RMS is the most common soft tissue tumor in children, it is still a relatively rare cancer as only 350 new cases are diagnosed every year in the United States [2]. The rarity of RMS diagnosis adds a significant obstacle to obtaining human primary tumor samples, so work in these species was done in cell lines created from RMS tumors. Three cell lines amplified from RMS tumors are the specimens used in the majority of work done in human. Rh18 is an ERMS cell line developed from a tumor originating in the perineum [21, 22]. Rh30 is an ARMS cell line developed from a tumor originating in the posterior fossa and Rh41 is an ARMS cell line from a lung tumor [22, 23]. Mouse RMS cell lines were derived from primary or metastatic tumors in transgenic mice designed to develop ERMS or ARMS. Cell lines U23674 and U48484 are models of the ARMS subtype as they are derived from mice with forced expression of the Pax3-FOXO1 fusion protein [24]. Cell lines U33915 and U57810 are models of the ERMS subtype, which does not express the fusion protein but instead is driven by mutations to PTCHI and TP53 in a muscle specific fashion [25]. The importance of these pathways in ERMS and ARMS is discussed in Chapter 1.

We detected nuclear EphA1 staining in all four mouse cell lines (Figure 3-2 A). As in the canine tumors, EphA1 expression is not diffusely spread throughout the nucleus. Instead, it is detected in regions where the DAPI staining is less intense, indicating again that EphA1 could be localizing specifically to regions of euchromatin rather than heterochromatin. While nuclear EphA1 was present in all cell lines, the intensity of EphA1 staining varied between cells and between cell lines. Variation 
between cells in the same cell line is not surprising as these cells are generated from mouse tumors, which are a heterogenous population of cells. Overall, EphA1 appeared to have the lowest expression in U48484, which is the only mouse cell line derived from a metastatic tumor. This could indicate that EphA1 protein expression varies during tumor progression.

While almost every cell expressed EphA1 in the nucleus, there were a few cells where it no longer colocalized with DAPI. These cells all appeared to be mitotic cells (Figure 3-2A, asterisks). Expression of EphA1 is maintained in these cells, but it is now detected diffusely throughout the cell rather than exclusively in DAPI-stained regions. This observation has several implications. First, the EphA1 antibody is not binding nonspecifically to DAPI stained regions as EphA1 is detected diffusely throughout the cell in dividing cells. Second, EphA1 localization might be correlated with the cell cycle, shuttled away from and back to the DNA at particular points.

Staining for EphA1 expression revealed that all three human RMS cell lines exhibited nuclear localization of EphA1 (Figure 3-2B). As noted in canine primary tumors and mouse cell lines, EphA1 is localized to particular regions in the nucleus which have the histological appearance of euchromatin. As seen in the mouse cell lines, colocalization with DAPI was lost in dividing cells (Figure 3-2B Rh18). In mitotic cells, EphA1 expression is detected throughout the cell rather than in the nucleus. Detection of nuclear EphA1 in RMS from all three species suggests that this atypical localization may contribute to RMS formation or progression that is not dependent on subtype.

\section{EphA1 is localized differentially in distinct phases of the cell cycle.}


While nearly all interphase cells exhibit colocalization of EphA1 and DAPI staining, in mitotic cells EphA1 expression was diffuse throughout the cell (Figure 3-2, asterisks). To investigate if EphA1 localization is altered in specific phases of the cell cycle, we co-stained mouse cell line U23674 for EphA1 and phospho-histone H3 (PH3), a marker of proliferating cells. PH3 has a distinct appearance as a cell passes through each phase of the cell cycle, simplifying identification of mitotic cells. Histone $\mathrm{H} 3$ serine 10 phosphorylation is at high levels from prophase through metaphase but drops during anaphase and is barely detectable or absent during telophase [26]. Using this information, we were able to identify cells in different phases of the cell cycle.

When RMS cells first enter the cell cycle in prophase, EphA1 colocalizes with DNA staining, indicating that it is still restricted to the nucleus (Figure 3-3, Panel 2). Shortly after prophase but before metaphase, EphA1 is no longer colocalized with DNA and instead is detected diffusely throughout the cell (Figure 3-3, panel 3). This diffuse localization is maintained through the rest of mitosis and cytokinesis (Figure 3-3, Panels 4 and 5). Following exit from mitosis, EphA1 is again restricted to the nucleus and colocalizes with DAPI (Figure 3-3, Panel 6). This suggests that EphA1 is actively shuttled between cellular compartments during specific phases of the cell cycle, although alternatively it is possible that the protein in the nucleus is degraded just prior to mitosis followed by de novo synthesis and nuclear localization in the daughter cells.

\section{EphA1 is in the nucleus as a full-length receptor}

The portion of an RTK that is trafficked to the nucleus can have implications for its function as evidenced by the ErbB family. When full-length ErbB members are 
trafficked to the nucleus, they have pro-tumorigenic roles including increased cell proliferation, angiogenesis, and metastatic potential mediated through regulating gene expression and interactions with other nuclear proteins [9, 27, 28]. If an intracellular cleavage fragment is trafficked to the nucleus instead, it has anti-tumorigenic roles as it is associated with growth suppression through indirect transcriptional regulation $[9,14]$. Our staining data localizes EphA1 to the nucleus, but because the antibody we initially validated is raised to the intracellular, C-terminal end of the protein we could not use immunohistochemistry to differentiate between full-length and cleaved or truncated protein. To determine if EphA1 is in the nucleus as an intracellular fragment or a fulllength receptor, we isolated nuclear fractions and cytoplasmic fractions as well as whole cell lysate from mouse RMS cell lines and performed Western blots. The EphA1 band detected in the nuclear fraction and whole cell lysate have the same apparent molecular weight, suggesting that EphA1 in the nucleus is a full-length polypeptide rather than a smaller fragment (Figure 3-4A). To confirm this result, we acquired an antibody raised to the N-terminal end of EphA1 (Santa Cruz) and stained fixed RMS cells. We again noted that EphA1 immunopositivity was localized to the nucleus (Figure 3-4B). Detection of both C-terminal and N-terminal epitopes of EphA1 in the nucleus combined with the Western blot data led us to conclude that EphA1 exists in the nucleus of RMS cells as a full-length polypeptide.

Interestingly, no EphA1 was detectable in the cytoplasmic fraction (Figure 3-4A). The EphA2 band was detected in the cytoplasmic rather than the nuclear fraction, indicating that membrane-bound, surface proteins are detected in the cytoplasmic fraction (Figure 3-4A). This is consistent with the localization pattern we observed in our 
immunostaining data in which EphA1 expression was exclusively localized to the nucleus in all but dividing cells. This could have implications for the mechanism of EphA1 nuclear import. During importin-mediated nuclear import, nuclear proteins are recognized by an importin in the cytoplasm before translocation through nuclear pores [29]. Rather than starting at the plasma membrane and retrograde trafficking to the nucleus, EphA1 may never reach the plasma membrane. To test whether EphA1 is ever present at the plasma membrane in RMS cell lines, we used the N-terminal antibody to screen for EphA1 expression in cells that had not been permeabilized, thereby preventing detection of any intracellular protein. No EphA1 expression was detected in unpermeabilized cells (Figure 3-4B). This unusual result suggests that EphA1 is not at the plasma membrane, indicating that it may be trafficked to the nucleus by a unique mechanism that varies from that of other RTKs in the nucleus such as ErbB1 and EphB4.

While EphA1 has previously never been detected in the nucleus, using the nuclear localization sequence (NLS) prediction software NLS Mapper (http://nlsmapper.iab.keio.ac.jp/cgi-bin/NLS_Mapper_form.cgi) we do identify a bipartite NLS with a long linker starting at position 867 , which overlaps with the kinase domain on the intracellular portion of the receptor. This type of NLS is usually recognized by importin$\alpha$ for nuclear import, providing a possible mechanism for nuclear import of EphA1.

The activation status of nuclear EphA1 could have implications for its function in the nucleus, as RTKs are often phosphorylated on tyrosine residues which leads to their activation and facilitates their binding and activation of downstream effectors. To determine if EphA1 is phosphorylated in the nucleus, we immunoprecipitated with an EphA1 antibody and then performed a western blot with an anti-phosphotyrosine 
antibody. A band corresponding to full-length EphA1 was detected in all four cell lysates, suggesting that at least a fraction of the protein has been phosphorylated (Figure 3-4C). While these lysates were whole cell lysates rather than fractionated lysates, lack of any detectable expression in cytoplasmic fractions suggests that we have detected nuclear EphA1 in this experiment. This suggests that EphA1 is in the nucleus as a phosphorylated, full-length RTK that could be capable of phosphorylating other proteins in the nucleus.

\section{Investigating roles for EphA1 in the nucleus of RMS cells}

Based on what is known of other nuclear RTKs in cancer, the most probably activities for nuclear EphA1 in RMS cells would be either interacting with nucleic acids (directly or indirectly) or by alternatively might be interacting with (and possibly phosphorylating) nuclear proteins. To determine if EphA1 is binding to specific regions of DNA, we used chromatin immunoprecipitation and sequencing (ChIP-seq) on PFA fixed mouse RMS cells. Our initial attempt to precipitate endogenous protein was not efficient, with the same antibody used for staining and Western blot did not yield high levels of EphA1 from the nucleus. We therefore generated an expression vector to produce an exogenous EphA1 in which the C-terminal, intracellular end of EphA1 was tagged with a short peptide sequence, the AM-tag, which could be used to specifically pull down the tagged protein. In-Fusion HD Cloning was used to clone EphA1 into pAM-1C (Active Motif), using site directed mutagenesis to change the stop codon to alanine. After sequencing the plasmid to confirm that the AM-tag was in-frame with EphA1, it was transfected into the ARMS cell line U48484 using polyethylenimine (PEI). 
Stable cell lines were isolated by 10 days of puromycin selection and cloning of the surviving individual colonies. Twelve colonies were picked and screened for expression of EphA1-AM by subcellular fractionation and Western Blotting. Endogenous EphA1 expression was detected in nuclear and whole cell lysate, but EphA1-AM was not detectable in any of the stable colonies (Figure 3-5A).

Because the cell lines did not express EphA1-AM, we returned to the original antibody to pull down EphA1 protein and generate samples for ChIP-seq analysis to discover potential DNA interactions and liquid chromatography-mass spectrometry (LCMS) to detect interactions with other nuclear proteins. EphA1 has not been detected in the nucleus before this, so no antibodies validated for use in ChIP-seq are available. To test suitability of the Santa Cruz EphA1 antibody (sc-925) for ChIP-seq, RMS cell samples were submitted to Active Motif for an antibody test. While samples yielded enough chromatin, immunoprecipitation with the EphA1 antibody did not yield any sequences that were significantly different from input controls processed with no antibody, indicating that it would not be suitable for ChIP-seq analysis. The same antibody was used for EphA1 immunoprecipitation from nuclear fractions of formaldehyde-fixed mouse RMS cell lines. Silver staining indicated that protein was present in immunoprecipitates from all four mouse cell lines (Figure 3-5 B). To identify any proteins that co-immunoprecipitated with EphA1, samples were analyzed by LC-MS at the Charles W. Gehrke Proteomics Center at the University of Missouri. Despite detecting proteins through silver staining, no enriched proteins were identified by LCMS. 
Attempts to isolate EphA1 through immunoprecipitating native or tagged protein were unsuccessful, so we attempted a third tactic. We reasoned that the lack of expression of exogenous, tagged EphA1 in our stable colonies might indicate that either the levels of expression from a transfected plasmid or expression of the AM-tagged EphA1 are toxic. We therefore cloned EphA1 into a vector with an inducible promoter, pcDNA4/TO/mycHis, which allows us to separate transfection with the tagged EphA1 vector from expression of the tagged protein. When co-transfected with the pcDNA6-TR plasmid, tagged EphA1 will only be expressed when tetracycline is added to the media and removes the Tet repressor from the Tet operator. If expression of myc-His-tagged EphA1 is toxic to cells, they won't die until exposed to tetracycline, and we should be able to induce expression, then rapidly collect the samples and test for EphA1 interactions. Stable cell lines were isolated by 12 days of blasticidin and zeocin selection and cloning of the surviving individual colonies. Five colonies were then treated with either a low dose $(0.5 \mu \mathrm{g} / \mathrm{mL})$ or a high dose $(1 \mu \mathrm{g} / \mathrm{mL})$ of tetracycline for 24 hours. Cells were harvested and fractionated into nuclear, cytoplasmic, and whole cell lysate then loaded on a column with ProBond nickel-chelating resin to bind EphA1-myc-His. The proteins bound to the columns were then analyzed by Western Blot.

In two of the stable lines, clones 4 and 5 , there were distinct differences in band patterns between samples treated with or without tetracycline to induce EphA1-myc-His expression (Figure 3-6B). In particular, a pair of bands is detected in samples from clone 5 treated with a low dose of tetracycline but not in the untreated sample. These bands also appear in the sample treated with higher levels of tetracycline but are weaker, indicating that the low dose might be better for use in further experiments (Figure 3-6 B). Western 
blots of nickel-resin pull downs from nuclear fractions were consistent with those from whole cell lysates. EphA1 was detected in every sample except samples isolated from from clone 1 that were either untreated or low-dose tetracycline treated (Figure 3-6 A). There is a significant band strength increase in clone 3 treated with a high dose of tetracycline compared to untreated or low dose treated. There were no differences in treatments with clonal lines 2, 4, or 5 (Figure 3-6 A). While these data indicate that nuclear EphA1-myc-His is upregulated in tetracycline-treated cells in clonal lines 1 and 3, it is also detected in untreated samples that should not express any EphA1-myc-His and therefore should not pull-down with nickel-chelating resin beads. Further work should be done to verify that this conditional expression system has successfully solved the problem of exogenous/tagged EphA1 toxicity before it is used to repeat the ChIP-seq and LC-MS analysis.

The ability to efficiently isolate EphA1 and interacting components from nuclear fractions is critical for the necessary experiments, but there is no antibody validated for isolating nuclear EphA1. Given the results obtained from fluorescent immunocytochemistry and Western blotting, we proceeded with analysis using the EphA1 antibody from Santa Cruz Biotechnology for immunoprecipitations. However, ChIP-seq and LC-MS analysis both failed with this method, indicating that the EphA1 antibody is not efficiently immunoprecipitating nuclear EphA1. To circumvent this obstacle, we decided to try isolating tagged EphA1 instead of the endogenous protein. The first tag we added was the AM-tag from active motif. Stable cell lines transfected with the EphA1-AM plasmid were created indicating that transfection was successful. However, we were unable to detect expression of EphA1-AM in any of the stable lines 
(Figure 3-5 A). This indicates that the cells that survived to produce colonies likely received empty plasmid. Sequencing of the plasmid confirmed that the EphA1 sequence was in the plasmid and in frame with the AM tag, leaving two possibilities for absence of expression of EphA1-AM. The cells might not be expressing EphA1-AM even if they received plasmid, or expression of EphA1-AM is toxic for RMS cells.

If expression of tagged EphA1 is toxic for RMS cells, an inducible expression system could solve this technical problem. The T-REx System from Invitrogen is a tetracycline-regulated expression system in which cells are co-transfected with pcDNA6/TR encoding the Tet repressor and pcDNA4/TO/myc-His which has the Tet operator that blocks expression of the myc-His-tagged protein when the Tet repressor is present. Upon incubation with tetracycline, the Tet repressor dissociates from the operator and the tagged protein is expressed. Stable cell lines were generated from cotransfected cells and incubated with low and high doses of tetracycline to induce expression of EphA1-myc-His, and Western blots were used to verify expression. Initial experiments indicated the induction of EphA1-myc-His in treated cells, with the low-dose of tetracycline inducing higher levels of expression (Figure 3-6 B). When we moved to analyzing EphA1-myc-His in nuclear fractions, expression was induced upon tetracycline treatment in two of the stable cell lines but was also present in the untreated samples (Figure 3-6 A). This could indicate that EphA1-myc-His is not toxic to RMS cells and may be a viable solution for future experiments. However, expression in untreated samples suggests that the system needs to be optimized for these cell lines before they can be used in ChIP-seq and LC-MS analysis. 
The ratio of Tet repressor to Tet operator is a crucial factor in repressing expression in the T-REx system. If there is not enough Tet repressor to bind to all of the Tet operators, there could be low levels of basal expression in cells that have not been treated with tetracycline. Low levels of Tet repressor may explain detection of EphA1$m y c-$ His in the stable cell lines that were generated. Repeating the transfection protocol with a higher ratio of pcDNA6/TR to pcDNA4/To/EphA1-myc-His could resolve this issue. Another cause of of EphA1-myc-His expression in untreated samples could be tetracycline in the Fetal Bovine Serum (FBS) used to culture the cells. Different lots of FBS could have variable levels of tetracycline, so batch testing FBS to find the optimal conditions could also reduce expression in untreated samples. Once EphA1-myc-His inducible expression conditions have been optimized, isolation with nickel-chelating resin beads should be performed again and the resultant samples should be analyzed with LCMS to identify proteins in complex with EphA1 and ChIP-seq to identify any DNA sequences it interacts with. A combination of these approaches will yield significant insights into the role of EphA1 in the nucleus of rhabdomyosarcoma cells.

\section{$\underline{\text { Discussion }}$}

Many RTK families are translocated to the nucleus as either an intact, full-length receptor or intracellular cleaved fragment in various forms of cancer including ErbB2 in breast cancer, FGFR1 in medulloblastoma, and VEGFR1 in lymphoma [8]. This study adds EphA1 to the list of RTKs in the nucleus. We detected nuclear expression in RMS of three species: canine, mouse, and human. While the mouse cell lines were derived from transgenic mice with RMS-causing mutations, the human cell lines and canine 
primary tumor samples indicate that nuclear localization of EphA1 occurs in sporadic tumors and is not an artifact of how the mice were designed. In addition, the canine limb tumor was imbedded in skeletal muscle, allowing us to compare expression of EphA1 in RMS and skeletal muscle directly. EphA1 was not detected in surrounding skeletal muscle, indicating that the expression and atypical localization is unique to RMS and represents a difference between normal and tumor tissues. EphA1 expression has been detected in mouse primary satellite cells: 50\% of mouse satellite cells expression EphA1 at the cell surface [30]. This is different from the canine tissue, but EphA1 expression in mouse RMS cells is still increased and localized to the nucleus rather than the plasma membrane. In addition, the conserved atypical localization across the three species suggests that it could have integral roles to RMS formation or progression.

Expression of EphA1 is not diffuse throughout the nucleus. Instead, it is localized to regions where DAPI staining is less intense, indicating that it is localized to the euchromatin rather than the heterochromatin. This could have implications for its function. There are two potential activities EphA1 could have in the nucleus: transcription regulation and signal transduction. Euchromatin localization would be consistent for a protein acting as a transcription factor, which makes gene regulation a strong possibility for EphA1.

In the ErbB family, the portion of the RTK that is translocated to the nucleus might have implications on its function, where full-length ErbB receptors are tumorigenic but intracellular fragments are anti-tumorigenic. As indicated by the Western blot (Figure $3-4 \mathrm{~A})$, EphA1 is in the nucleus as a full-length protein. If behaving similarly to nuclear ErbB, this could implicate EphA1 in RMS formation or progression. The mechanism of 
full-length ErbB has been well described. After activation with EGF, it is endocytosed into vesicles where it associates with importin- $\beta$. Then it travels back through the Golgi and endoplasmic reticulum to the nuclear membrane, where it travels through nuclear pores and is released from the membrane into the nucleoplasm by Sec61 [31]. As seen in Figure 3-4, our data indicates that EphA1 never makes it to the plasma membrane. This indicates that it may not be activated at the cell surface by an ephrin, in which case it must differ at least partly from ErbB in its translocation pathway.

Three other Eph receptors have been detected in the nucleus of cancer cell lines. EphA4 was detected in the nucleus of an osteosarcoma cell line, but its function is not known [15]. EphA5 was detected in the nucleus of lung cancer cell lines in response to ionizing radiation (IR), where it binds to ATM to repair DNA damage, preventing IR induced cell death [16]. EphB4 was detected in the nucleus of prostate cancer cell lines, where it bound to DNA and altered transcriptional levels of genes associated with more advanced prostate cancer [17]. Both EphA5 and EphB4 were in the nucleus as full-length receptors $[16,17]$. While the trafficking mechanism of EphA5 is not known, EphB4 has a bipartite nuclear localization sequence and is translocated into the nucleus with importin$\alpha$. As EphA1 has a similar NLS, it might also be imported by importin- $\alpha$ [17]. However, EphA5 and EphB4 are both detected at the plasma membrane and in the cytoplasm of lung cancer and prostate cancer cells, respectively. Because EphA1 was not detected in the cytoplasm or the plasma membrane (Figure 3-4), EphA1 could be using an entirely different transport mechanism than EphB4 to localize in the nucleus. Transmembrane proteins such as RTKs are synthesized at the endoplasmic reticulum where they are glycosylated and trafficked to the plasma membrane [32]. It is possible that EphA1 is not 
glycosylated and therefore never trafficked out of the ER to the plasma membrane, but instead interacts with Sec61 on the ER membrane as ErbB1 does to be translocated into the nucleus.

To our knowledge, this is the first nuclear RTK to be identified in RMS and is also the first time that EphA1 has been detected in the nucleus. While our attempts to identify specific activities of nuclear EphA1 were not successful, based on our current understanding, based on our current understanding of RTKs the nucleus, (primarily ErbB, EphA5, and EphB4), we still hypothesize that EphA1 could be playing an important role in tumorigenesis. Possible activities could include altering transcription of particular genes, increasing therapy resistance by promoting DNA damage repair, or promoting DNA replication and cell proliferation. EphA1 does appear to be phosphorylated in the nucleus, which could suggest a role for protein interactions and signal transduction if this phosphorylation has activated the kinase domain (Figure 3-4 C). It is more likely that it is regulating transcription in the nucleus given the vast majority of nuclear RTKs functioning this way and that it is localized to euchromatin, which is where transcription occurs (Table 1 and Figures 3-1, 3-2, 3-3). Further studies need to be done to determine which tyrosine residue is phosphorylated and if EphA1 is interacting with nucleic acids like EphB4 in prostate cancer, other nuclear proteins like EphA4 in lung cancer, or some combination of the two. 


\section{Materials and Methods}

\section{Cell culture and samples}

Canine tumor samples were graciously donated by Dr. Jeffrey Bryan at the University of Missouri School of Veterinary Medicine. They were isolated from tumors located in the nasal cavity and the limb of two different dogs. Tumors were formalinfixed and paraffin embedded before sectioning. Mouse rhabdomyosarcoma cell lines were graciously provided by Dr. Charles Keller. These cell lines were generated from tumors in transgenic mice with the following mutations to cause RMS: U23674 (Myf6Cre/Pax3-Foxo1/p53 ${ }^{-/-}$), U33915 (Pax7CreER, Ptch1, p53 ${ }^{-/}$), U48484 (Myf6Cre/Pax3-Foxo1/p53---), U57810 (Myf6Cre/p53 ${ }^{--}$). Mouse RMS cell lines are cultured in DMEM (Gibco) with 10\% Fetal Bovine Serum (Sigma) and 1\% penicillin/streptomycin (Sigma) at $37^{\circ} \mathrm{C}$ and $5 \% \mathrm{CO}_{2}$ in a humidified incubator (Heracell 150, Heraeus). Human RMS cell lines Rh18, Rh30, and Rh41 come from the Children's Oncology Group at Texas Tech University. Human cell lines were grown in Iscove's Modified Dulbecco's Medium (Gibco) plus 20\% Fetal Bovine Serum, 4 mM L-glutamine (Sigma), 1 x Insulin-Transferrin-Selenium (Corning) and 1\% penicillin/streptomycin at $37{ }^{\circ} \mathrm{C}$ and $5 \% \mathrm{CO}_{2}$ in a humidified incubator.

\section{Immunofluorescence}

For fluorescent immunocytochemistry of cultured RMS cells, mouse cell lines were plated onto glass coverslips (Corning) coated with $6.6 \%$ gelatin (USB corporation) and allowed to adhere at least overnight. Human RMS cell lines were plated onto glass coverslips coated with poly-L-lysine (Invitrogen). Coverslips were fixed in cold 4\% paraformaldehyde (Fisher) for 10 minutes on ice. Cells were blocked in 10\% normal goat 
serum (Sigma) with 1\% Nonidet-P40 (USB Corporation) for 1 hour at room temperature for all primaries except for those raised in goat, in which case cells were blocked with $20 \%$ BlokHen (Aves Labs) for 1 hour at room temperature. Cells were then incubated with primary antibody overnight at $4^{\circ} \mathrm{C}$, washed, incubated with secondary antibody for 1 hour at room temperature, and washed again. Cells were then stained with Alexa 488labeled phalloidin (Invitrogen) diluted 1:20 from a stock solution of $6.6 \mu \mathrm{M}$ into PBS and incubated at room temperature for 30 minutes. Cells were then washed and mounted in Vectashield containing DAPI (Vector Labs).

Canine tumor sections first had to deparaffinized using three changes for 5 minutes each n xylene-substitute Histo-Clear (National Diagnostics). Sections were then rehydrated by washing twice in $100 \%$ ethanol (Fisher) for 10 minutes each then $95 \%$ ethanol for 10 minutes followed by a 1-minute wash in deionized water with stirring. Excess liquid was aspirated and then were processed for antigen retrieval. First, cells were rinsed 3 times in PBS for 5 minutes. Then cells were rinsed in $10 \mathrm{mM}$ citrate buffer (1.8 $\mathrm{mM}$ citric acid (Fisher), $8.2 \mathrm{mM}$ sodium citrate (Fisher)) for 5 minutes. Citrate buffer was replaced, and the sections were placed in the Antigen Retriever (Aptum Biologics) for retrieval. After the retrieval cycle finished and sections had cooled, they were rinsed 3 times with deionized water then PBS for 15 minutes. After this, sections were blocked and stained as described above for the coverslips.

Primary antibodies (Santa Cruz unless otherwise noted) and dilutions were:

EphA1 1:200, N-terminal EphA1 1:100, EphA2 1:200, EphA3 1:200, EphA4 1:200, EphA7 1:300, EphA8 1:200, EphB1 1:200, EphB2 1:200, EphB4 1:200, EphB6 1:200 (AbCam), ephrin-A1 1:200, ephrin-A2 1:200, ephrin-A3 1:200, ephrin-A4 1:200, ephrin- 
A5 1:200 (AbCam), ephrin-B1 1:200, ephrin-B3 1:300, PH3 1:100. Secondary antibodies were raised in goat and conjugated with Alexa fluorophores (Invitrogen) and used at 1:500 dilution. All images were acquired and processed on an Olympus BX61 upright microscope using Slidebook software (Intelligent Imagine Innovations) or $\mu$ Manager software (www.micro-manager.org). Digital background subtraction was performed to remove signal that was less than or equal to levels present in control samples (processed with primary antibody only) and was applied equally to the entire field.

\section{Surface EphA1 stain}

RMS mouse cell line U23674 was plated on glass coverslips coated with gelatin and allowed to adhere for at least 12 hours. Unfixed cells were rinsed 2 times in cold DPBS then blocked with BlokHen diluted 1:5 for 5 minutes at $4^{\circ} \mathrm{C}$. Coverslips were then incubated with N-terminal EphA1 primary antibody (Santa Cruz) diluted at 1:100 for 30 minutes at $4^{\circ} \mathrm{C}$ and washed 3 times with PBS for 5 minutes each at $4^{\circ} \mathrm{C}$. Cells were then fixed with 4\% PFA for 10 minutes on ice, then washed 3 times with PBS for 5 minutes then incubated with an Alexa 488-conjugated anti-goat secondary antibody (Invitrogen) diluted at 1:500. Cells were imaged and processed as described above.

\section{Collecting cell lysates}

Unfractionated samples were collected by lifting cell cultures with trypsin (Corning), centrifuged at $200 \mathrm{xg}$ for 5 minutes at $4^{\circ} \mathrm{C}$ to pellet, resuspended in DPBS to wash, and pelleted at $200 \mathrm{xg}$ for 5 minutes at $4^{\circ} \mathrm{C}$. If not used immediately, cell pellets were frozen and stored at $-80^{\circ} \mathrm{C}$. Cell pellets were then resuspended in Allen buffer (50 mM Tris pH 7.4 (Fisher), 10 mM EDTA (Acros), 5 mM EGTA (Acros), 1 x Roche Protease Inhibitors (Roche), $1 \mathrm{mM} \mathrm{NaVO}_{4}$ (MP Biomedicals), $2.0 \mathrm{mM} \mathrm{NaF}$ (Fisher), 1 
$\mu \mathrm{g} / \mu \mathrm{L}$ pepstatin A (Sigma), $1 \%$ TritonX-100 (Fisher)), homogenized by 5 passages through a 30-gauge needle, and centrifuged for 10 minutes at $10,000 \mathrm{x}$ g at $4^{\circ} \mathrm{C}$. Supernatant was collected and protein quantification was determined via a Bradford protein assay with the Bio-Rad Protein Assay Dye Reagent Concentrate (Bio-Rad). Protein lysates were stored at $-80^{\circ} \mathrm{C}$ until needed.

\section{Subcellular fractionation}

Subcellular fractionation to isolate nuclei from the cytoplasm was performed based on a previously published method and briefly described below.[33] RMS mouse cell lines were grown to near confluency, washed twice in cold DPBS, and collected in 1 $\mathrm{mL}$ of cold DPBS using a plastic cell scraper. Samples were briefly spun for 10 seconds in an USA Scientific Micro Centrifuge. Supernatant was removed and cells were resuspended in $900 \mu \mathrm{L}$ ice-cold $0.1 \%$ NP-40 in PBS and triturated 5 times with a p1000 micropipette. $300 \mu \mathrm{L}$ was removed to be the "whole cell lysate" and stored on ice. Leftover sample was briefly spun for 10 seconds. $300 \mu \mathrm{L}$ was removed to be the "cytosolic fraction" and stored on ice. Remaining supernatant was removed and pellet was resuspended in $900 \mu \mathrm{L}$ ice-cold $0.1 \%$ NP-40. Samples were briefly spun for 10 seconds and supernatant was discarded. Pellet was resuspended in $135 \mu \mathrm{L}$ ice-cold $0.1 \%$ NP-40 to be the "nuclear fraction" and stored on ice. Roche Protease Inhibitor Cocktail (Roche) was added to each of the samples and the nuclear fraction and whole cell lysate were passed through a 30-gauge needle (BD PrecisionGlide) to break open nuclei. All lysates were stored at $-80^{\circ} \mathrm{C}$ until needed. 


\section{Immunoprecipitation}

Immunoprecipitation was preformed using PureProteome Protein A Magnetic Beads (Millipore) following the manufacturer protocol. For the EphA1-IP followed by blotting for phosphotyrosine, $0.4 \mu \mathrm{g}$ of EphA1 antibody (Santa Cruz) was used for immunoprecipitation from $10 \mu \mathrm{g}$ of total protein from U23674. Antibody was preincubated with beats for 10 minutes at room temperature with agitation. Antibody-bound beads were incubated with protein lysates for 2 hours at $4^{\circ} \mathrm{C}$ with agitation. Bound protein was eluted into $1 \mathrm{M}$ Tris (Fisher), pH 7.4 with Roche Protease Inhibitor Cocktail and boiled for 10 minutes. IPs were stored at $-80^{\circ} \mathrm{C}$.

For LCMS analysis, $6 \mu \mathrm{g}$ EphA1 antibody was used for immunoprecipitation from up to $300 \mu \mathrm{g}$ nuclear proteins from all four mouse RMS cell lines. Antibody was pre-incubated with beads overnight at $4^{\circ} \mathrm{C}$ with agitation. Antibody-bound beads were incubated with protein lysates overnight at $4{ }^{\circ} \mathrm{C}$ with agitation and eluted by boiling for 10 minutes in SDS-sample buffer without dye (80 mM 1M Tris $\mathrm{pH}$ 6.8, 2\% SDS, 10\% Glycerol (Fisher), 0.1 M DTT (Acros). IPs were stored at $-80^{\circ} \mathrm{C} .5$ replicate immunoprecipitations were performed for each cell line.

\section{Western blot}

6x Laemmli buffer (60 mM 1.5M Tris-Cl pH 6.8 (Fisher), 10\% glycerol (Fisher), $2 \%$ sodium dodecyl sulfate (Fisher), 5\% $\beta$-mercaptoethanol, $0.01 \%$ bromophenol blue (JT Baker)) was added to fractionated U23674 cell lysates equivalent to $2 \times 10^{5}$ cells and boiled for 10 minutes. Samples and ladder (PageRuler Prestained Protein Ladder, Thermo Scientific) were loaded on to a $10 \%$ polyacrylamide gel, run at $130 \mathrm{~V}$, then transferred to a PVDF membrane. Membranes were blocked for 1 hour at room temperature in 
StartingBlock (TBS) Blocking Buffer (Thermo Scientific) while rolling. Primary antibody was diluted in StartingBlock and incubated with membrane overnight while rolling at $4^{\circ} \mathrm{C}$. Membranes were then washed 3 times in TBST $(19 \mathrm{mM}$ Tris $\mathrm{pH} 7.4$ (Fisher), $137 \mathrm{mM} \mathrm{NaCl}$ (Fisher), $2.7 \mathrm{mM} \mathrm{KCl} \mathrm{(Fisher),} \mathrm{0.05 \%} \mathrm{Tween-20} \mathrm{(Sigma))} \mathrm{for} 20$ minutes each at room temperature. Secondary antibody was diluted in StartingBlock and incubated for one hour at room temperature with rolling. Membranes were then washed 3 times in TBST for 20 minutes with rolling. Visualization was completed with SuperSignal West Femto Maximum Sensitivity Substrate (Thermo Scientific).

Chemiluminescence was detected using a LAS3000 imager (Fujifilm). Primary antibodies and dilutions used were EphA1 1:1000 (Santa Cruz), EphA2 1:1000 (Santa Cruz), tubulin 1:1000 (Chemicon), and phosphotyrosine 1:1000 (Upstate). Secondary antibodies used were goat anti-rabbit HRP 1:50,000 (Santa Cruz) and goat anti-rat HRP 1:10,000 (Pierce).

\section{Silver Stain}

$6 \mu \mathrm{L}$ from each replicate-IP was pooled and $4 \mu \mathrm{L}$ Laemmli buffer was added before boiling samples for 10 minutes. Samples were run on a 4-20\% Mini-PROTEAN TGX Precast Gel (BioRad) at $150 \mathrm{~V}$ for 35 minutes. The gel was carefully removed from the mold and fixed in $180 \mathrm{~mL}$ methanol (Fisher), $20 \mathrm{~mL}$ acetic acid (Fisher), and $180 \mathrm{~mL}$ distilled water for 20 minutes at room temperature. Gel was washed in water for 2 hours at room temperature, changing water every 30 minutes. The gel was then incubated in sensitizing solution ( $0.02 \%$ sodium thiosulfate (Fisher)) and wash in water twice for 1 minute each. After this, the gel was incubated in a silver nitration solution $(0.1 \%$ silver nitrate) for 20 minutes at room temperature then washed in water twice for 1 minute each. 
The gel was developed in developing solution ( $0.04 \%$ formalin (Fisher), $2 \% \mathrm{Na}_{2} \mathrm{CO}_{3}$

(Fisher)) until desired darkness has been reached, usually a few minutes. Developing was stopped by addition of $1 \%$ acetic acid and stored in fresh $1 \%$ acetic acid. The developed gel was imaged using a BioSpectrum 815 Imaging System (UVP).

\section{Preparing samples for LCMS analysis}

EphA1-IPs were thawed and 4 volumes (approximately $200 \mu \mathrm{L}$ ) of cold 100\% acetone (Fisher) was added. Proteins were precipitated by incubating samples at $-20^{\circ} \mathrm{C}$ overnight. Samples were then submitted to the Charles W Gehrke Proteomics Center for processing and analysis by LCMS on an LTQ Orbitrap XL (ThermoFisher).

\section{In-Fusion Cloning}

EphA1 was amplified from pCMV_Sport6 for insertion into pAM_1C or pcDNA4/TO/myc-His. Overlapping primers for In-Fusion cloning were designed with SnapGene to have at least 15 base pair overlap with the target plasmid and sequence for EphA1. The following primers were used: InF_AM_For

CGATCTAAGTAAGCTECCATGGAGCGGCGC, InF_AM_Rev GATCTTGGCAAAGCTTGGATGCTCGGTCCTTAAATCCTTGAAT, InF_MycHisA_EphA1_For CAGTGTGGTGGAATTCAGGTCCCGGCCGG, InF_MycHisA_EphA1_Rev

GATATCTGCAGAATTCTCGGTCCTTAAATCCTTGAATACTGCAGA. Underlined segments of the primers are complementary to sequences at the end of EphA1 while the other half is complementary to pAM_1C or pcDNA4/TO/myc-His. EphA1 was amplified 
by PCR with CloneAmp HiFi PCR premix (Takara Bio), $0.5 \mu \mathrm{L} 20 \mu \mathrm{M}$ primers, and 100 ng pSport6_EphA1.

Vectors were linearized by restriction digest. pAM_1C was linearized by FastDigest HindIII (Thermo) in FastDigest Buffer (Thermo) for 4 hours at $37^{\circ} \mathrm{C}$. pcDNA4/TO/myc-His was digested with Fast Digest EcoRI (Thermo) in FastDigest buffer (Thermo) for 1 hour at $37^{\circ} \mathrm{C}$. Digests and PCR products were purified with the GeneJET PCR Purification Kit (Thermo). The In-Fusion reaction was completed following protocol from manufacturer using $100 \mathrm{ng}$ purified PCR product and $100 \mathrm{ng}$ linearized vector. Reactions were stored at $-20^{\circ} \mathrm{C}$ until use.

\section{Bacterial Transformation}

Stellar competent cells (ClonTech) were thawed on ice, then $50 \mu \mathrm{L}$ were transferred to $14-\mathrm{mL}$ round bottom culture test tubes (Fisher). $2.5 \mu \mathrm{L}$ of In-Fusion reaction products were added and cell were kept on ice for 30 minutes, followed by heat shock in a $42^{\circ} \mathrm{C}$ waterbath for exactly 45 seconds. Cells were returned to ice for 2 minutes, then $450 \mu \mathrm{L}$ pre-warmed SOC medium (Takara) was added. Cultures were incubated for 1 hour at $37^{\circ} \mathrm{C}$ while shaking at $250 \mathrm{rpm} .100 \mu \mathrm{L}$ was plated on LBcarbenicillin plates (per $1 \mathrm{~L}$ use $10 \mathrm{~g}$ tryptone (Acros), $10 \mathrm{~g} \mathrm{NaCl}$ (Fisher), $5 \mathrm{~g}$ yeast extract (Acros), $15 \mathrm{~g}$ agar (Fisher), $0.1 \mathrm{mg} / \mathrm{mL}$ carbenicillin (Sigma), incubated overnight at $37^{\circ} \mathrm{C}$, and individual colonies were used for the QIAGEN Plasmid Maxi Kit. Plasmids were sequenced by Sanger sequencing at the University of Missouri-Columbia DNA Core to confirm that EphA1 was in-frame with either the AM-tag or the myc-His tag. 


\section{Transfecting RMS cells to generate stable cell lines}

pAM_1C_EphA1 was transfected into U48484 cells using polyethylenimine (PEI). PEI, plasmid DNA, and serum-free DMEM was brought to room temperature. 37 $\mu \mathrm{g}$ of DNA was mixed with $1 \mathrm{~mL}$ of DMEM and mixed. $21 \mu \mathrm{L}$ of PEI $(1 \mu \mathrm{g} / \mu \mathrm{l})$ was added, reagents were mixed and incubated for 15 minutes at room temperature. DNA/PEI mixture was then added to the media of cells and returned to the $37^{\circ} \mathrm{C}$ incubator. 24 hours later $1 \mu \mathrm{L} 10 \mathrm{mg} / \mathrm{mL}$ puromycin (Gibco) was added to the cells and cultured in these conditions for 10 days until colonies formed. 12 colonies were picked to expand in order to establish stable cell lines.

pcDNA6/TR and pcDNA4/TO/myc-His-EphA1 were transfected into U33915 cells using the Neon Transfection System (Invitrogen). Antibiotic-free DMEM with 10\% FBS pre-warmed in 6-well tissue culture plates (Nunc). The manufacturer protocol was followed for 6-well plates and adherent cells. Cells were co-transfected with $0.5 \mu \mathrm{g}$ of each plasmid using Optimization Protocol 19 (pulse voltage 1050, pulse width 30, pulse number 2). Transfected cells were added to pre-warmed media and the plate was returned to the $37^{\circ} \mathrm{C}$ incubator. 4 hours later media was switched to DMEM with $10 \%$ FBS with 1\% Antibiotic-Antimycotic (Gibco). Three days later, $2 \mu 1$ 10mg/mL Blasticidin (Gibco) and $8 \mu \mathrm{L} 100 \mathrm{mg} / \mathrm{mL}$ Zeocin (Invitrogen) was added to the media and cells were cultured for 10 days. 10 colonies were picked and expanded to establish stable cell lines.

\section{Tetracycline Treatment}

Stable cell lines were cultured the same way as untransfected cells, described above. Tetracycline (Invitrogen) treatment was performed for 24 hours at $37^{\circ} \mathrm{C}$ in a 
humidified cell culture incubator at a low-dose $(0.5 \mu \mathrm{g} / \mathrm{mL}$ final concentration $)$ and a high-dose $(1.0 \mu \mathrm{g} / \mathrm{mL}$ final concentration). Cell lysates were then collected as above for subcellular fractionation.

\section{ProBond Resin Nickel-Chelating Resin pull down}

ProBond Resin beads (Invitrogen) were resuspended its bottle by inverting and gently tapping the bottle repeatedly. $50 \mu \mathrm{l}$ per pull down were pipetted into a $1.5 \mathrm{~mL}$ tube and gently pellet by low-speed centrifugation for 1 minute at $800 \mathrm{x}$ g. Supernatant was removed by pipetting and resuspended in $500 \mu \mathrm{L}$ of distilled water. Beads were pelleted by centrifugation for 1 minute at $800 \mathrm{x} g$ and supernatant was removed by pipetting. Beads were resuspended in $200 \mu \mathrm{L}$ of Native Binding Buffer (50 mM monobasic sodium phosphate (Fisher), $0.5 \mathrm{M} \mathrm{NaCl}$ (Fisher), $\mathrm{pH} 8.0$ ) and centrifuged for 1 minute at $800 \mathrm{x} \mathrm{g}$. Wash in Native Binding Buffer again.

$50 \mu \mathrm{g}$ of protein lysate was added to beads and brought to $200 \mu \mathrm{L}$ with lysis buffer (0.1\% NP-40 in PBS). Samples were incubated for 1 hour at room temperature with gentle agitation, then centrifuged for 1 minute at $800 \mathrm{x}$ g. Supernatant was carefully moved to a new tube. Beads were washed with $300 \mu$ L Native Wash Buffer (50 mM monobasic sodium phosphate, $0.5 \mathrm{M} \mathrm{NaCl}, 20 \mathrm{mM}$ Imidazole (who), $\mathrm{pH}$ 6.0) and centrifuged for 1 minute at $800 \mathrm{x}$ g. Supernatant was removed and wash was repeated 3 more times. Resin beads were eluted in $50 \mu \mathrm{L}$ Native Elution Buffer (45 mM monobasic sodium phosphate, .45 M NaCl, $250 \mathrm{mM}$ Imidazole, $\mathrm{pH} 8.0$ ) by rocking at room temperature for 30 minutes. Beads were centrifuged for 1 minute at $800 \mathrm{x}$ g. Supernatant 
was removed to a new tube and Roche Protease Inhibitor Cocktail was added. Samples were stored at $-80^{\circ} \mathrm{C}$ until needed. 
Table 3-1: Receptor tyrosine kinases in the nucleus. Functions for receptor tyrosine

kinases that have been detected in the nucleus of normal or tumor cells and tissues. Green indicates roles in transcriptional regulation or signal transduction while yellow indicates only transcriptional regulation roles. Table adapted from Kumar 2014 [8].

\begin{tabular}{|c|c|c|c|}
\hline RTK & Tumor cell types & Normal cell types & Function \\
\hline c-Kit & $\begin{array}{l}\text { Gastrointestinal stromal } \\
\text { tumors, SRCC, extrahepatic } \\
\text { bile duct carcinomas }\end{array}$ & not detected & unknown \\
\hline EGFR & $\begin{array}{l}\text { Breast cancer, lung cancer, } \\
\text { ovarian cancer, esophageal } \\
\text { squamous cell carcinoma, } \\
\text { prostate cancer, head and } \\
\text { neck tumor, gastric cancer, T- } \\
\text { cell lymphoblastoma, } \\
\text { pancreatic cancer, colorectal } \\
\text { carcinoma, bladder } \\
\text { carcinoma, }\end{array}$ & $\begin{array}{l}\text { Keratinocytes, } \\
\text { hepatocytes, thyroid } \\
\text { tissue, placenta, mouse } \\
\text { lung epithelial cells, } \\
\text { umbilical endothelial } \\
\text { cells }\end{array}$ & $\begin{array}{l}\text { transcriptional } \\
\text { regulation, } \\
\text { DNA repair, } \\
\text { DNA } \\
\text { replication, } \\
\text { protein activity } \\
\text { regulation }\end{array}$ \\
\hline ErbB2 & $\begin{array}{l}\text { Breast cancer, prolactinoma, } \\
\text { colon cancer, ovarian cancer }\end{array}$ & $\begin{array}{l}\text { Mouse lung epithelial } \\
\text { cells, umbilical } \\
\text { endothelial cells, rat } \\
\text { Schwann cells }\end{array}$ & $\begin{array}{l}\text { transcriptional } \\
\text { regulation, } \\
\text { DNA repair, } \\
\text { therapeutic } \\
\text { resistance to } \\
\text { TKI }\end{array}$ \\
\hline ErbB3 & $\begin{array}{l}\text { Prostate cancer, non-small } \\
\text { cell lung carcinoma }\end{array}$ & $\begin{array}{l}\text { Mouse lung epithelial } \\
\text { cells, umbilical } \\
\text { endothelial cells, rat } \\
\text { Schwann cells, } \\
\text { mammary epithelial } \\
\text { cells }\end{array}$ & $\begin{array}{l}\text { Transcriptional } \\
\text { regulation }\end{array}$ \\
\hline ErbB4 & Prostate cancer, breast cancer & $\begin{array}{l}\text { Mouse lung epithelial } \\
\text { cells, umbilical } \\
\text { endothelial cells, rat } \\
\text { ventricular myocytes, } \\
\text { embryonic neural } \\
\text { precursor cells, fetal } \\
\text { murine type II epithelial } \\
\text { cells, hippocampal } \\
\text { neurons, breast } \\
\text { epithelium }\end{array}$ & $\begin{array}{l}\text { Transcriptional } \\
\text { regulation, } \\
\text { DNA damage } \\
\text { response }\end{array}$ \\
\hline
\end{tabular}




\begin{tabular}{|c|c|c|c|}
\hline FGFR1 & $\begin{array}{l}\text { Medulloblastoma, } \\
\text { neuroblastoma, breast cancer }\end{array}$ & $\begin{array}{l}3 \mathrm{~T} 3 \text { cells, BAMCs, } \\
\text { neuronal progenitor } \\
\text { cells }\end{array}$ & $\begin{array}{l}\text { Transcriptional } \\
\text { regulation }\end{array}$ \\
\hline FGFR2 & $\begin{array}{l}\text { NSCLC, breast cancer, } \\
\text { endometrial carcinoma }\end{array}$ & $\begin{array}{l}\text { Sertoli cells, } \\
\text { immortalized rat } \\
\text { osteoblastic Py1a cells, } \\
\text { stomach progenitor } \\
\text { cells, mammary gland } \\
\text { terminal end bud cells }\end{array}$ & $\begin{array}{l}\text { Transcriptional } \\
\text { regulation }\end{array}$ \\
\hline FGFR3 & $\begin{array}{l}\text { Breast cancer, prostate } \\
\text { cancer, bladder cancer }\end{array}$ & Choroid plexus & Unknown \\
\hline IGF1R & $\begin{array}{l}\text { Prostate cancer, breast cancer, } \\
\text { soft tissue sarcomas, Ewing } \\
\text { sarcoma, hepatocellular } \\
\text { carcinoma }\end{array}$ & Corneal epithelial cells & $\begin{array}{l}\text { Transcriptional } \\
\text { regulation }\end{array}$ \\
\hline IR & $\begin{array}{l}\text { Liver cancer, colonic tumors, } \\
\text { NSCLC }\end{array}$ & $\begin{array}{l}\text { Hepatocytes, } \\
\text { osteoblast-like cells, } \\
\text { corneal epithelial cells, } \\
\text { adipocytes }\end{array}$ & $\begin{array}{l}\text { Transcriptional } \\
\text { regulation }\end{array}$ \\
\hline Mer & Leukemia & not detected & $\begin{array}{l}\text { Chromatin } \\
\text { bound, } \\
\text { unknown } \\
\text { function }\end{array}$ \\
\hline Met & $\begin{array}{l}\text { Melanoma, uveal melanoma, } \\
\text { NSCLC, SCLC, breast } \\
\text { cancer, colon cancer, } \\
\text { testicular cancer, lymphoma, } \\
\text { OSCC }\end{array}$ & $\begin{array}{l}\text { Liver cells, } \\
\text { melanocytes, colon, } \\
\text { skin, testis, lymph node }\end{array}$ & $\begin{array}{l}\text { Transcriptional } \\
\text { regulation }\end{array}$ \\
\hline Ron & Bladder cancer cells & not detected & $\begin{array}{l}\text { Transcriptional } \\
\text { regulation }\end{array}$ \\
\hline Ryk & not detected & Neural progenitor cells & $\begin{array}{l}\text { Transcriptional } \\
\text { regulation }\end{array}$ \\
\hline TrkA & $\begin{array}{l}\text { Pheochromocytoma, glioma, } \\
\text { melanoma, colorectal } \\
\text { carcinoma }\end{array}$ & $\begin{array}{l}\text { Liver, mouse brain, } \\
\text { blastocysts }\end{array}$ & Unknown \\
\hline VEGFR & $\begin{array}{l}\text { AML, ALL, CML, } \\
\text { lymphoma, NSCLC, breast } \\
\text { cancer, cervical carcinoma, } \\
\text { colon cancer, glioma, ovarian } \\
\text { granulosa cell tumor, myxoid } \\
\text { liposarcoma, HNSCC }\end{array}$ & $\begin{array}{l}\text { HUVEC, HCMEC, } \\
\text { HDMEC, HPEC, } \\
\text { cardiac capillary } \\
\text { endothelial cells, human } \\
\text { thyroid follicular cells, } \\
\text { vascular endothelial } \\
\text { cells, rodent Brunner's } \\
\text { gland epithelial cells }\end{array}$ & $\begin{array}{l}\text { Transcriptional } \\
\text { regulation }\end{array}$ \\
\hline
\end{tabular}



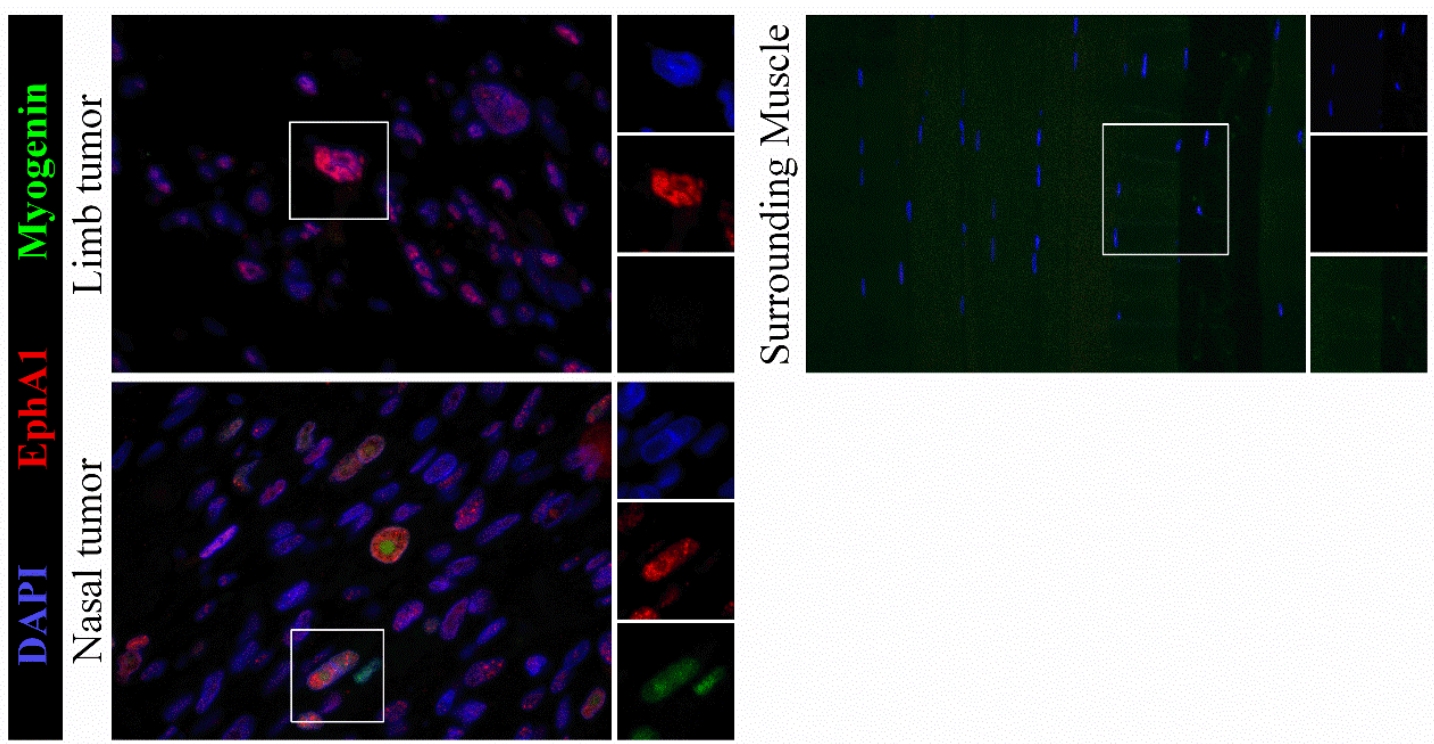

\section{Figure 3-1. EphA1 is expressed in the nucleus of canine RMS tumors}

EphA1 expression was investigated by immunofluorescence in a nasal primary tumor (A) and a limb primary tumor (B) from two different dogs that were formalin fixed and paraffin embedded. After deparaffinization, sections were stained for EphA1 (Alexa 555, red), Myogenin (Alexa 488, green) and nuclei (DAPI, blue). EphA1 was expressed in the nuclei of cells from both tumors, and expression localized to particular regions in the nucleus. The limb tumor was embedded in skeletal muscle, allowing a direct comparison between skeletal muscle tissue and RMS. EphA1 expression was not detected in the nuclei of cells in the surrounding skeletal muscle. 


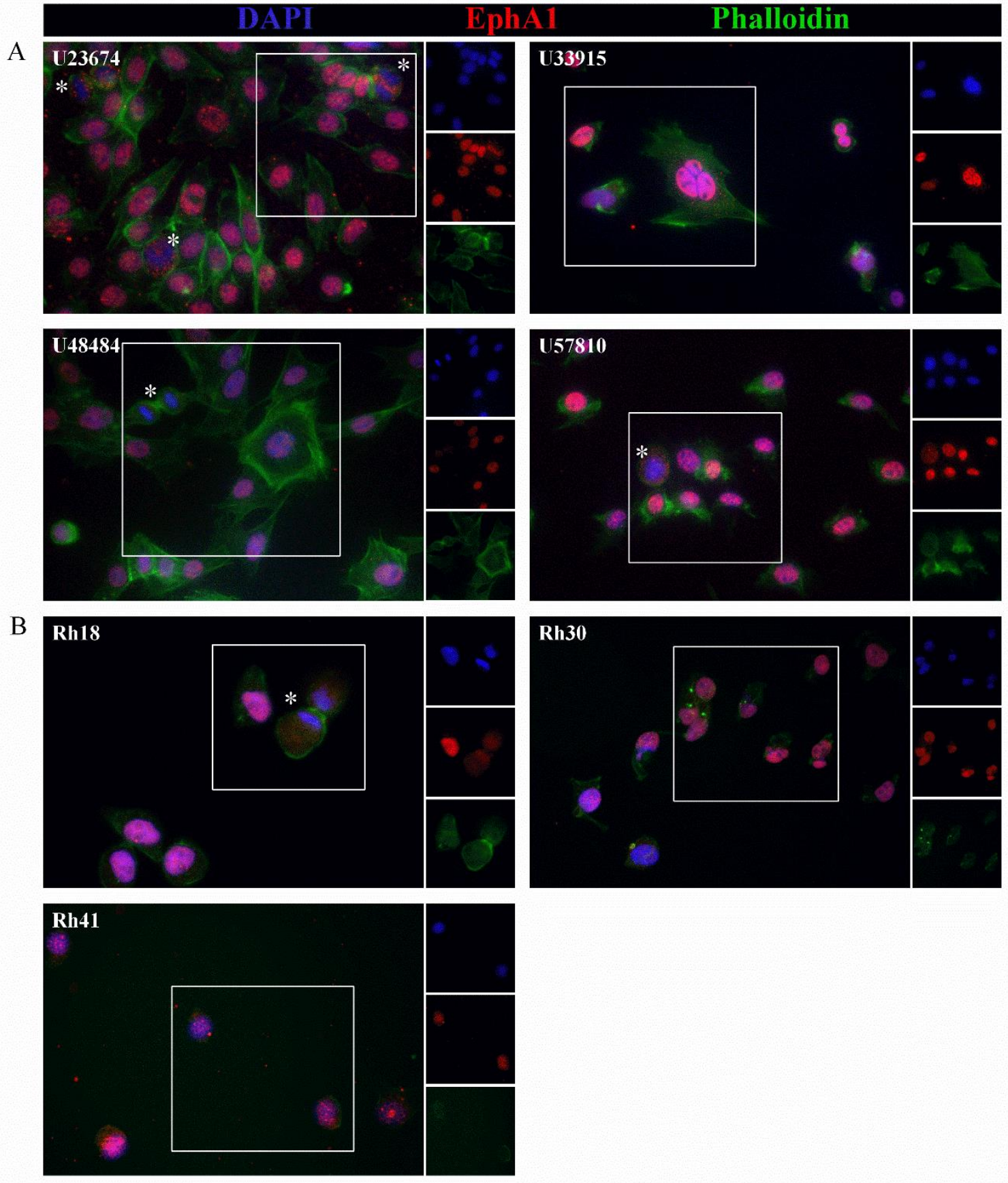

Figure 3-2. EphA1 is in the nucleus of mouse and human RMS cell lines.

Eph and ephrin protein expression was investigated by immunofluorescence in four mouse RMS cell lines (A) U23674 (ARMS), U33915 (ERMS), U48484 (ARMS), U57810 (ERMS) and three human cell lines (B) Rh18 (ERMS), Rh30 (ARMS), Rh41 (ARMS). Cells were grown on glass coverslips coated with gelatin (A) or poly-L-lysine 
(B), fixed in 4\% PFA, and stained for EphA1 (Alexa 555, red), F-actin (phalloidin Alexa 488, green), and nuclei (DAPI, blue). EphA1 was expressed in the nucleus of all mouse and human cell lines except mitotic cells which are marked with an asterisk. EphA1 is still expressed in these cells but is localized diffusely throughout the cell rather than colocalizing with DAPI. 

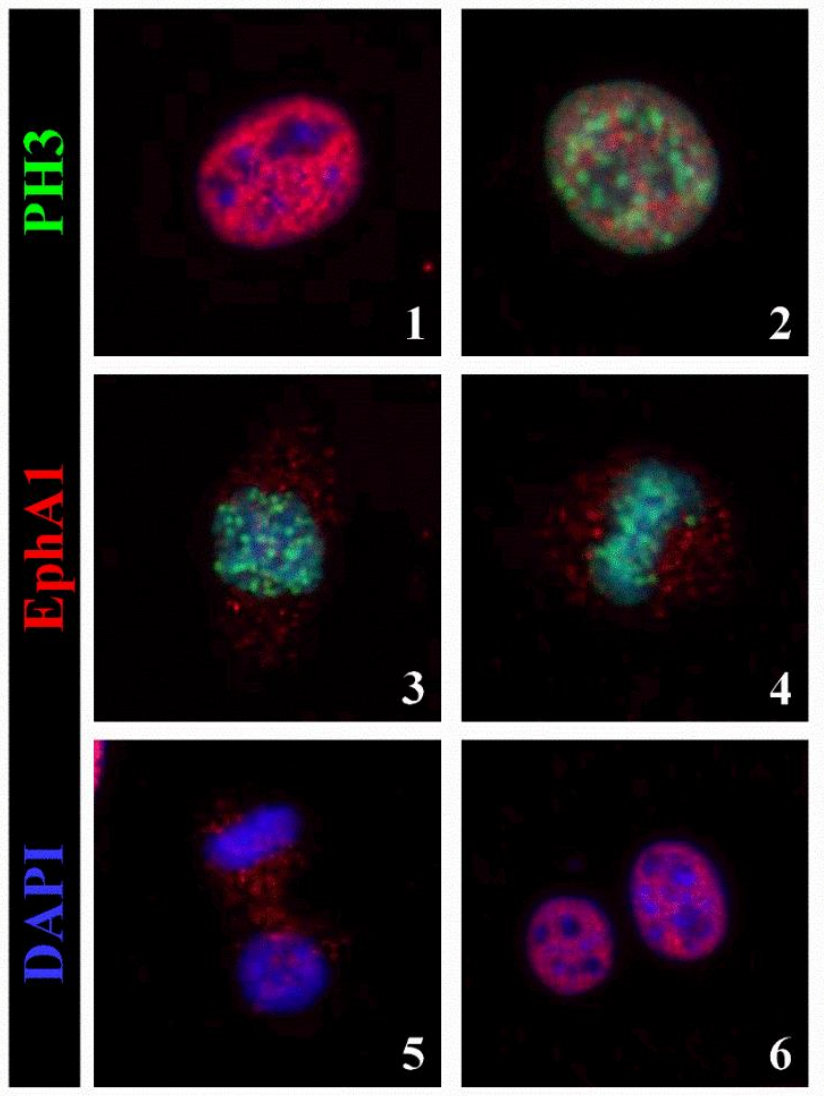

Figure 3-3. EphA1 is differentially localized in distinct phases of the cell cycle Mouse cell line U23674 (ARMS) was plated into glass coverslips coated with gelatin, fixed with 4\% PFA, and stained for EphA1 (Alexa 555, red), PH3 (Alexa 488, green), and nuclei (DAPI, blue) to determine localization of EphA1 throughout the cell cycle. Cells in interphase (1) have nuclear EphA1 expression. At the beginning of the cell cycle in prophase (2), EphA1 is still colocalized with DAPI. Cells in prometaphase (3) no longer have EphA1 and DAPI colocalization. Instead, EphA1 staining is diffuse. This pattern is maintained through metaphase (4) and telophase (5) to be shuttled back into the nucleus after the cell cycle and cytokinesis has completed (6). 


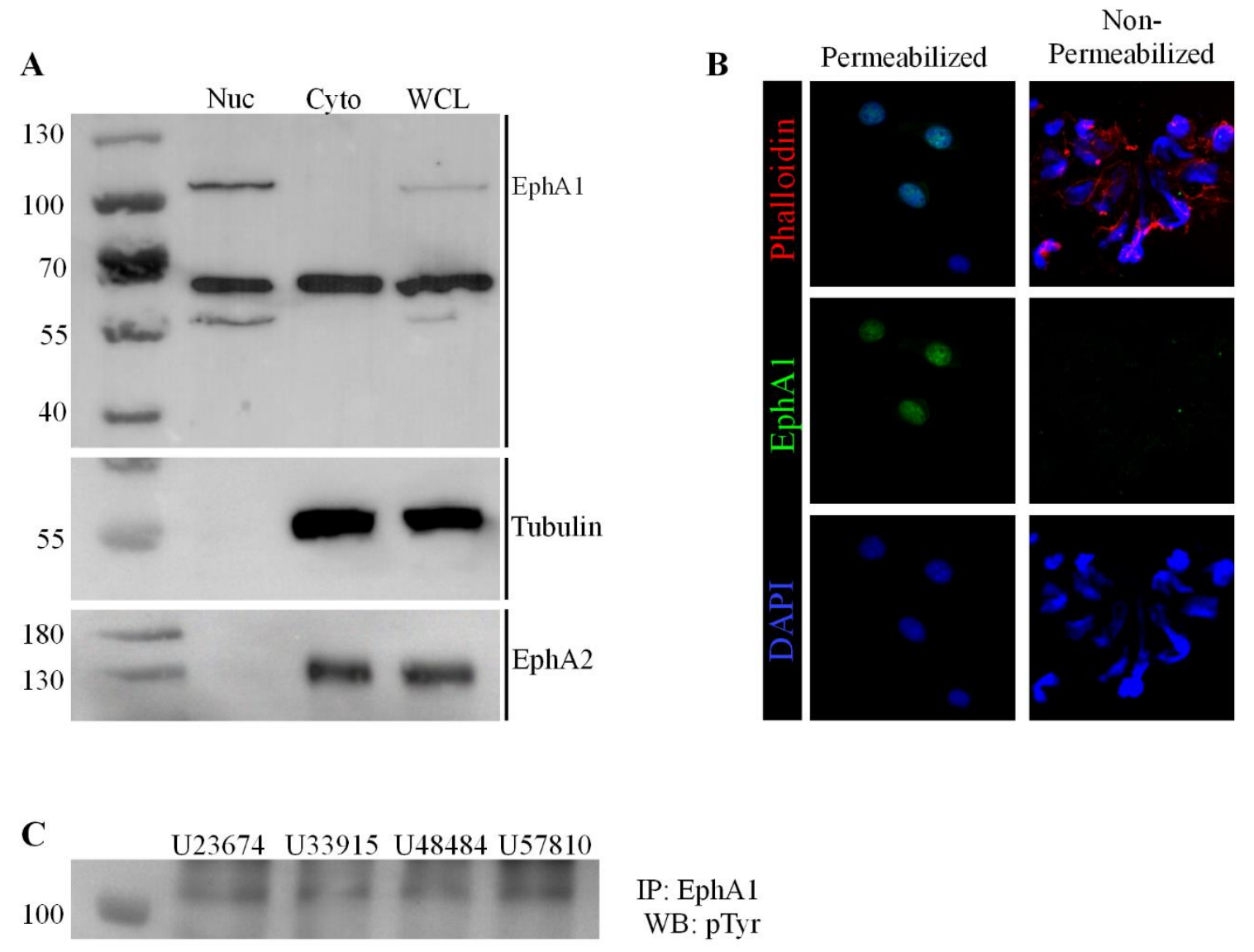

Figure 3-4. EphA1 is in the nucleus of mouse RMS cell lines as a full-length polypeptide that might be phosphorylated

(A) Mouse RMS cell line U23674 was fractionated using a quick-fractionation method. Fractions and whole cell lysates were run on a $10 \%$ polyacrylamide gel and blotted for EphA1, Tubulin, and EphA2. EphA1 has a molecular weight of $108 \mathrm{kDa}$, so the band above the $100 \mathrm{kDa}$ marker indicates EphA1 is in the nucleus as a full-length receptor. Tubulin indicates that the nuclear fraction is not contaminated with cytoplasmic proteins, and EphA2 indicates that the nuclear fraction is not contaminated with membrane proteins. The band at $65 \mathrm{kDa}$ is an artifact of using an antibody raised in rabbits. (B) Mouse RMS cell line U23674 was grown on glass coverslips with gelatin. Permeabilized cells were fixed in 4\% PFA and stained for EphA1 with an antibody 
towards the N-terminal, extracellular domain (Alexa 488, green) using 1\% NP40.

Unpermeablized cells were stained with the same antibody targeting the N-terminal domain of EphA1 but without detergent, allowing for detection of only EphA1 on the surface. (C) Whole cell lysates were collected from all four mouse cell lines, immunoprecipitation was performed with an anti-phosphotyrosine antibody, and then Western blotting was performed with an anti-EphA1 antibody. A band just above the 100 $\mathrm{kDa}$ marker indicates that full-length EphA1 is likely phosphorylated in all four mouse RMS cell lines. 

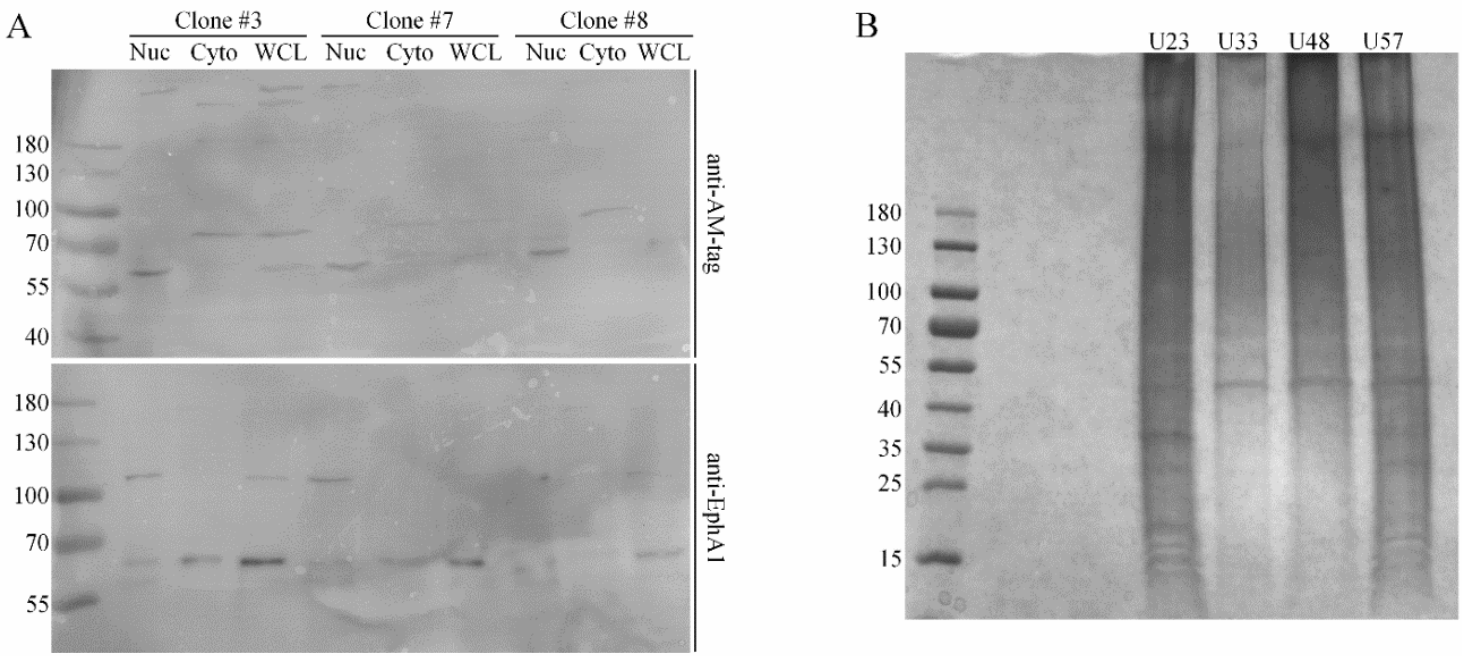

\section{Figure 3-5. Isolating EphA1 from mouse RMS cell lysates.}

(A) Mouse ARMS cell line U48484 was transfected with the pAM_1C vector with EphA1 inserted, creating an AM-tagged EphA1 fusion protein. Stable cell lines were generated clonaly using puromycin selection until individual colonies were picked and numbered. Stable cell lines were expanded in cell culture and then harvested for subcellular fractionation. Fractions were run simultaneously on two polyacrylamide gels and western blotting was performed with an anti-AM-tag antibody (Active Motif) or an anti-EphA1 antibody (Santa Cruz). EphA1-AM is expected to be around $108 \mathrm{kDa}$. Blotting with anti-AM resulted in an abundance of non-specific bands and nothing corresponding to the $108 \mathrm{kDa}$ expected band. Blotting with anti-EphA1 indicates that EphA1 antibody was detected in the nuclear fraction and whole cell lysate of these samples. (B) Silver staining was used to detect proteins in samples after immunoprecipitation with anti-EphA1 (Santa Cruz) from nuclear fractions of all four mouse RMS cell lines - U23374 (U23), U33915 (U33), U48484 (U48), and U57810 (U57). Presence of distinct bands indicates protein in immunoprecipitated samples from all four cell lines. 
A

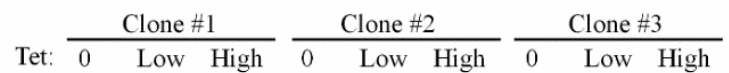

180

130

100

$$
70
$$

Nickel Resin Pulldown from Nuclear Fractions

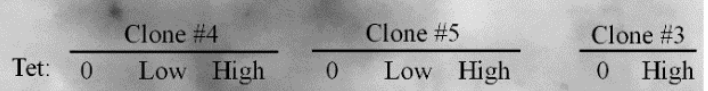

180

130

100

70

Nickel Resin Pulldown from Nuclear Fractions

Whole Cell
B

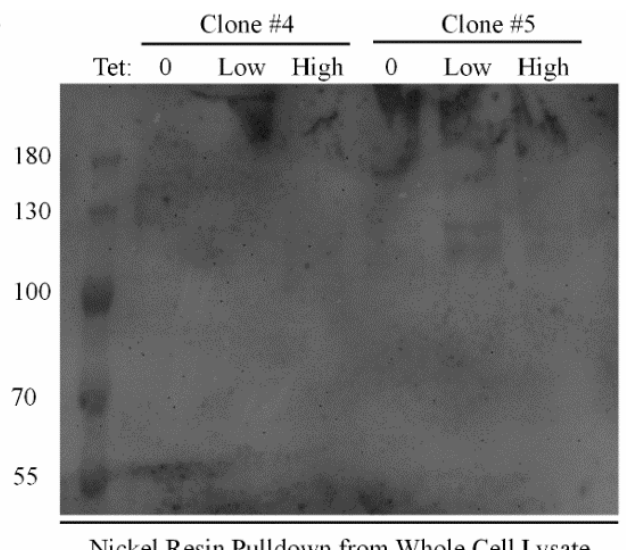

Nickel Resin Pulldown from Whole Cell Lysate

Figure 3-6. Inducing expression of EphA1-myc-His.

Mouse ERMS cell line U33915 was co-transfected with pcDNA6/TR and pcDNA4/TO/EphA1-myc-His. Stable cell lines were generated clonaly by selection with blasticidin and zeocin. Individual colonies were picked and expanded in culture. After a 24-hour incubation with a low-dose $(0.5 \mu \mathrm{g} / \mathrm{mL})$ or high-dose $(1 \mu \mathrm{g} / \mathrm{ml})$ of tetracycline, cells were harvested for subcellular fractionation. EphA1-myc-His was isolated from nuclear fractions (A) and whole cell lysate (B) using ProBond Nickel-Chelating Resin beads. Presence of EphA1-myc-His, expected around $110 \mathrm{kDa}$, was detected by western blotting with anti-EphA1. 


\section{$\underline{\text { Literature Cited }}$}

1. Gurney, J.G., et al., Soft Tissue Sarcomas, in Cancer Incidence and Survival among Children and Adolescents: United States SEER Program 1975-1995, L. Ries, et al., Editors. 1999, NIH Pub: Bethesda, MD. p. 111-123.

2. Ognjanovic, S., et al., Trends in childhood rhabdomyosarcoma incidence and survival in the United States, 1975-2005. Cancer, 2009. 115(18): p. 4218-26.

3. Perez, E.A., et al., Rhabdomyosarcoma in children: a SEER population based study. J Surg Res, 2011. 170(2): p. e243-51.

4. Davicioni, E., et al., Gene expression profiling for survival prediction in pediatric rhabdomyosarcomas: a report from the children's oncology group. J Clin Oncol, 2010. 28(7): p. 1240-6.

5. Sorkin, A. and M. Von Zastrow, Signal transduction and endocytosis: close encounters of many kinds. Nat Rev Mol Cell Biol, 2002. 3(8): p. 600-14.

6. Lin, S.-Y., et al., Nuclear localization of EGF receptor and its potential new role as a transcription factor. Nature Cell Biology, 2001. 3: p. 802-808.

7. $\quad \mathrm{Ni}, \mathrm{C} .-\mathrm{Y}$., et al., $\gamma$-Secretase Cleavage and Nuclear Localization of Erb-B4 Receptor Tyrosine Kinase. Science, 2001. 294: p. 2179-2181.

8. Kumar, R., Nuclear Signaling Pathways and Targeting Transcription in Cancer. Cancer Drug Discovery and Development, ed. B.A. Teicher. 2014: Humana Press.

9. Stephenson, S.-A., I. Mertens-Walker, and A. Herington, Signaling of Receptor Tyrosine Kinases in the Nucleus, in Current Frontiers and Perspectives in Cell Biology, S. Najman, Editor. 2012, InTech. p. 211-234.

10. Robinson, D.R., Y.-M. Wu, and S.-F. Lin, The protein tyrosine kinase family of the human genome. Oncogene, 2000. 19: p. 5548.

11. Lo, H.-W., et al., Novel Prognostic Value of Nuclear Epidermal Growth Factor Receptor in Breast Cancer. Cancer Res, 2005. 65(1): p. 338-348.

12. Wang, S.C. and M.C. Hung, Nuclear translocation of the epidermal growth factor receptor family membrane tyrosine kinase receptors. Clin Cancer Res, 2009. 15(21): p. 6484-9.

13. Muraoka-Cook, R.S., et al., ErbB4/HER4: role in mammary gland development, differentiation and growth inhibition. J Mammary Gland Biol Neoplasia, 2008. 13(2): p. 235-46.

14. Carpenter, G. and H.J. Liao, Trafficking of receptor tyrosine kinases to the nucleus. Exp Cell Res, 2009. 315(9): p. 1556-66.

15. Kuroda, C., et al., Distribution, gene expression, and functional role of EphA4 during ossification. Biochem Biophys Res Commun, 2008. 374(1): p. 22-7.

16. Staquicini, F.I., et al., Receptor tyrosine kinase EphA5 is a functional molecular target in human lung cancer. J Biol Chem, 2015. 290(12): p. 7345-59.

17. Mertens-Walker, I., et al., EphB4 localises to the nucleus of prostate cancer cells. Exp Cell Res, 2015. 333(1): p. 105-15.

18. Sebire, N. and M. Malone, Myogenin and MyoD1 expression in paediatric rhabdomyosarcomas. Journal of Clinical Pathology, 2003. 56: p. 412-416.

19. Jiang, G., et al., Histone modification in constitutive heterochromatin versus unexpressed euchromatin in human cells. J Cell Biochem, 2004. 93(2): p. 286300. 
20. Cessna, M.H., et al., Are Myogenin and MyoD1 Expression Specific for Rhabdomyosarcoma? A Study of 150 Cases, With Emphasis on Spindle Cell Mimics. The American Journal of Surgical Pathology. 25(9): p. 1150-1157.

21. Houghton, J.A., P.J. Houghton, and B.L. Webber, Growth and characterization of childhood rhabdomyosarcoma as xenograftsJournal of the National Cancer Institute, 1982.

22. Hinson, A.R., et al., Human rhabdomyosarcoma cell lines for rhabdomyosarcoma research: utility and pitfalls. Front Oncol, 2013. 3: p. 183.

23. Douglass, E.C., et al., A specific chromosomal abnormality in rhabdomyosarcoma. Cytogenet Cell Genet, 1987. 45(3-4): p. 148-55.

24. Keller, C. and M.R. Capecchi, New genetic tactics to model alveolar rhabdomyosarcoma in the mouse. Cancer Res, 2005. 65(17): p. 7530-2.

25. Rubin, B.P., et al., Evidence for an unanticipated relationship between undifferentiated pleomorphic sarcoma and embryonal rhabdomyosarcoma. Cancer Cell, 2011. 19(2): p. 177-91.

26. Sauvé, D.M., et al., Phosphorylation-induced Rearrangement of the Histone H3 NH2-terminal Domain during Mitotic Chromosome Condensation. The Journal of Cell Biology, 1999. 145(2): p. 225-235.

27. Hynes, N.E. and H.A. Lane, ERBB receptors and cancer: the complexity of targeted inhibitors. Nat Rev Cancer, 2005. 5(5): p. 341-54.

28. Jones, F.E., HER4 intracellular domain (4ICD) activity in the developing mammary gland and breast cancer. J Mammary Gland Biol Neoplasia, 2008. 13(2): p. 247-58.

29. Lange, A., et al., Classical nuclear localization signals: definition, function, and interaction with importin alpha. J Biol Chem, 2007. 282(8): p. 5101-5.

30. Stark, D.A., et al., Eph/ephrin interactions modulate muscle satellite cell motility and patterning. Development, 2011. 138(24): p. 5279-89.

31. Wang, Y.N., et al., The translocon Sec61beta localized in the inner nuclear membrane transports membrane-embedded EGF receptor to the nucleus. J Biol Chem, 2010. 285(49): p. 38720-9.

32. Silhavy, T.J., S.A. Benson, and S.D. Emr, Mechanisms of protein localization. Microbiological reviews, 1983. 47(3): p. 313-344.

33. Suzuki, K., et al., REAP: A two minute cell fractionation method. BMC Res Notes, 2010. 3: p. 294. 


\section{Chapter 4:}

\section{EphA7 and Syndecan-4 Involvement in Rhabdomyosarcoma}

Ronnie LaCombe ${ }^{1}$, Alessandra Cecchini ${ }^{1}$, Sydney Loethen ${ }^{1}$, and DDW Cornelison ${ }^{1,2}$

\footnotetext{
${ }^{1}$ Division of Biological Sciences and Bond Life Sciences Center, University of Missouri, Columbia, MO

2 to whom correspondence should be addressed
} 


\section{Abstract}

Rhabdomyosarcoma (RMS) treatment options have remained unchanged for nearly 30 years and is limited to chemotherapy, surgery, and radiation therapy.

Development of a targeted therapy is of high importance to improve patient outcome. Our group has recently identified EphA7 as a contact-mediated promoter of myoblast differentiation. Here we test the viability of EphA7 for use as a differentiation therapy option for RMS treatment. Results are still preliminary but indicate that treatment with EphA7 might slow proliferation rates of RMS cell lines. Syndecan-4 is expressed by satellite cells and plays key roles in regeneration and differentiation of skeletal muscle after injury. All four mouse RMS cell line express syndecan-4, and its expression is detected in the nucleus after treatment to disrupt lipid rafts and therefore syndecan-4 signaling. Nuclear syndecan-4 has previously been identified as an important regulator in differentiation of myogenic cells. These preliminary data suggest that experiments that extended treatment with lipid-raft disrupting agents could affect RMS proliferation rates and differentiation status. 


\section{$\underline{\text { Introduction }}$}

\section{EphA7 signaling in stem cells and cancer}

EphA7 receptor tyrosine kinase is unique in the Eph family in that it has several isoforms. In addition to the full-length receptor, there are two splice variants that encoded for truncate polypeptides that lack the kinase domain, effectively removing forward signaling capabilities of these variants [1]. One of the truncated versions retains its transmembrane domain and when expressed in the same cell as full-length EphA7 acts as a dominant-negative inhibitor. Full-length EphA7 cannot activate forward signaling when dimerize with the truncated isoform due to lack of a kinase domain to transautophosphorylate and activate it [1]. The second truncated isoform of EphA7 is missing the transmembrane domain as well as the kinase domain, which results in its secretion from cells [2]. Secreted, truncated EphA7 is able to activate reverse ephrin signaling on non-adjacent cells, which is atypical for Eph-ephrin signaling [3].

EphA7 regulates a variety of cellular functions such as cell motility, cell adhesion and repulsion, and proliferation in adult and developing tissues as well as stem cells. EphA7 signaling can have negative effects on proliferation rates and stem cell properties of progenitor cells [4]. In the subventricular zone, EphA7 expression on ependymal cells and astrocytes negatively regulates proliferation of neuroblasts through ephrinA2 reverse signaling [5]. EphA7 also initiates reverse signaling in stem cells of hair follicles leading to decreased rates of proliferation [6]. Intriguingly, the secreted, truncated isoform of EphA7 actually promotes the reprogramming of differentiated satellite cells: stimulation with truncated EphA7 reduces ERK1/2 activity, a crucial step in generation of induced pluripotent stem cells [2]. 
EphA7 expression is downregulated in many cancers including glioblastoma, leukemia, and prostate cancer [7-10]. Expression levels of EphA7 are correlated with metastasis in esophageal squamous cell carcinoma; patients with high levels of EphA7 expression were significantly less likely to have lymph node metastases than patients with low levels of EphA7 expression [9]. EphA7 expression is downregulated in prostate and colorectal cancers by methylation and occurs more frequently in advanced tumors, suggesting that loss of EphA7 promotes cancer progression [7, 8, 11]. Knockdown of truncated EphA7 in lymphoma accelerated tumor development and subsequent reexpression caused tumor regression [3]. Exogenous application of truncated EphA7 by local injection or systemic distribution halted tumor cell growth and even induced apoptosis in cancer cells, indicating that it could have therapeutic potential [3].

\section{Syndecan-4 expression in satellite cells}

Syndecan-4 is a type-I transmembrane protein with an extracellular domain that is modified with heparan sulfate and chondroitin sulfate side chains [12]. These side chains are necessary for syndecan-4 with the ability to act as a co-receptor for RTKs and adhesion receptors and thus affect proliferation, differentiation, adhesion, and migration in multiple cell types [13-16]. Syndecan-4 alters proliferation rates and differentiation through interaction with growth factor receptors such as FGF2 [15, 17]. Syndecan-4 effects on adhesion and migration are often mediated through interaction and activation of Protein Kinase C [13, 14, 16].

Syndecan-4 is a lineage marker for satellite cells in adult muscle [18]. It also necessary satellite cell and skeletal muscle function. Syndecan-4 null satellite cells have defects in activation, proliferation, and differentiation [19]. Syndecan-4 null satellite cells 
also have migration defects. This leads to significant impairment of skeletal muscle's ability to quickly regenerate after injury [19]. Because of its role in proliferation and differentiation and critical functions in satellite cells, syndecan-4 expression in RMS cells could indicate that it developed from a myogenic cell such as a satellite cell.

\section{$\underline{\text { Results }}$}

\section{EphA7 reduces cell growth rates of RMS cells}

Recent studies in our lab from Laura Arnold and Alessandra Cecchini identified a cell non-autonomous effect of EphA7 in promoting differentiation of myoblasts. This result as well as use of exogenous EphA7 to halt tumor growth in other cell lines led us to investigate how mouse RMS cell lines would respond to EphA7 treatment. To do this, we seeded ARMS cell line U23674 onto laminin-coated coverslips with or without immobilized EphA7-Fc chimeric protein. Bromodeoxyuridine (BrdU), an analog of thymidine that is incorporated during DNA synthesis, was added to the cells in four sequential, 12-hour increments to capture proliferation rates over 48 hours of EphA7 treatment. Immunofluorescence was used to visual BrdU-positive cells and were counted.

After 12 hours of exposure to EphA7-Fc, there was no difference between treated or untreated cells (Figure 4-1A and B). Proliferation rates appeared to decrease from 12 to 24 hours, as $83 \%$ of control cells and $40 \%$ of EphA7-treated cells were BrdU-positive (Figure 4-1B). BrdU incorporation and proliferation rates increased 24 to 36 hours, but there was no difference between treated and untreated cells (Figure 4-1A). In the last window from 36 to 48 hours we saw a dramatic difference in the total number of cells and the percentage of BrdU positive cells between treated and untreated samples. There 
were half as many EphA7-treated cells as there were untreated, control cells (Figure 41A). There were also fewer BrdU positive EphA7-treated cells as there were control cells, 69\% and 95\% respectively (Figure 4-1B). The difference in total cell numbers as well as proportion of BrdU cells is readily apparent in images (Figure 4-1C). This suggests that EphA7-Fc treatment reduces proliferation rates of mouse RMS cells.

\section{EphA7 treatment does not shift cell cycle distribution of RMS cells}

To verify effects of EphA7-Fc on proliferation rates of RMS cells, we looked for shifts in the distribution of cells in cell cycle. U23674 ARMS cells were grown in gelatincoated 6-well tissue culture dishes with or without EphA7-Fc immobilized to the bottom of the wells for 24 hours, 48 hours, or 96 hours then fixed in ethanol and stained with propidium iodide (PI). PI is a fluorescent intercalating agent that binds to DNA and can be detected through Fluorescent-Activated Cell Sorting (FACS) [20]. Total DNA content is detected and used to assign cells to the cell cycle phases $G_{1}, S$, and $G_{2}$, as cells in $G_{2}$ contain twice as much DNA as cells in $\mathrm{G}_{1}$ after replication in the $S$ phase [20,21]. If there is a shift towards more cells in $\mathrm{G}_{1}$ after treatment then EphA7 could be acting to slow proliferation by preventing progression through the cell cycle. While there were slightly more treated cells in $\mathrm{G}_{1}$ at 24 and 96 hours, there were no significant differences between cell cycle distribution of treated and untreated cells (Figure 4-2). FACS analysis detected a population of cells from these samples that contained more DNA than expected for cells in $\mathrm{G}_{2}$, which we determined were likely to be multinucleated cells. A small portion of mouse RMS cells are multinucleated (Figure 3-2) but increasing levels of cells in this population (referred to as $4 n+$ ) could indicate that cells are fusing to 
become multinucleate, a process that happens during myogenic differentiation. We had two samples for the 96-hour time point - one seeded at the same density and one seeded at $25 \%$ of the density of the other time points. There were more $4 n+$ EphA7-treated cells when seeded at $25 \%$ density (Figure $4-2$ ). This suggests that density of the cells might affect ARMS cell response to EphA7-Fc treatment and should be considered in future experiments.

\section{All four mouse RMS cell lines express satellite cell marker syndecan-4}

As RMS expressed muscle specific genes, the satellite cell is a proposed cell of origin. However, expression of muscle specific genes could be aberrantly expressed in a non-myogenic cell of origin. Syndecan-4 is a marker for satellite cells, so expression in RMS could provide support for the satellite cell-of-origin hypothesis. We used fluorescent immunostaining to test for expression of syndecan-4 in RMS. All four cell lines expressed syndecan-4 (Figure 4-3). Syndecan-4 was detected in distinct, punctate regions which is typical for transmembrane proteins restricted to membrane lipid rafts. If no longer confined to lipid rafts, then downstream signaling through syndecan-4 will be disrupted. ARMS cell line U23674 was grown on gelatin-coated coverslips and treated with methyl- $\beta$-cyclodextrin $(\mathrm{M} \beta \mathrm{CD}$ ) for 24 hours. Immunofluorescence was used to detected Syndecan-4 localization. A shift from a punctate expression pattern to a diffuse expression pattern would indicate that lipid rafts have been successfully disrupted. Syndecan-4 expression in cells treated with $\mathrm{M} \beta \mathrm{CD}$ did appear to change, but in an unexpected way. There appears to be an accumulation of syndecan-4 in the nucleus after $\mathrm{M} \beta C D$ treatment (Figure 4-4). These data demonstrate that syndecan-4 is expressed by 
mouse RMS cell lines in a way that is not specific to RMS subtypes, lending support to the hypothesis that satellite cells are the RMS cell-of-origin.

\section{$\underline{\text { Discussion }}$}

EphA7 is an RTK that has a well described role in negatively regulating proliferation rates while promoting differentiation via reverse signaling. This combination of functions is unfavorable for tumorigenesis, so it is unsurprising that EphA7 is downregulated in a variety of tumors $[7-9,11]$. Low expression of EphA7 leads to higher rates of metastasis in esophageal squamous cell carcinoma and increased rates of tumor formation and progression in lymphoma [3, 9]. Exposing tumors to EphA7 was able to halt tumor growth and even promote apoptosis, highlighting its potential as a therapeutic intervention strategy [3].

Our lab has recently identified EphA7 as a mediator of myoblast differentiation via a cell non-autonomous mechanism. This in combination with its tumor suppressor properties led us to test the effect of EphA7 exposure on RMS cells. Proliferation rate over a 48-hour period were analyzed by comparing incorporation of BrdU. Only cells that divided during the 12-hour period of BrdU exposure will incorporate it into their DNA, so a direct comparison can be made between treated and untreated cells. Initial results from U23674 ARMS cells were promising, as there was half as many EphA7-treated cells at the final time point as there were untreated cells (Figure 4-1A), suggesting that EphA7 treatment might negatively regulate proliferation rates of U23674 cells. Cell cycle analysis did not demonstrate the same effect, however. There were no differences in distribution of treated or untreated cells at any timepoints (Figure 4-2). 
This difference in results could be explained in a few ways. First, the three trials were not all run simultaneously. Results would be more reliable if triplicate samples were seeded and collected at the same time. Second, cells were seeded on laminin-coated glass coverslips for the BrdU experiment but on gelatin-coated 6-well plastic tissue culture dishes for cell cycle analysis. It is possible that substrate differences could have affected results. This experiment should be repeated to see if results are the same. It would also be interesting to test U48484 on EphA7-Fc as it grows faster than the other cell lines. Alterations to growth rate might be more readily detectable in this cell line.

Syndecan-4 is a transmembrane protein that interacts with other transmembrane proteins to alter proliferation, differentiation, adhesion and migration [22]. It is also expressed by satellite cells and is critical to satellite cell mediated muscle regeneration after injury [19]. We found that all four mouse RMS cell lines express syndecan-4, which lends support to the satellite cell RMS cell-of-origin theory (Figure 4-3). syndecan-4 signaling is dependent upon localization to lipid rafts [23]. Treatment with $\mathrm{M} \beta \mathrm{CD}$ disrupts lipid rafts, halting signaling downstream of Syndecan-4. ARMS cell line U23674 was treated with $\mathrm{M} \beta \mathrm{CD}$ for 24-hours. Immunofluorescence staining identified that syndecan-4 localization was altered in response to $\mathrm{M} \beta \mathrm{CD}$, but expression was not diffuse across the membrane as expected (Figure 4-4.) Instead, $\mathrm{M} \beta \mathrm{CD}$ appeared to induce nuclear localization of syndecan-4. While this observation was unexpected, a search through the literature identified nuclear localization of syndecan-4 as an important regulator of myogenesis by affecting differentiation of muscle cells [24]. It would be intriguing to extend the time-course of $\mathrm{M} \beta \mathrm{CD}$ to see how long-term attenuation of syndecan-4 signaling would affect RMS cells. 


\section{Materials and Methods}

\section{Cell culture and samples}

Mouse rhabdomyosarcoma cell lines were graciously provided by Dr. Charles

Keller. These cell lines were generated from tumors in transgenic mice with the following mutations to cause RMS: U23674 (Myf6Cre/Pax3-Foxo1/p53-/-), U33915 (Pax7CreER, Ptch1, p53 ${ }^{-/-}$), U48484 (Myf6Cre/Pax3-Foxo1/p53 ${ }^{-/-}$), U57810 (Myf6Cre/p53 ${ }^{-/}$). Mouse RMS cell lines are cultured in DMEM (Gibco) with 10\% Fetal Bovine Serum (Sigma) and $1 \%$ Anti-Anti (Gibco) at $37{ }^{\circ} \mathrm{C}$ and $5 \% \mathrm{CO}_{2}$ in a humidified incubator (Heracell 150 , Heraeus).

\section{BrdU time course on RMS cells}

Glass coverslips (Corning) were acid washed and coated with laminin 111 (Sigma) by incubation at $37^{\circ} \mathrm{C}$ for 3 hours in a humidified incubator (Heracell 150). Coverslips were then washed twice in DPBS and incubated with $5 \mu \mathrm{g} / \mathrm{mL}$ EphA7-Fc (R\&D) in DPBS or DPBS as a control for 1 hour at $37^{\circ} \mathrm{C}$ in the incubator. Solution was carefully removed, and coverslips were immersed in culture medium until use. U23674 cells were seeded into coverslips at a density of 25 cells $/ \mathrm{mm}^{2}$. BrdU (Invitrogen) was added to separate wells for a $10 \mu \mathrm{M}$ final concentration at 0 hours, 12 hours, 24 hours, and 36 hours. 12 hours after addition of BrdU cells washed in cold DPBS and fixed to coverslips with $4 \%$ paraformaldehyde (PFA) for 10 minutes at $4^{\circ} \mathrm{C}$. Coverslips were washed once in cold PBS and then stored in PBS at $4^{\circ} \mathrm{C}$ until use.

To stain for BrdU, fixed coverslips were incubated for 10 minutes in $1 \mathrm{M} \mathrm{HCl}$ (Fisher) at room temperature then washed three times in PBS. Then coverslips were blocked for 1 hour in 10\% normal goat serum (Sigma) with 0.2\% TritonX-100 (Fisher). 
Anti-BrdU (Abcam) was diluted 1:200 in 10\% NGS with 0.2\% TritonX-100 and incubated overnight at $4^{\circ} \mathrm{C}$. Cells were washed for 5 minutes in PBS three times then anti-goat 555 (Santa Cruz) was diluted 1:500 in 10\% NGS with 0.2\% TritonX-100 and incubated with coverslips for 1 hour at room temperature. Coverslips were mounted in VectaShield with DAPI (Vector Labs). Images were acquired and processed on an Olympus BX61 upright microscope using Slidebook software (Intelligent Imagine Innovations). ImageJ software was used to subtract background and count nuclei and BrdU-positive cells in a field of view. 7 fields of view were counted for each time point and averaged. Calculations and graphs were done Microsoft Excel.

\section{Cell Cycle Analysis by Propidium Iodide Staining}

6-well tissue culture plates were coated with 6.6\% gelatin (USB) then incubated overnight at $4^{\circ} \mathrm{C}$ with $5 \mu \mathrm{g} / \mathrm{mL}$ EphA7-Fc. $1.5 \mathrm{~mL}$ microcentrifuge tubes (USA Scientific) were blocked with $2 \%$ BSA (Fisher) in DPBS overnight at $4{ }^{\circ} \mathrm{C}$ with agitation. EphA7-Fc solution was removed and wells were blocked in 2\% BSA for at least 1 hour at room temperature. BSA was removed and cells were seeded at $25 \mathrm{cells} / \mathrm{mm}^{2}$ except for the 96 -hour $25 \%$ density sample seeded at 6.25 cells $/ \mathrm{mm}^{2}$ in culture media and cultured in a $37^{\circ} \mathrm{C}$ humidified incubator (Heracell 150). Cells were harvested by incubation with trypsin (Corning) at 0 hours, 24 hours, 48 hours, and 96 hours and collected into blocked $1.5 \mathrm{~mL}$ microcentrifuge tubes. Cells were gently centrifuged at $200 \mathrm{x}$ g at room temperature for 5 minutes. Supernatant was aspirated and resuspended in $300 \mu \mathrm{L}$ cold DPBS (Fisher), pipetting up and down 20 times to ensure complete resuspension. $2 \mu \mathrm{L}$ of $2 \% \mathrm{BSA}$ and $700 \mu \mathrm{L}$ of ice cold $100 \%$ ethanol (Fisher) was added and resuspended 5 times and incubated overnight at $-20^{\circ} \mathrm{C}$. 
After all time points were fixed, cells were centrifuged at $200 \mathrm{x}$ g for 10 minutes at $4^{\circ} \mathrm{C}$. Cell pellets were washed in cold PBS before centrifuging again. Cells were resuspended in $300 \mu \mathrm{L}$ propidium iodide staining solution (10 mL PBS, $100 \mu \mathrm{L}$ TritonX100 (Fisher), $100 \mu \mathrm{L} 2 \mathrm{mg} / \mathrm{mL}$ RNaseA (Roche), $200 \mu \mathrm{L} 1 \mathrm{mg} / \mathrm{mL}$ propidium iodide (MP Biomedicals) and incubated for 15 minutes at $37^{\circ} \mathrm{C}$. Samples were protected from light and incubated in fridge overnight at $-20^{\circ} \mathrm{C}$. FACS data was collected using a BDAccuri C6 Flow Cytometer (BD Biosciences) and processed with FlowJo

\section{(https://www.flowjo.com/).}

\section{Methyl-p-cyclodextrin treatment}

U23674 cells were seeded onto glass coverslips coated with $6.6 \%$ gelatin and grown to $70 \%$ confluency. Culture media was replaced with culture media containing $2 \%$ methyl- $\beta$-cyclodextrin (Sigma). 24 hours later coverslips were washed twice in cold DPBS and fixed in 4\% PFA on ice for 10 minutes. Coverslips were then stored in PBS at $4^{\circ} \mathrm{C}$ until ready for use.

\section{Immunofluorescence for syndecan-4}

Fixed cells on glass coverslips were blocked 20\% BlokHen (Aves Labs) for 1 hour at room temperature. Chicken anti-syndecan4 (Cornelison et al 2004) was diluted 1:1500 in 10\% normal goat serum with 1\% Nonidet-P40 (USB Corporation) and incubated with coverslips overnight at $4^{\circ} \mathrm{C}$, washed, incubated with anti-chicken 555 secondary antibody (Santa Cruz) for 1 hour at room temperature, and washed again. Cells were then stained with Alexa 488-labeled phalloidin (Invitrogen) diluted 1:20 from a stock solution of $6.6 \mu \mathrm{M}$ into PBS and incubated at room temperature for 30 minutes. Cells were then washed and mounted in Vectashield containing DAPI (Vector Labs). All 
images were acquired and processed on an Olympus BX61 upright microscope using Slidebook software (Intelligent Imagine Innovations) or $\mu$ Manager software (www.micro-manager.org). Digital background subtraction was performed to remove signal that was less than or equal to levels present in control samples (processed with primary antibody) and was applied equally to the entire field. 
A

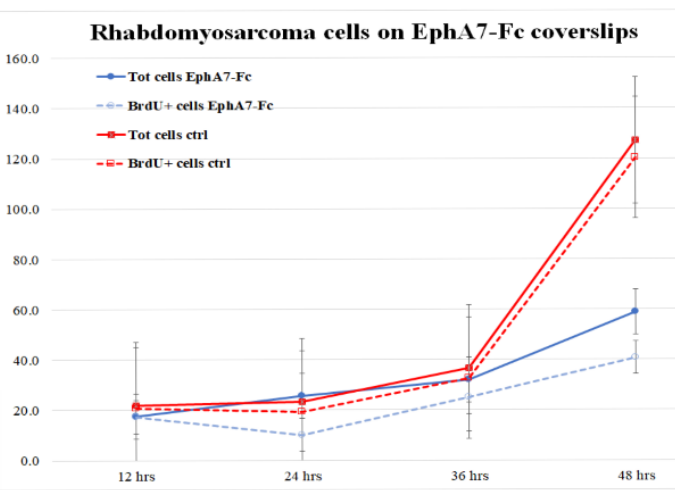

C

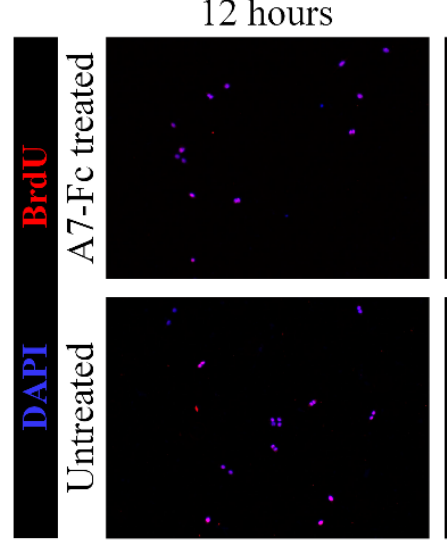

24 hours
B
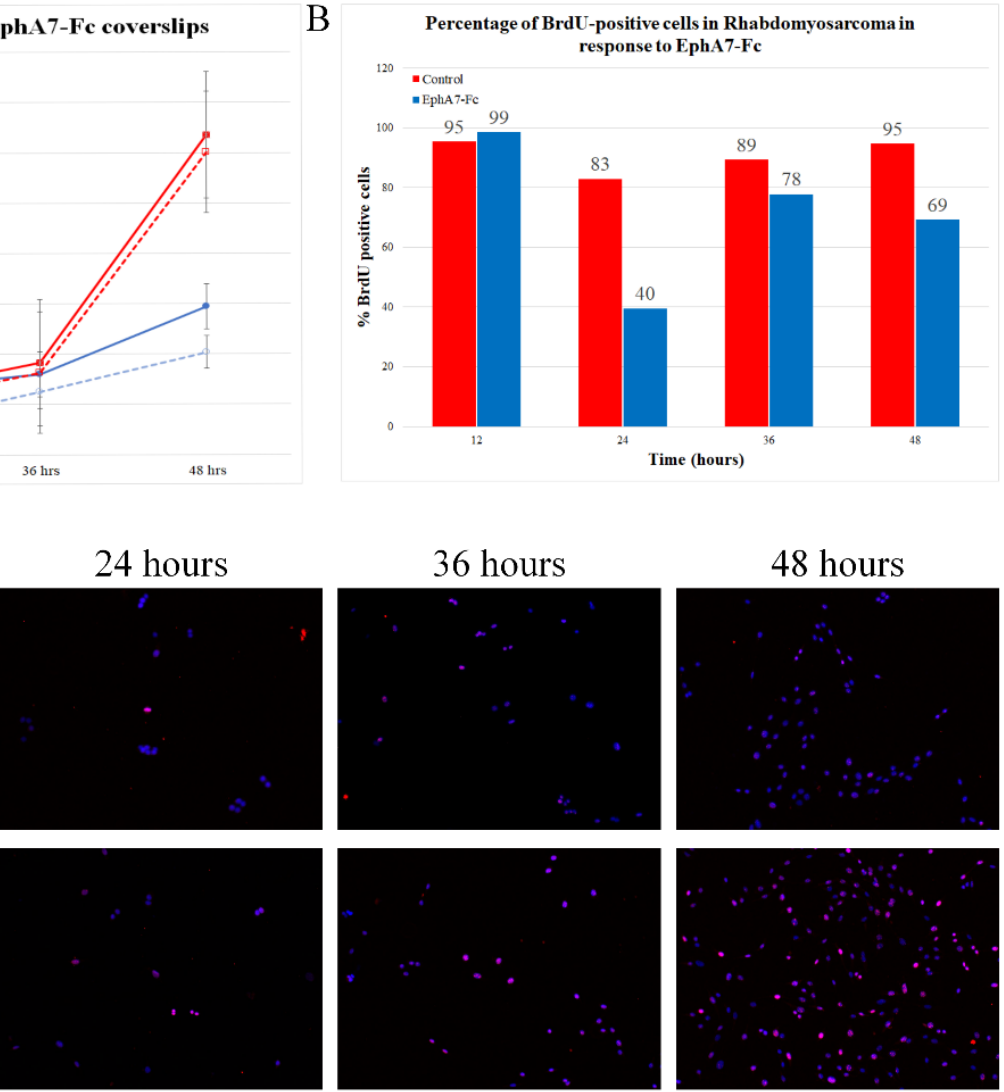

Figure 4-1. RMS cell growth in response to EphA7 treatment. U23674 cells were seeded onto laminin-coated glass coverslips with or without EphA7-Fc chimera protein. To measure cell expansion over time, BrdU was added to the media in four sequential 12hour increments. Cover slips were fixed for 10 minutes in 4\% PFA and stained for DAPI (blue) and BrdU (red). The total number as well as the number of BrdU positive nuclei were counted (A) and the percentage of BrdU positive cells in treated (blue bars) versus untreated (red bars) samples was calculated. Percentages are labeled above each bar. (C) Representative images from each time point. 


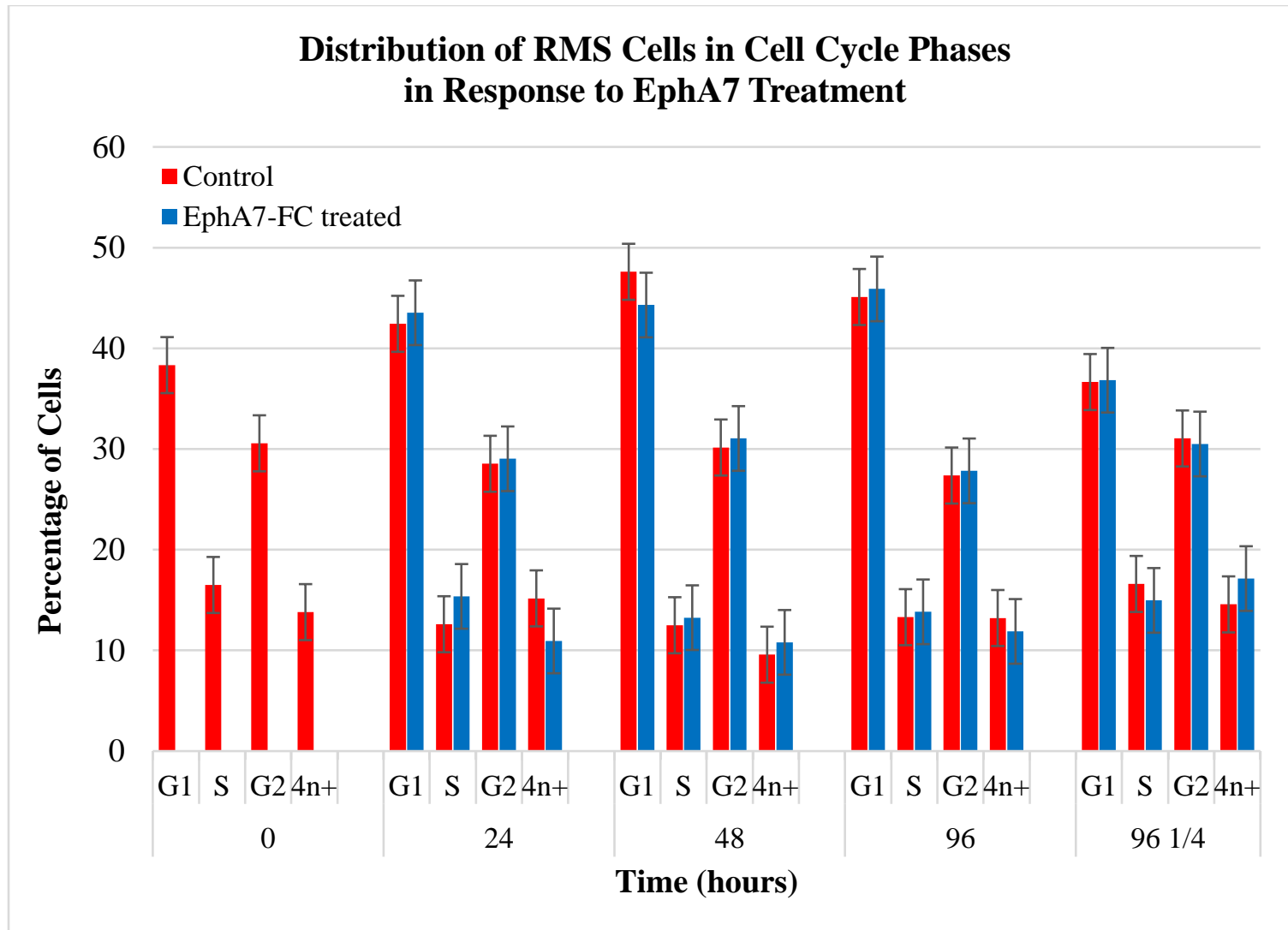

Figure 4-2. Cell cycle analysis of RMS cells treated with EphA7. U23674 cells were grown in gelatin-coated 6-well tissue culture plates with or without EphA7-Fc then harvested and fixed in ice-cold ethanol overnight at $-20^{\circ} \mathrm{C}$. Cells were then stained with propidium iodide and DNA content was analyzed by FACS on a BDAccuri C6 Flow Cytometer. Values are the average of three separate trials and error bars indicate standard error. 

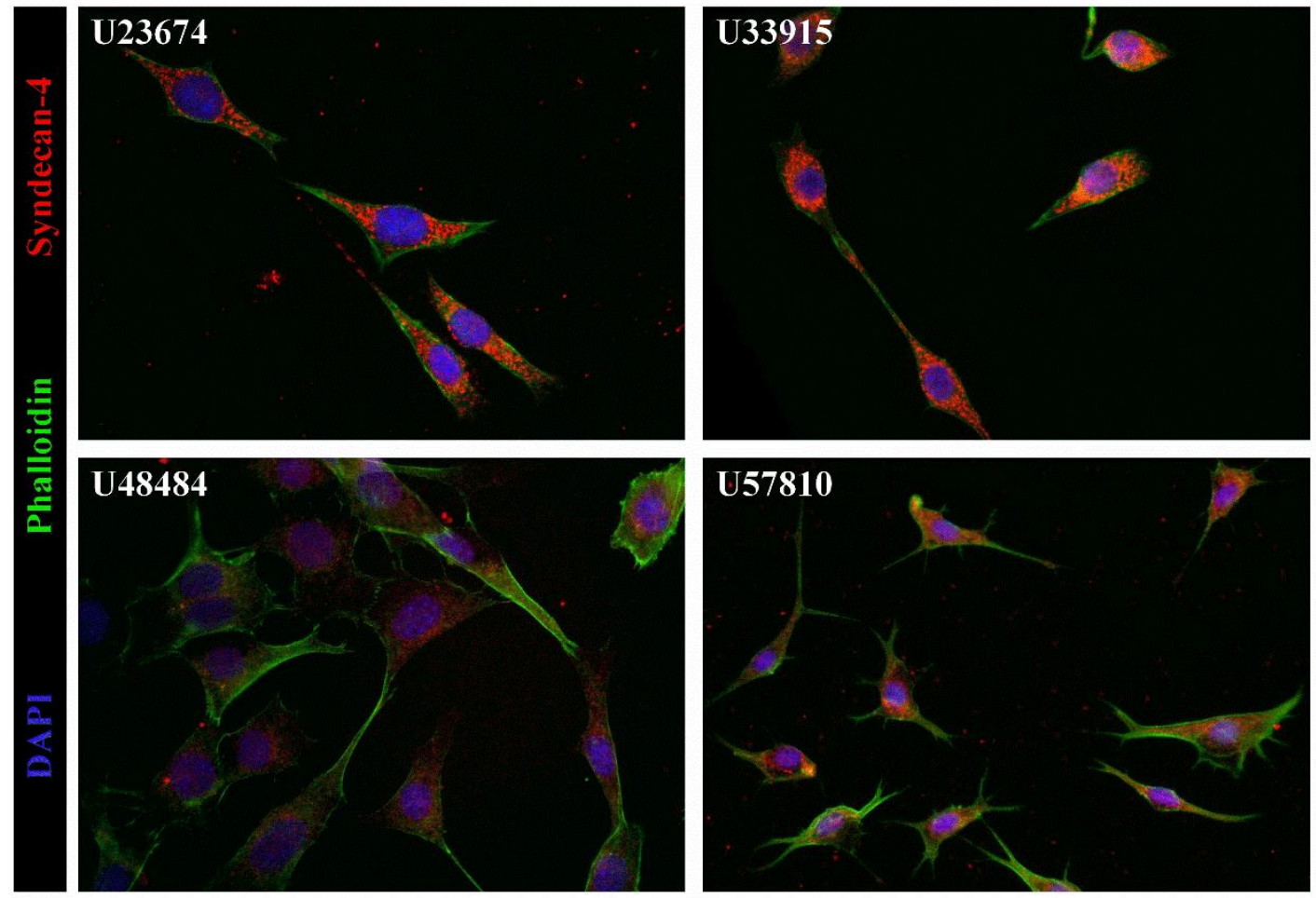

Figure 4-3. Mouse RMS cell lines express satellite cell marker Syndecan-4.

Syndecan-4 expression in was investigated by immunofluorescence in four mouse RMS cell lines: U23674 (ARMS), U33915 (ERMS), U48484 (ARMS), U57810 (ERMS). Cells were grown on glass coverslips coated in gelatin, fixed with 4\% PFA for 10 minutes, and stained for syndecan-4 (Alexa 555, red), F-actin (phalloidin Alexa 488, green), and nuclei (DAPI, blue). Syndecan-4 expression was detected in all four cell lines in a punctate pattern that is typical of transmembrane proteins that are confined to lipid rafts. 


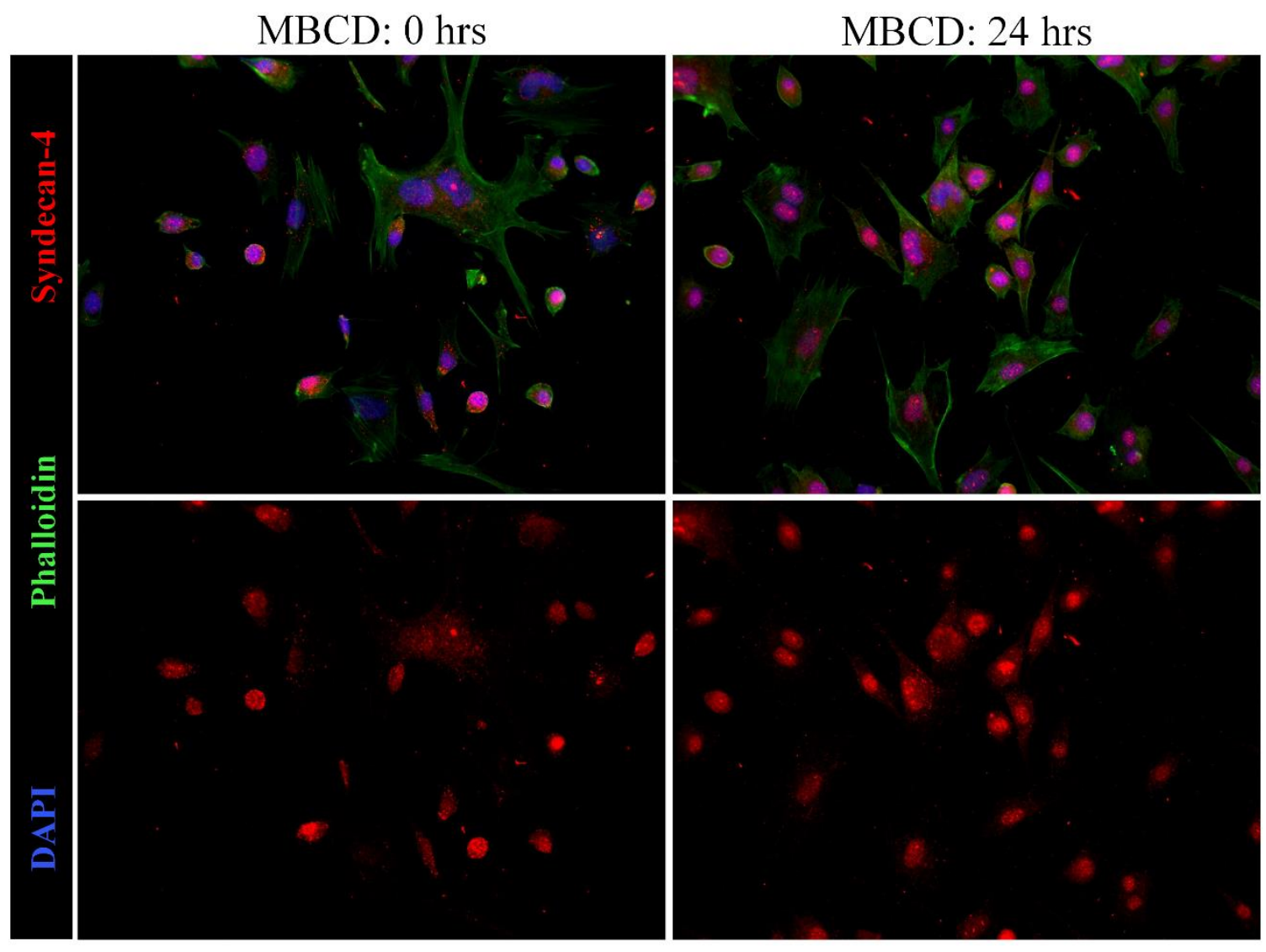

Figure 4-4. Syndecan-4 is in the nucleus after lipid raft disruption.

RMS cell line U23674 was cultured on gelatin-coated coverslips and treated with $2 \%$ methyl- $\beta$-cyclodextrin for 1 hour at $37^{\circ} \mathrm{C}$ in a humidified cell culture incubator. Treated and untreated cells were fixed for 10 minutes in $4 \%$ PFA at $4{ }^{\circ} \mathrm{C}$ then stained for DNA (DAPI, blue), F-actin (phalloidin Alexa 488, green), and syndecan-4 (Alexa 555, red). The top panel includes all three color channels, while the bottom panel is the same image showing only syndecan-4 staining. Methyl- $\beta$-cyclodextrin disrupts lipid rafts, so a loss of punctate syndecan-4 staining is expected after treatment. 


\section{Literature Cited}

1. Holmberg, J., D.L. Clarke, and J. Frisen, Regulation of repulsion versus adhesion by different splice forms of an Eph receptor. Nature, 2000. 408(6809): p. 203-6.

2. $\quad$ Lee, J., et al., Secreted Ephrin Receptor A7 Promotes Somatic Cell Reprogramming by Inducing ERK Activity Reduction. Stem Cell Reports, 2015. 5(4): p. 480-9.

3. Oricchio, E. and H.G. Wendel, Mining the cancer genome uncovers therapeutic activity of EphA7 against lymphoma. Cell Cycle, 2012. 11(6): p. 1076-80.

4. Genander, M. and J. Frisen, Ephrins and Eph receptors in stem cells and cancer. Curr Opin Cell Biol, 2010. 22(5): p. 611-6.

5. Holmberg, J., et al., Ephrin-A2 reverse signaling negatively regulates neural progenitor proliferation and neurogenesis. Genes Dev, 2005. 19(4): p. 462-71.

6. Genander, M., J. Holmberg, and J. Frisen, Ephrins negatively regulate cell proliferation in the epidermis and hair follicle. Stem Cells, 2010. 28(7): p. 1196205.

7. Wang, J., et al., Downregulation of EphA7 by hypermethylation in colorectal cancer. Oncogene, 2005. 24(36): p. 5637-47.

8. Wang, J., et al., Differential expression of EphA7 receptor tyrosine kinase in gastric carcinoma. Hum Pathol, 2007. 38(11): p. 1649-56.

9. $\quad$ Bai, Y.Q., et al., Low EphA7 Expression Correlated with Lymph Node Metastasis and Poor Prognosis of Patients with Esophageal Squamous Cell Carcinoma. Acta Histochem Cytochem, 2015. 48(3): p. 75-81.

10. Nakanishi, H., et al., ALL1 fusion proteins induce deregulation of EphA7 and ERK phosphorylation in human acute leukemias. Proc Natl Acad Sci U S A, 2007. 104(36): p. 14442-7.

11. Guan, M., et al., Aberrant methylation of EphA7 in human prostate cancer and its relation to clinicopathologic features. Int J Cancer, 2009. 124(1): p. 88-94.

12. Carey, D.J., Syndecans: multifunctional cell-surface co-receptors. Biochem J, 1997. 327 ( Pt 1): p. 1-16.

13. Oh, E.S., A. Woods, and J.R. Couchman, Syndecan-4 proteoglycan regulates the distribution and activity of protein kinase C. J Biol Chem, 1997. 272(13): p. 8133-6.

14. Bass, M.D. and M.J. Humphries, Cytoplasmic interactions of syndecan-4 orchestrate adhesion receptor and growth factor receptor signalling. Biochem J, 2002. 368(Pt 1): p. 1-15.

15. Song, S.J., S.M. Cool, and V. Nurcombe, Regulated expression of syndecan-4 in rat calvaria osteoblasts induced by fibroblast growth factor-2. J Cell Biochem, 2007. 100(2): p. 402-11.

16. Feistritzer, C., et al., Syndecan-4-dependent migration of human eosinophils. Clin Exp Allergy, 2004. 34(5): p. 696-703.

17. Horowitz, A., E. Tkachenko, and M. Simons, Fibroblast growth factor-specific modulation of cellular response by syndecan-4. J Cell Biol, 2002. 157(4): p. 71525. 
18. Cornelison, D.D., et al., Syndecan-3 and syndecan-4 specifically mark skeletal muscle satellite cells and are implicated in satellite cell maintenance and muscle regeneration. Dev Biol, 2001. 239(1): p. 79-94.

19. Cornelison, D.D., et al., Essential and separable roles for Syndecan-3 and Syndecan-4 in skeletal muscle development and regeneration. Genes Dev, 2004. 18(18): p. 2231-6.

20. Fried, J., Flow cytofluorometric analysis of cell cycle distributions using propidium iodide. Properties of the method and mathematical analysis of the data. The Journal of Cell Biology, 1976. 71(1): p. 172-181.

21. Krishan, A., Rapid flow cytofluorometric analysis of mammalian cell cycle by propidium iodide staining. The Journal of Cell Biology, 1975. 66(1): p. 188-193.

22. Longley, R.L., et al., Control of morphology, cytoskeletonand migration by syndecan-4. Journal of Cell Science, 1999. 112: p. 3421-3431.

23. Fuki, I.V., M.E. Meyer, and K.J. Williams, Transmembrane and cytoplasmic domains of syndecan mediate a multi-step endocytic pathway involving detergentinsoluble membrane rafts. Biochem J, 2000. 351 Pt 3: p. 607-12.

24. Ronning, S.B., et al., Syndecan-4 Regulates Muscle Differentiation and Is Internalized from the Plasma Membrane during Myogenesis. PLoS One, 2015. 10(6): p. e0129288. 


\title{
Chapter 5:
}

\section{Concluding Remarks and Future Directions}

\author{
Ronnie LaCombe ${ }^{1}$ and DDW Cornelison ${ }^{1,2}$
}

\footnotetext{
${ }^{1}$ Division of Biological Sciences and Bond Life Sciences Center, University of Missouri, Columbia, MO

${ }^{2}$ to whom correspondence should be addressed
} 


\section{Concluding Remarks}

Rhabdomyosarcoma (RMS) is the most common soft tissue tumor in children, but therapy options are limited to chemotherapy, surgery, and radiation therapy [1]. Chemotherapy and radiation therapy can have severe side effects because they target all proliferating cells whether they are cancerous or not. Development of a targeted therapy that specifically targets RMS cells would increase treatment efficacy and decrease side effects, so identifying druggable targets is of high importance. Due to their role in regulating proliferation and differentiation of developing tissue and stem cells, receptor tyrosine kinases (RTKs) are promising targets for therapy development [2-4].

Ephs are the largest family of RTKs in vertebrates with 14 members. Of those 14, only two have described roles in RMS, leaving a significant gap in the field $[5,6]$. The work presented in this dissertation fills in part of that gap using a multi-species approach by analyzing Eph and ephrin expression in canine primary tumors as well as human and mouse cell lines. In Chapter 2 I show that RMS expresses many Ephs and ephrins. Their expression is similar to primary satellite cells except for EphA1 which is expressed by all RMS cells rather than half and is localized to the nucleus of RMS cells.

\section{EphA1 in the nucleus of RMS cells}

In Chapter 3 I show that EphA1 is in the nucleus as a full-length protein that is potentially phosphorylated. Phosphorylation of Ephs indicates activation, so it might be in the nucleus as an active signal transducer. While RTKs in the nucleus are a well described feature in cancer, no nuclear RTKs have previously been detected in RMS and this is the first time that EphA1 has been detected in the nucleus of any cell type. These 
data identify a novel mode of Eph receptor tyrosine kinase signaling in RMS as well for EphA1 signaling. Two other Ephs are detected in the nucleus - EphA5 in lung cancer and EphB4 in prostate cancer - and both are significantly contributing to tumor progression $[7,8]$. This indicates that nuclear EphA1 could be significantly contributing to RMS formation or progression.

While Ephs and ephrins are transmembrane proteins with tyrosine kinase domains in vertebrates, this is not conserved across all animals. In sponges and ctenophores, Ephs lack a transmembrane domain and tyrosine kinase domain [9]. In addition, ephrins are also not membrane bound as they lack the GPI-anchor or the transmembrane domain. This indicates that they are not membrane bound proteins signaling after cell-to-cell contact [9]. Future work in these two systems might provide new mechanisms for Ephephrin signaling that are independent of tyrosine kinase function and cell-to-cell contact. EphA1 intracellular signaling could parallel these functions, so Eph signaling in sponges and ctenophores should be considered moving forward.

\section{Future directions for determining role of EphA1 in the nucleus of RMS cells}

Technical problems discussed in Chapter 3 limited our ability to determine the functional role of nuclear EphA1 in RMS, so continued work in this area is needed. Knock-out experiments using CRISPR/Cas9 or Double Nickase plasmids from Santa Cruz Biotechnology were unsuccessful. Mouse RMS cell lines were successfully transfected as indicated by expression of a GFP-reporter gene on the CRISPR/Cas9 plasmid or survival after puromycin selection of cells that received the Double Nickase plasmids, but EphA1 expression was still detected by immunofluorescence seven days 
later. Moving forward, designing the guide RNA sequence rather than using a commercially available plasmid might yield more efficient knockout of EphA1.

Alternatively, siRNA knockdown could also be used. After knockout or knockdown of EphA1, assays for proliferation rates and migratory ability could provide insight into the role of EphA1 in RMS cells.

On the opposing side of knock-out experiments to determine function, identification of interacting proteins and nucleotides would identify functions for EphA1 in the nucleus of RMS cells. Chapter 3 discusses the challenges to purification of EphA1 from the nucleus, including inefficient pull-down with the Santa Cruz EphA1 antibody, failure to detect AM-tagged EphA1 in transfected cells, and an incompletely repressed EphA1-myc-His TREx system. RMS cells survived tetracycline-induced expression of EphA1-myc-His, indicating that it is not toxic to cells as EphA1-AM might be.

Increasing the amount of Tet receptor or changing the media for tetracycline-reduced culture media could reduce background levels of inducible EphA1-myc-His, making the TREx inducible expression system more efficient. ChIP-seq and LCMS trials should be repeated after optimization of TREx, and nickel-resin extracts should be sent for protein sequencing to confirm that EphA1-myc-His is expressed in the RMS cell lines. It would also be informative to repeat this in ARMS cells to compare the function of nuclear EphA1 between subtypes.

\section{EphA7 exposure could slow proliferation of mouse RMS cells}

In Chapter 4 we identify EphA7 as a potential differentiation therapy avenue for RMS. Exposure to EphA7-Fc chimera protein reduced total cell number as well as the 
number of BrdU-positive cells, suggesting negative regulation of RMS cells. Cell cycle analysis through propidium iodide staining did not produce results consistent with the BrdU experiment, however. There appeared to be no differences in the distribution of cells throughout the cell cycle. There were differences in how these cells were cultured; the first set of experiments were conducted on RMS cells grown on laminin-coated glass coverslips while the second set were conducted on RMS cells grown on gelatin-coated, plastic 6-well dishes. In addition, the three trials for cell cycle analysis were not true replicates as they were run several weeks apart. This particular experiment should be repeated, running 3 samples for each time point simultaneously. In addition, it should be repeated on ARMS cell line U48484 as it is the fastest growing the four mouse RMS lines. Effects on proliferation rates might be more readily apparent with a faster growing cell line.

\section{Mouse RMS cell lines express syndecan-4}

In Chapter 4 I also identified expression of syndecan-4 in all four mouse RMS cell lines. As it is a marker for skeletal muscle stem cells, this could lend support to the satellite cell RMS cell-of-origin hypothesis. Unexpectedly, when lipid rafts are disrupted syndedan-4 expression appeared in and around the nucleus rather than in punctate patterns at the plasma membrane. While this observation was unexpected, syndecan-4 internalization and nuclear translocation has been identified as an important regulator of

differentiation of muscle cells [10]. It would be interesting to see if extending exposure to a lipid raft disrupting agent affects proliferation rates or differentiation status of RMS cells. If it does, a follow-up experiment combining this and treatment with EphA7-Fc 
could produce interesting results by promoting cell growth arrest and differentiation of RMS cells.

\section{Conclusions}

While it was disappointing to be unable to identify a functional consequence of nuclear EphA1 expression, it is still a promising avenue to pursue and I hope that studies continue after I graduate and leave the lab. As only two other Ephs have published functions in the nucleus, this project is at the frontier of a new axis of Eph signaling. I expect that many more Ephs will be detected in the nucleus of a variety of cancers, and that they will be contributing to tumorigenesis, tumor progression, metastasis, and therapeutic resistance. Given the difference in localization between healthy and cancer cells, there is a strong possibility that they will be used as drug targets for developing new therapeutic interventions. 


\section{$\underline{\text { Literature Cited }}$}

1. Gurney, J.G., et al., Soft Tissue Sarcomas, in Cancer Incidence and Survival among Children and Adolescents: United States SEER Program 1975-1995, L. Ries, et al., Editors. 1999, NIH Pub: Bethesda, MD. p. 111-123.

2. Lemmon, M.A. and J. Schlessinger, Cell signaling by receptor tyrosine kinases. Cell, 2010. 141(7): p. 1117-34.

3. Gschwind, A., O.M. Fischer, and A. Ullrich, The discovery of receptor tyrosine kinases: targets for cancer therapy. Nature Reviews Cancer, 2004. 4: p. 361.

4. Fantl, W.J., D.E. Johnson, and L.T. Williams, Signaling by Receptor Tyrosine Kinases. Annual Review of Biochemistry, 1993. 62: p. 453-481.

5. $\quad$ Clifford, N., et al., The EphA3 receptor is expressed in a subset of rhabdomyosarcoma cell lines and suppresses cell adhesion and migration. J Cell Biochem, 2008. 105(5): p. 1250-9.

6. Aslam, M.I., et al., PDGFRbeta reverses EphB4 signaling in alveolar rhabdomyosarcoma. Proc Natl Acad Sci U S A, 2014.

7. Mertens-Walker, I., et al., EphB4 localises to the nucleus of prostate cancer cells. Exp Cell Res, 2015. 333(1): p. 105-15.

8. Staquicini, F.I., et al., Receptor tyrosine kinase EphA5 is a functional molecular target in human lung cancer. J Biol Chem, 2015. 290(12): p. 7345-59.

9. Krishnan, A., B.M. Degnan, and S.M. Degnan. The first identification of complete Eph-ephrin signalling in ctenophores and sponges reveals a role for neofunctionalization in the emergence of signalling domains. BMC Evolutionary Biology, 2019. 19(1): p. 96

10. Ronning, S.B., et al., Syndecan-4 Regulates Muscle Differentiation and Is Internalized from the Plasma Membrane during Myogenesis. PLoS One, 2015. 10(6): p. e0129288. 


\section{VITA}

I'm a Missouri native born and raised in Lee's Summit, a suburb of Kansas City, and my love of science extends as far back as I can remember. I asked for chemistry sets, microscopes, and telescopes for every birthday and Christmas. My siblings and cousins were also very into science, and as children we would play 'wolf pack' and assign roles such as alpha-wolf. This passion for science was complemented by a love for art as well. I took art and science courses every semester through high school. After graduation, I pursued my undergraduate degree at Truman State University in Kirksville, MO. I started off as a double major in Biology and Art but ended up choosing to solely pursue a Bachelor of Science in Biology with a minor in Spanish. I managed to incorporate my interest in art by working for a Biology professor at Truman, Anne Bergey, to help redesign and draw figures for the introductory biology lab guides. Anne Bergey along with Drs. George Shinn, Brent Buckner, and Diane Janick-Buckner, were major positive influences on my time in the TSU Biology department and encouraged me to pursue a doctoral degree.

After graduating from Truman, I joined the Biological Sciences PhD program at the University of Missouri where I joined the Cornelison lab. The research I conducted over my 6 years in graduate school is summarized in this dissertation, but I also spent a significant amount of time participating in leadership and professional development programs as well as science communication and engagement. Science communication events were the most rewarding experiences of my time as a graduate student, and I am pursuing it as a career post-graduation. 
Outside of my graduate work, I am an avid reader. I have found that taking time to read for fun rather than for study is necessary to keep myself from focusing solely on graduate work. During a graduate degree it is easy to focus on reading literature specific to your field of research. Reading for fun helped feed my constant desire to learn about as much as I can. I also played recreational volleyball through most of my educational career. My time spent playing volleyball taught me valuable skills about working with and leading a team while also providing me a fun way to socialize with friends while staying active.

Throughout my graduate career I have been mentored by many people and was always encouraged to think outside the box to solve problems even if it was risky. I was fortunate to be surrounding by a supportive group of people who were willing to challenge me. In particular, Dr. Lori Eggert, Loriana Sekarski, and Dr. Robin Walker have pushed me to places that I would not have imagined possible. Throughout my PhD they have helped me grow immensely as a researcher, leader, team member, and as a person. I am forever grateful for the life sciences community at the University of Missouri and feel prepared to leave graduate school to pursue my passion of science communication and outreach. 